\title{
ZENTRUM
}

FÜR BIODIVERSITÄT UND NACHHALTIGE LANDNUTZUNG

SEKTION

BIODIVERSITÄT, ÖKOLOGIE UND NATURSCHUTZ

- Centre of Biodiversity and Sustainable Land Use -

SECTION: BIOdIVERSity, ECOLOGY AND NATURE CONSERVATION

\section{DEFINITION OF AREAS WITH HIGH CONSERVATION PRIORITY IN SOUTHERN ECUADOR - AN APPROACH COMBINING SPATIAL AND TEMPORAL PATTERNS OF DEFORESTATION AND HUMAN IMPACT WITH ENDEMIC PLANT DIVERSITY}

\author{
Dissertation zur Erlangung des Doktorgrades der \\ Mathematisch-Naturwissenschaftlichen Fakultäten der \\ Georg-August-Universität Göttingen \\ vorgelegt von \\ Ingeniera \\ Tapia Armijos, María Fernanda \\ aus \\ Loja - Ecuador
}

Göttingen, October, 2015 

Referentin/Referent:

Korreferentin/Korreferent:

Tag der Disputation:
Prof. Dr. Christoph Leuschner

Prof. Dr. Holger Kreft

29.10.2015 

A mi pequeña Isabella, amor de mi vida

A Carlos, mi esposo, mi compañero y amigo

A mi madre, mi ejemplo y apoyo 



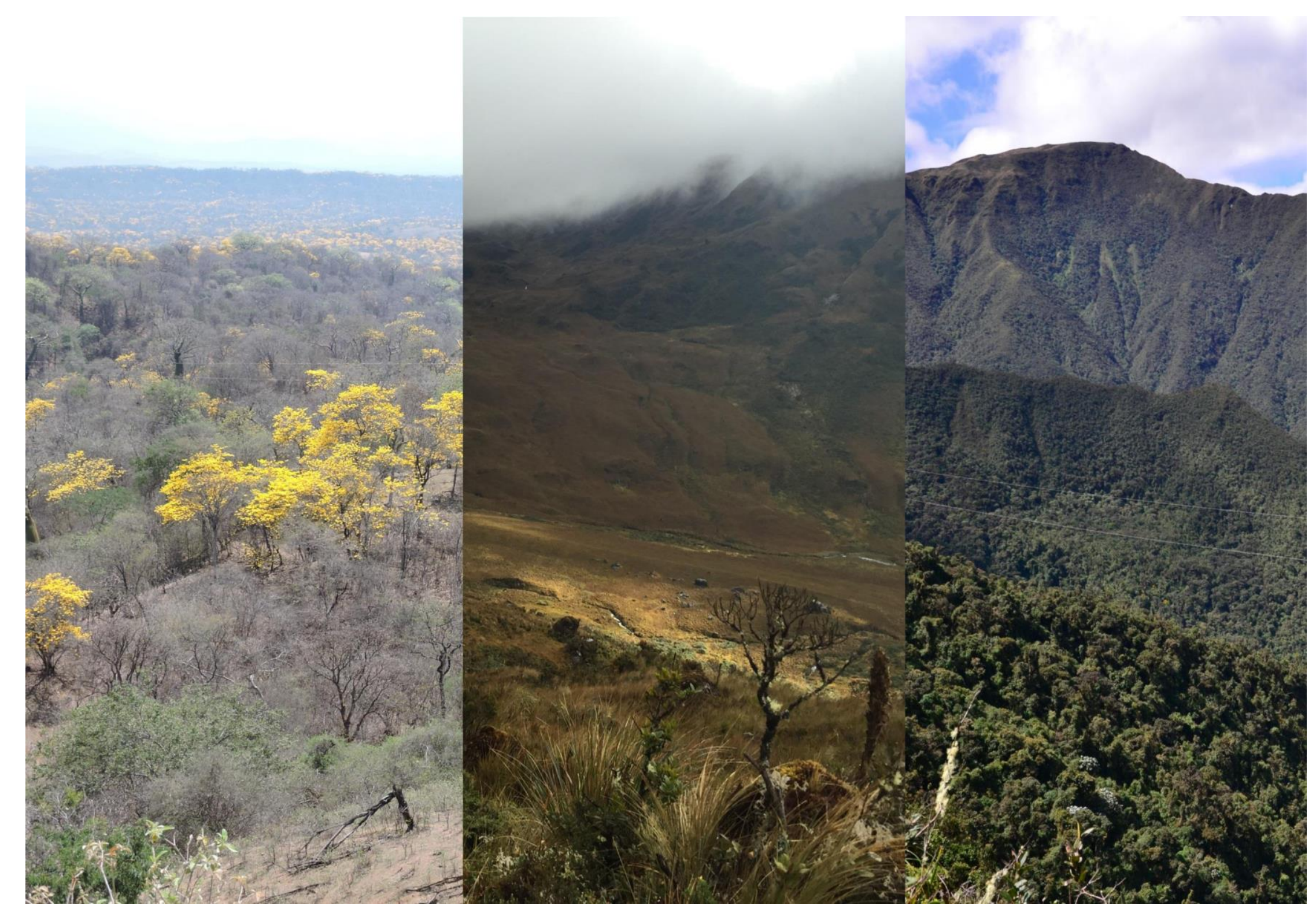





\section{Contents}

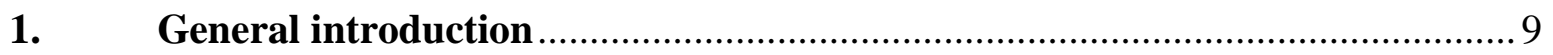

1.1 Global change and the role of Conservation Biology .......................................... 9

1.2 Systematic conservation planning: putting theory into practice ............................. 13

1.2.1 Process of systematic conservation planning .................................................... 14

1.2.2 Core aspects of the process of systematic conservation planning .......................... 15

1.3 Tropical forests: importance of conservation and principal threats....................... 19

1.3.1 Why focus conservation efforts in Ecuador and specifically in South Ecuador? ..21

$1.4 \quad$ Research objectives and outline of chapters ......................................................26

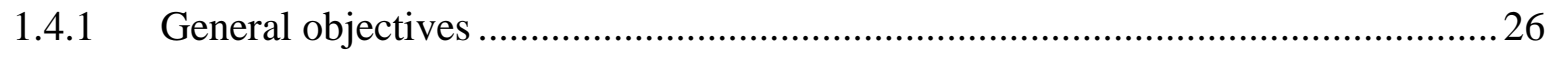

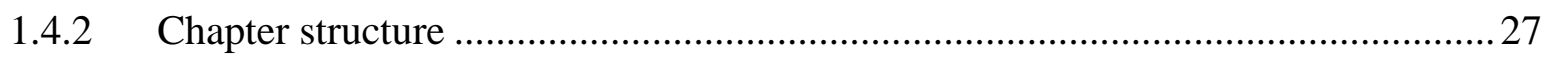

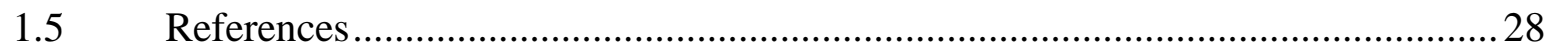

2. Deforestation and forest fragmentation in South Ecuador since the 1970s losing a hotspot of biodiversity .................................................................... 51

$2.1 \quad$ Abstract ................................................................................................... 51

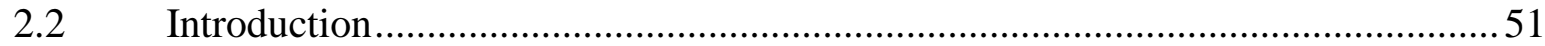

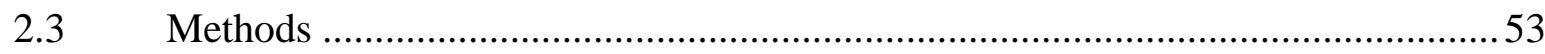

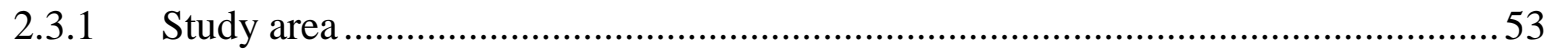

2.3.2 Geographic data........................................................................................54

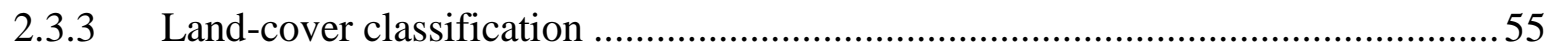

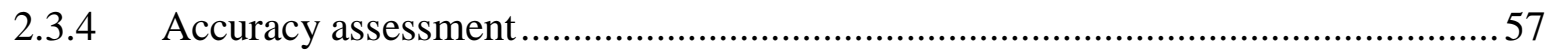

2.3.5 Deforestation at regional level and form the different forest types........................58

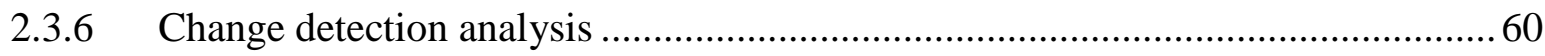

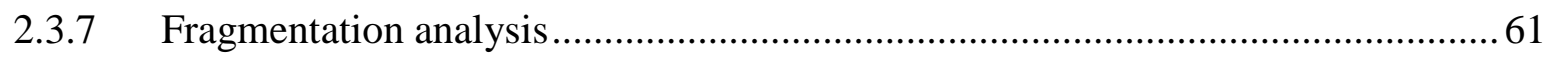

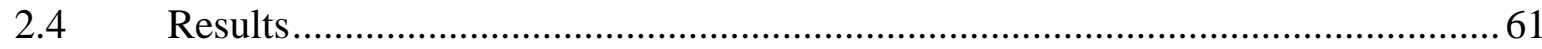

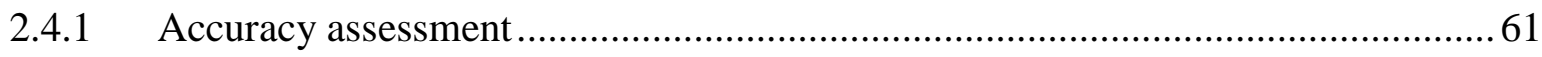

2.4.2 Deforestation and land-cover change patterns ………………………………......62

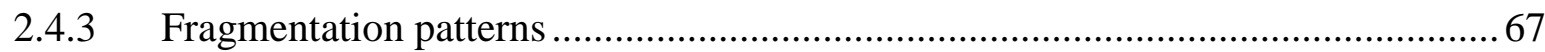

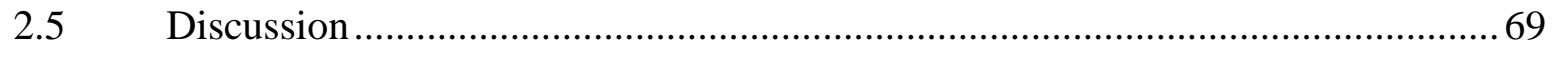




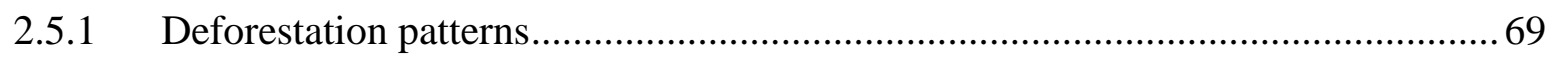

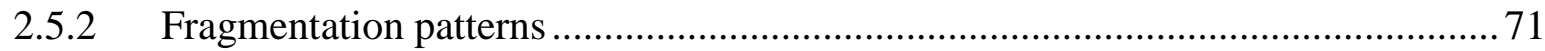

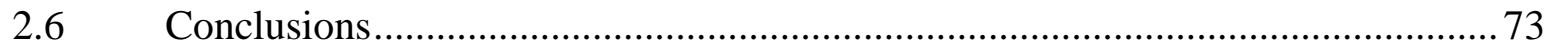

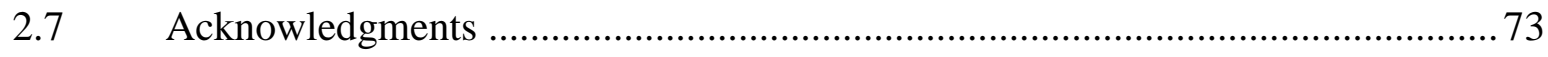

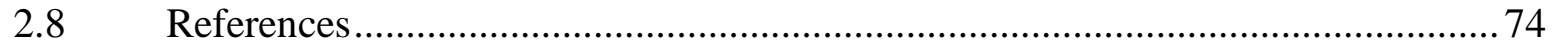

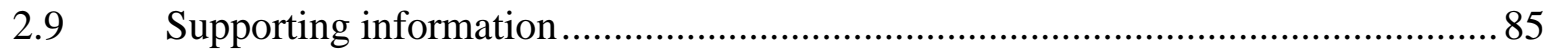

3. Spatio-temporal analysis of the human footprint in South Ecuador: influence of human pressure on ecosystems and effectiveness of protected areas.......... 91

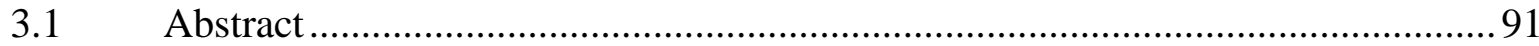

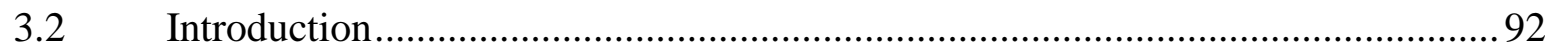

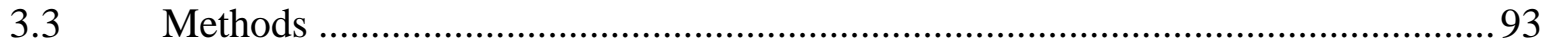

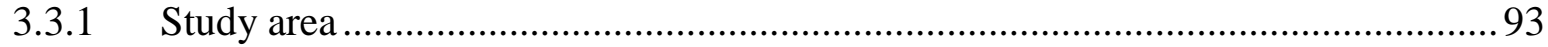

3.3.2 Human footprint map ......................................................................... 95

3.3.3 Human footprint change analysis ........................................................................97

3.3.4 Importance of human footprint inputs...............................................................97

3.3.5 Effectiveness of protected areas ………………………........................................ 98

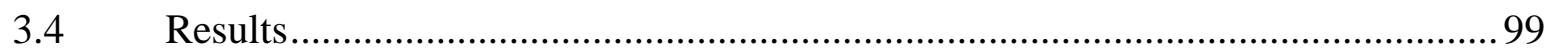

3.4.1 Spatial and temporal changes of Human Footprint ................................................99

3.4.2 Human impact on different vegetation types ………………………………....... 104

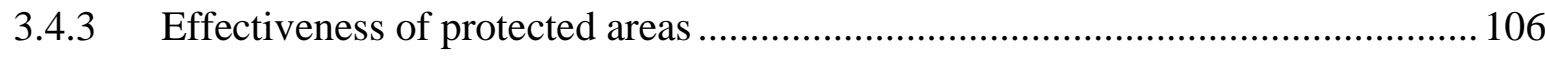

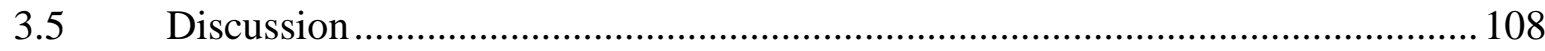

3.5.1 Patterns of human footprint in South Ecuador ...................................................... 108

3.5.2 Patterns of human footprint in the different vegetation types ............................... 111

3.5.3 Effectiveness of protected areas ................................................................ 112

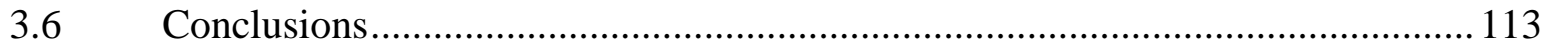

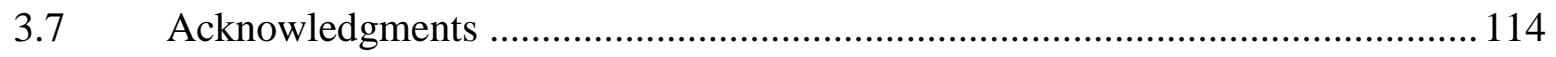

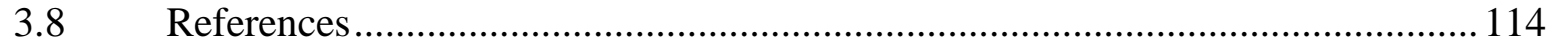

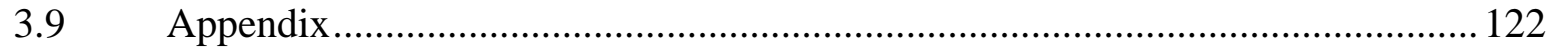

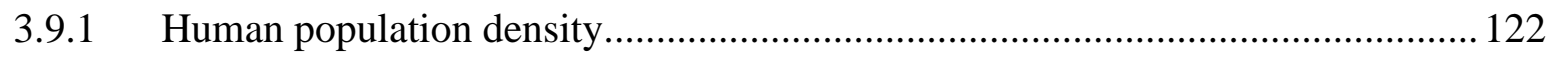

3.9.2 Land transformation .............................................................................. 122

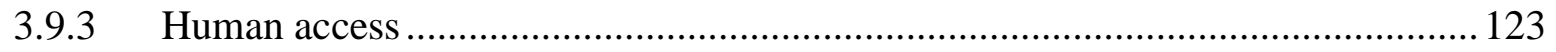


3.9.4 Power infrastructure ......................................................................... 123

4. Is alpha diversity enough to prioritize areas for conservation in Tropical regions? - A case study in Continental Ecuador ............................................127

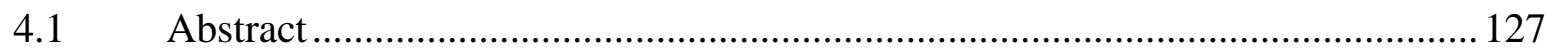

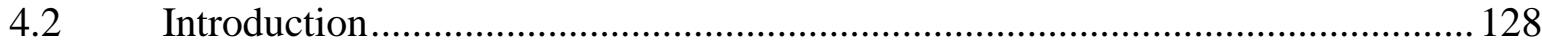

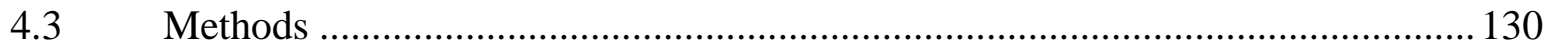

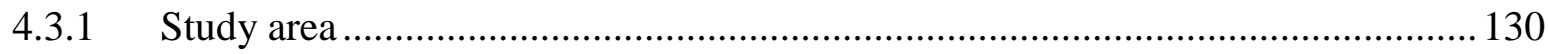

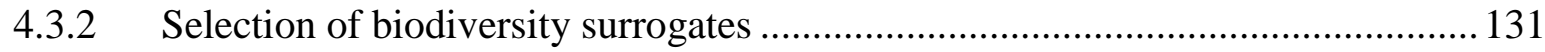

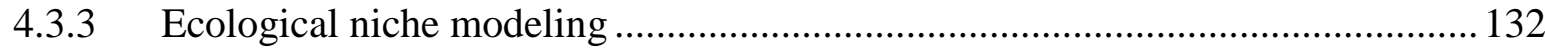

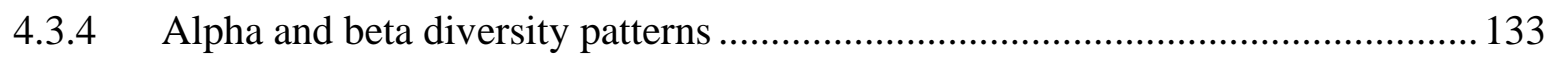

4.3.5 Analysis of alpha and beta patterns of biodiversity ....................................... 134

4.3.6 Identification of conservation gaps and priority conservation areas ................... 134

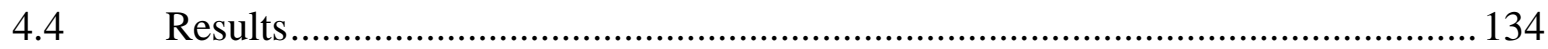

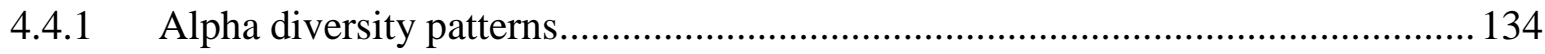

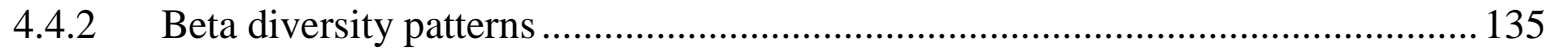

4.4.3 Congruence of patterns of alpha and beta diversity ....................................... 136

4.4.4 Identification of conservation gaps and potential areas for conservation ........... 138

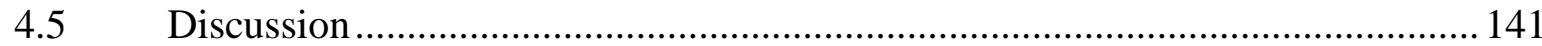

4.5.1 Underlying causes of the observed alpha and beta diversity patterns ................ 141

4.5.2 Observed diversity patterns compared to other studies.................................. 142

4.5.3 Potential conservation areas in the context of conservation planning................. 143

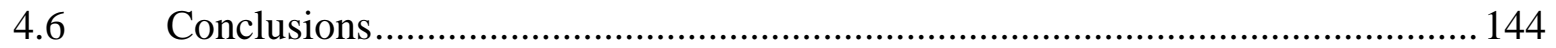

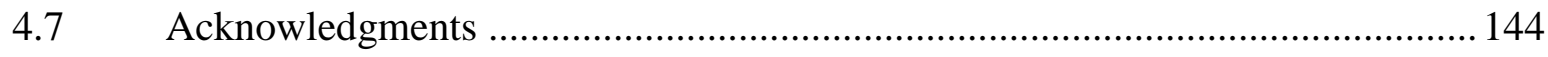

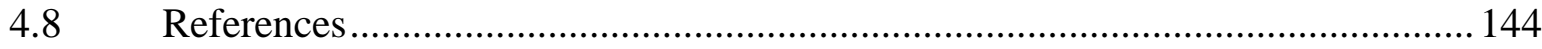

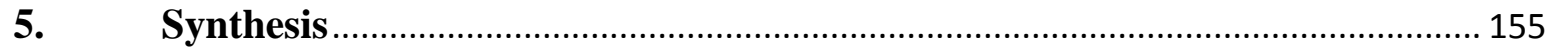

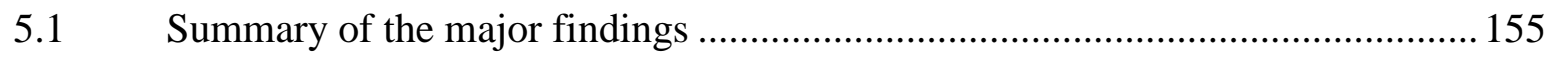

5.1.1 Deforestation, fragmentation, and human pressure dynamics in South Ecuador. 155

5.1.2 Alpha and beta diversity of endemic plant species ...................................... 156

5.2 Implication of the research findings in the context of conservation planning at

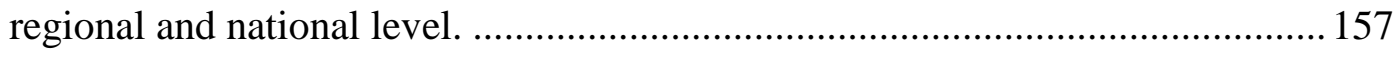

5.3 Propose of new areas of conservation for South Ecuador ............................... 158 
5.4 Limitation of this research and future perspectives .................................... 159

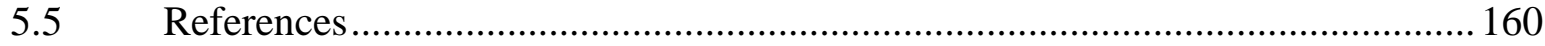




\section{Tables}

Table 2.1 Description of the natural vegetation categories used in this study, combining the vegetation classifications proposed for South Ecuador by Balslev \& Øllgaard (2002),

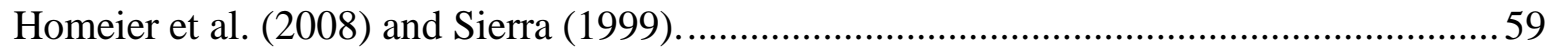

Table 2.2 Confusion matrix obtained from the accuracy assessment of the 2008 land cover map of South Ecuador.

Table 2.3 Area covered by different natural forest types, other covers (non-natural covers) and clouds in 1976, 1989 and 2008 in South Ecuador.

Table 2.4 Changes of natural vegetation types to other covers in South Ecuador since 1976 to 2008 . 66

Table 2.5 Changes in the spatial configuration of natural forests in South Ecuador during the period from 1976 to 2008. 69

Table 3.1 Geographical datasets used to map Human Footprint in South Ecuador. .96

Table 3.2 The correlation coefficients $\left(R^{2}\right)$ between the observed HF values in the five natural vegetation types and the human proxies analyzed. 104

Table 4.1 Extent of potential high-diversity areas, remaining potential protection areas and proportion of currently protected areas.

138

Table 4.2 Extent of diversity categories under the different conservation categories in the PANE. 


\section{Figures}

Figure 1.1 Conservation Biology's general framework... ……………………………..... 11

Figure 1.2 Stages of systematic conservation planning …………………....................... 15

Figure 1.3 Elevational gradient and distribution of forest, degraded areas and protected

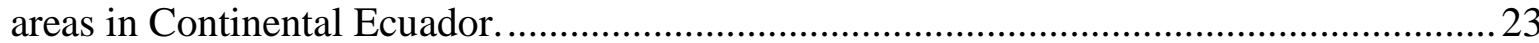

Figure 1.4 Elevational gradient in South Ecuador and description of the Amotape -

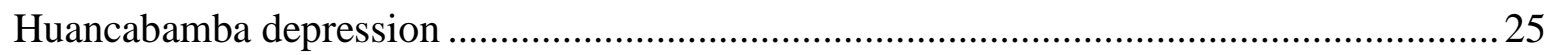

Figure 2.1 Distribution of the main natural vegetation categories in the Loja and Zamora Chinchipe Provinces in South Ecuador 54

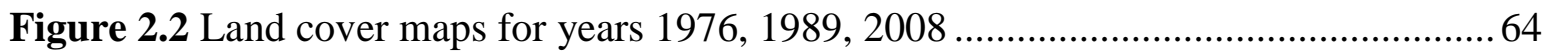

Figure 2.3 Annual deforestation rates for different vegetation types in South Ecuador .....65

Figure 2.4 Variation of forest fragment size and total fragment area for 1976, 1989 and 2008 .68

Figure 3.1 Location of the study area and distribution of the principal vegetation types in the southernmost Ecuadorian provinces of Loja and Zamora Chinchipe .94

Figure 3.2 The conceptual model to evaluate the effectiveness of the Podocarpus National Park in South Ecuador. .99

Figure 3.3 Spatial and temporal change of patterns of human pressure in South Ecuador. 100

Figure 3.4 Contribution of the four different categories of human pressure to the total study area in each of the three study years 101

Figure 3.5 Map of Human Footprint change and "hotspots of change". 103

Figure 3.6 Variation of human footprint in the five vegetation types in South Ecuador during the period from $1982-2008$ 105

Figure 3.7 Variation of human pressure in the different study years within and around Podocarpus National Park (PNP) 107

Figure 4.1 Map of continental Ecuador and its altitudinal zones 131

Figure 4.2 Potential alpha and beta diversity maps for continental Ecuador 136

Figure 4.3 Map showing the areas of high alpha and beta diversity and the overlap of both areas. 137 
Figure 4.4 Location of potential areas of conservation in continental Ecuador with three different levels of conservation priority ....................................................................... 140

Figure 5.1 Potential areas for conservation in South Ecuador............................................ 159 



\section{Acknowledgments}

During the last few years, there have been a number of turning points in my life. When I started this journey I had no idea of the challenges that I would have to face; however, I learned many valuable lessons along the way. I have reached the end of this journey, and I want to thank everyone who at some point helped to make this dream come true.

First, I would like to thank Dr. Jürgen Homeier not only for his academic support but also for his support on a personal level, especially during the difficult times. I will always remember him for his qualities as a human being. I also wish to thank Dr. Christoph Leuschner and Dr. Holger Kreft for accepting to be members of my dissertation committee and their valuable comments.

I am grateful for the financial support from the Deutsche Forschungsgemeinschaft (DFG) Research Unit FOR816, the Secretaría de Educación Superior, Ciencia y Tecnología (SENESCYT) of Ecuador, and the Universidad Particular Técnica de Loja (UTPL).

Special thanks to Dr. David Draper Munt for his scientific and technical support and for encouraging me to believe that the road was not that long. I also want to thank Dr. Carlos Iván Espinosa for trusting and believing in me, for always have good ideas when mine did not flow, and also for giving me the freedom to do what I like.

My gratitude to my colleagues in the Departamento de Ciencias Naturales who encouraged me and shared with me their scientific knowledge and daily experiences. Thanks to Carlitos, Andrea, Yadi, Vero, Augusta, Itziar, and Diego.

Many thanks also to my friends with whom I have shared many beautiful moments in Göttingen: Nele, Siria, Angi, Pablo, Marco, Renee, Edison, and especially Andrea for being more than a friend to my family and me.

Finally, I want to thank those important people in my life, my friends, and family. Yadira, Elvia, Cecilia, Andrea and Mónica, I always carry you in my heart, and I still remember the

first time I went to Germany and you were there giving me strength. Thanks Augusta, 
through your advice I found my way, and your phrase "a way of seeing" is perhaps the best advice that I received. To my family, the most important people in my life. Thank you mom, you have been my best example of perseverance and effort. Thanks Carlos for being my partner, for sharing and living this dream with me, and thanks to my little princess Isabella who came into my life when I was beginning this stage and even though this has required a great sacrifice by both of us, having you always beside me has given me the strength to continue. 


\section{Summary}

The forests of South Ecuador have high conservation value because they are highly threatened, but also possess high diversity and endemism levels. However, as the process of conservation is inherently spatial, the little available information about the factors that promote vulnerability of these forests as well as the spatial distribution of the conservation targets have produced some conservation pitfalls. The main objective of this dissertation was to generate spatial information about the threats and biological values occurring in this region to prioritize areas for conservation.

The second chapter analyzes the deforestation and fragmentation patterns in the region since the 1970s using aerial photographs and satellite images to identify areas with remaining forest, fronts of deforestation, annual deforestation rates and the dynamics in the composition and configuration of the landscape of South Ecuador. We recorded annual deforestation rates of $0.75 \%(1976-1989)$ and $2.86 \%(1989-2008)$ for two consecutive survey periods. Also, we found that South Ecuador is experiencing an ongoing fragmentation process due to an increase in the number of patches, a decrease in mean patch size and an increase in the isolation of forest fragments. This study also contributes to a better understanding of forest change dynamics in the tropics. We found that substantial portions of natural forests are being degraded or converted into pastures and that main fronts of deforestation are located in the lowest areas in the premontane evergreen forest.

The third chapter describes the temporal and spatial patterns of human pressure, as it is one of the main factors that influence the effectiveness of conservation strategies. At local scale, we adapted at local scale the Human Footprint Index (HF) developed by Sanderson et al. (2002), to evaluate spatial changes in HF during a 26 year period at both landscape and ecosystem levels. This information allowed us to identify "hotspots of change" and the wildest areas remaining in order to evaluate how different human proxies contribute to HF and to demonstrate how effective the most important protected areas have been in reducing human pressure inside and outside their boundaries. The findings show a noticeable 
increase in human pressure levels in South Ecuador and a progressive reduction in the wildest areas. We also identified that the important "hotspots of changes" are located in the western region and the Rio Zamora river basin. The most impacted vegetation types were seasonally dry forest and shrubland. Here, population density is the human proxy with the highest contribution to the observed patterns. Finally, we found that Podocarpus National Park has been partially effective in reducing human pressure inside and outside its borders. HF levels have increased inside and outside the boundaries of the protected area, but the human pressure was always lower than that observed in the surrounding landscape.

The fourth chapter analyzes the patterns of alpha and beta diversity of endemic plant species to evaluate the congruence of both patterns and to identify areas with the highest diversity of endemic plants in order to prioritize areas for conservation. We found that hotspots of alpha diversity are concentrated along the Andes, but this diversity was only slightly congruent with beta diversity patterns of endemic plants mostly concentrated in the western and eastern escarpments of the Andes, and in the Coastal and Amazon cordilleras. We also found that approximately $40 \%$ of the areas with the highest alpha and beta diversities have already disappeared due to deforestation and that only $30 \%$ is under protection in Ecuador. Thus, we propose 12 potential areas with a high priority of conservation mostly located in South Ecuador to improve the representativeness and complementarity of the current reserve network.

Finally, the fifth chapter synthesizes the principal findings of this thesis highlighting the implications for conservation and suggesting potential areas to be preserved based on human pressure levels, remaining forest and alpha and beta diversity patterns of endemic plants. 


\section{Resumen}

Los bosques del Sur del Ecuador tienen un alto valor para la conservación puesto que están muy amenazados pero también poseen altos niveles de biodiversidad y endemismo. Sin embargo, como el proceso de conservación es inherentemente espacial, la baja disponibilidad de información espacial acerca de los factores que promueven la vulnerabilidad de estos bosques y acerca de la distribución espacial de los objetivos de conservación ha provocado varios obstáculos para la conservación de los mismos. El objetivo principal de esta tesis fue generar información espacial acerca de las amenazas y los valores biológicos que ocurren en esta región para priorizar áreas de conservación.

El segundo capítulo analizó los patrones de deforestación y fragmentación en la región desde 1976 usando fotografías aéreas e imágenes satelitales para identificar las áreas de bosque remanente, los frentes de deforestación, las tasas anuales de deforestación y las dinámicas de la composición y configuración del paisaje del Sur del Ecuador. Se registraron tasas anuales de deforestación de 0.75\% (1976 - 1989) y 2.86\% para dos periodos consecutivos. Se encontró también que el Sur del Ecuador está bajo un creciente proceso de fragmentación debido al incremento en el número de parches, el decremento en el tamaño promedio de los parches y el incremento en el aislamiento de los parches. Este estudió también contribuyó al mejor entendimiento de las dinámicas de cambio de los bosques tropicales. Se registró que la mayor superficie de bosque natural fue degradado o convertido a pastizales y que los principales frentes de deforestación están localizados en las zonas de bajas altitudes en los bosques siempreverdes premontanos.

El tercer capítulo describe los patrones espaciales y temporales de la presión humana, debido a que este es uno de los principales factores que influencian la efectividad de las estrategias de conservación. Para esto se adaptó el Índice de Impacto Humano (HF) generado por Sanderson et al. (2002) y así evaluar los cambios espaciales en el HF durante 26 años a nivel de paisaje y de ecosistema. Esta información permitió identificar algunos "hotspots de cambio" y las áreas con menor influencia para de esta forma evaluar como los 
diferentes factores humanos contribuyen al HF y demostrar cuan efectiva ha sido el área protegida más importante de la región para reducir la presión humana al interior y exterior de sus límites. Los resultados muestran un notable incremento en los niveles de presión humana en el Sur del Ecuador y un decremento en el número de áreas sin influencia. Se identificó también que uno de los más importantes "hotspots de cambio" está localizado en la región occidental del área de estudio y en la cuenca baja del Río Zamora. Los tipos de vegetación con mayor influencia humana fueron los bosques secos estacionales y los matorrales en donde la densidad de la población fue el principal factor humano que contribuyó a los niveles de presión humana observados. Finalmente, se encontró que el Parque Nacional Podocarpus ha sido parcialmente efectivo para reducir la presión humana en su interior y exterior, puesto que los niveles de HF se incrementaron al interior del área protegida y en el área buffer pero fueron menores a los observados en las áreas circundantes.

El cuarto capítulo analizó los patrones de diversidad alfa y beta de plantas endémicas para evaluar la congruencia entre ambos patrones e identificar áreas con prioridad para ser conservadas. Se encontró que el "hotspot" de diversidad alfa para las plantas endémicas está localizado en los Andes y que es poco congruente con las zonas que muestran los más altos niveles de diversidad beta, los cuales están concentrados mayormente en las estribaciones orientales y occidentales de los Andes y en las cordilleras costeras y amazónicas. También se encontró que aproximadamente $40 \%$ de la superficie con altos niveles de diversidad alfa y beta ha desaparecido debido a la deforestación y que solo el $30 \%$ remanente está bajo alguna categoría de conservación. De esta forma se proponen 12 áreas potenciales con alta prioridad para la conservación, las cuales mayormente esta localizadas en el Sur del Ecuador, para de esta forma mejorar la representatividad y complementariedad de la actual red de reservas.

Finalmente, el quinto capítulo analiza los principales hallazgos de esta investigación remarcando las implicaciones para la conservación y sugiriendo áreas potenciales para ser conservadas con base a los niveles de presión humana, vegetación remanente y patrones de diversidad alfa y beta de plantas endémicas en la región Sur del Ecuador. 


\section{CHAPTER 1}

\section{General introduction}





\section{General introduction}

\subsection{Global change and the role of Conservation Biology}

The interactions between humans and ecosystems have been complex since the beginning of civilization, but perhaps they have become more critical over the past century (Steffen et al., 2006). At present, human activities cover approximately three-quarters of the ice-free land on Earth (Ellis and Ramankutty, 2008) showing a clear dominance over natural ecosystems. As a result the Earth has been experiencing a continuous process of global change that in addition to climate change includes land transformation, changes in global biogeochemistry, increased rates of biological invasions and the loss of biological diversity (Vitousek et al., 1997; Walker and Steffen, 1997; Aber et al., 2001; Steffen et al., 2006).

There is extensive literature on the changes in the global system and its drivers and to what extent these are interrelated and synergistic. These studies have shown that the climate has warmed $0.6^{\circ} \mathrm{C}$ over the past 100 years with a higher intensity peak from 1976 onwards (Walther et al., 2002). The increased atmospheric concentration of carbon dioxide, widely recognized as the most important anthropogenic greenhouse gas, is primarily due to the use of fossil fuel and land use/cover change (Nobre et al., 1991; Henderson-Sellers et al., 1993; Wuebbles and Jain, 2001; IPCC, 2007). Land cover change and principally deforestation contribute by not only adding $\mathrm{CO}_{2}$ to the atmosphere but also influencing evapotranspiration rates and eliminating carbon storages (Dickinson and Kennedy, 1992; Henderson-Sellers et al., 1993; Sud et al., 1996; Snyder et al., 2004). At the same time deforestation and more specifically tropical deforestation, is considered one of the principal threats to biodiversity conservation (Myers, 1993; Laurance, 1999; Achard et al., 2002). In fact, none of the 25 global "hotspots" of biodiversity recognized by Myers et al. (2000) retains more than a third of their original habitat (Brooks et al., 2002). Undoubtedly, all these changes are mainly triggered by human pressure.

According to Vitousek (1994), the impact of human pressure on the environment has two mainly fronts: size or population density and the use of resources. In 2015 the world population reached 7.3 billion people, one billion more than the number recorded twelve years earlier (United Nations, 2015). Although the growth rate has slowed, biological 
demand (basic level of resources required per capita) has exceeded the capacity of the biosphere (Ehrlich and Holdren, 1971; Meyer and Turner, 1992). The impact of a higher demand of resources has been felt at various levels, to name just a few examples: a) there is evidence of a strong association between human population density and the loss of carnivore populations at the regional level (Woodroffe, 2000; Cardillo et al., 2004), b) the structure and functioning of estuarine and coastal ecosystems have been altered by the loss of large predators and herbivores as a result of human settlements and extractions in coastal areas (Lotze et al., 2006), c) the distribution patterns of invasive species are highly correlated with human uses, as some species such as the American bullfrog (Lithobates catesbeianus) have a high probability of colonizing new areas associated with high human footprint levels, with severe consequences for native populations (Thuiller et al., 2006; Iñiguez and Morejón, 2012). The consequences of human pressure on biological diversity may be even more severe if we consider that about $20 \%$ of populations live in highly diverse areas where the population growth rates are higher than those observed in the rest of the world (Cincotta et al., 2000).

Immersed in this scenario, Conservation Biology plays a critical and challenging role (Figure 1.1).Conservation Biology emerged as a multidisciplinary science in the mid1980s with the central objective of protecting and preserving biological biodiversity at all levels by evaluating the impacts of human pressures on biological diversity and developing practical approaches to prevent the degradation and extinction of this biodiversity (Soulé, 1985; Meine et al., 2006; Gerber, 2010). 


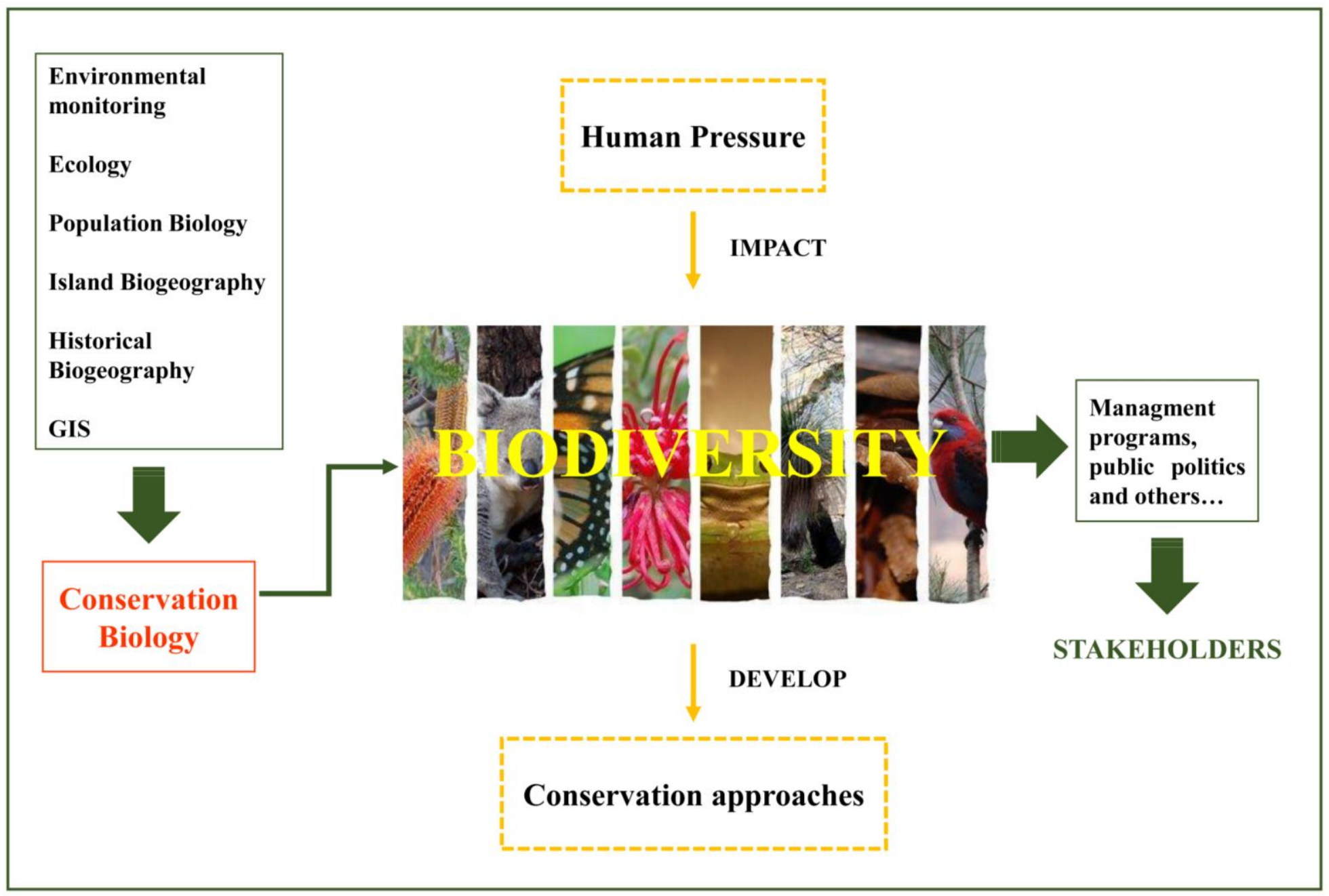

Figure 1.1 Conservation Biology’s general framework that shows how multiple disciplines contribute from their theoretical and practical approaches to this science and how it supports the development of long-term conservation approaches for biodiversity protection. 
Although there have been many theoretical and practical advances in this area during the last thirty years, there is still a long way to go (Balmford and Cowling, 2006). The first challenge is to integrate, in a meaningful way, the human factor in the process of conservation, especially as Conservation Biology faces complex dynamics in which humans have a dominant role (Mascia et al., 2003). For example, today it is necessary to not only design a well-planned reserve network but also understand the human dynamics that revolve around them (about $70 \%$ of protected areas analyzed by DeFries et al. (2005) lost habitat in their surrounding areas increasing isolation between reserves which indicates that although we have sufficient conserved territory it may be inadequate to ensure the maintenance of viable populations). Given this perspective, in addition to theoretical and practical approaches developed thus far, Conservation Biology must include the social factor in the process of conservation to have a greater impact on the process of global change; in fact this can be crucial for the success or failure of conservation actions (Mascia et al., 2003). This involves going from understanding how humans shape the landscape and influence the loss of habitat and biodiversity to how conservation programs impact people and how people can participate actively in these programs.

The second challenge has to do with the time in which we can make decisions and implement programs, as well as to secure the funding for these actions. As Dalerum (2014) recognized, the principal way to reduce global change is related to three key actions: a) reduce human population growth, b) identify alternative economic theories based on the assumption that resources are limited and c) change human values, including the relationship between humans and the environment. However, the same author acknowledged that these are long-term solutions and that the current environmental crisis needs short-term solutions. Regarding of financial resources, these have always been limited, especially in developing countries where only a small percentage of governmental budgets are earmarked for conservation programs (De Oliveira, 2002; Wilson et al., 2007; Dale rum, 2014). Therefore, Conservation Biology needs to be practical by providing timely information to stakeholders, proposing short-term conservation goals and prioritizing conservation efforts (Kareiva and Marvier, 2012). 


\subsection{Systematic conservation planning: putting theory into practice}

In the context of Conservation Biology the process of locating, configuring, implementing and maintaining areas to protect biodiversity and other natural values is known as Conservation Planning (Pressey et al., 2004). Reserve networks have been the cornerstone of conservation strategies (Meir et al., 2004) but in many cases reserves are not a good representation of the biodiversity of a specific area, and many are located in remote, inaccessible and unproductive areas or areas with high levels of human pressure which do not allow the realization of the objectives for which they were created (Pressey et al., 1996; Margules and Pressey, 2000). If we take into account the limited economic resources and that the time in which to respond to the magnitude of global change is limited, we need good prioritization of areas for conservation that maximizes the effectiveness of reserve networks (Groves et al., 2002; Sarkar et al., 2006; Brooks, 2010). This implies that the priority areas meet one or both of the following conditions: 1) they represent or sample the full variety of biodiversity and 2) they separate this biodiversity from processes that threaten its persistence (Margules and Pressey, 2000; Margules et al., 2002; Gaston et al., 2002).

Systematic conservation planning has proven to be an effective strategic framework to achieve the objectives above, given that, as mentioned Margules and Pressey (2000), it is a structured approach which:

- Requires clear choices about the features to be used as surrogates for overall diversity.

- Is based on explicit goals.

- Recognizes the extent to which conservation goals have been met in existing reserves.

- Uses simple explicit models for locating and designing new reserves.

- Applies specific criteria for implementing conservation actions on the ground. 
- Adopts specific objectives and mechanisms for maintaining the conditions within reserves.

\subsubsection{Process of systematic conservation planning}

The process of systematic conservation planning emphasizes the importance of goal-setting from the start as well as the involvement of stakeholders throughout the process (Visconti, 2015). This generally includes several stages (Figure 1.2) from the collection and treatment of biological and social data, selection of features for a quantitative representation of biodiversity, selection of individual areas for conservation, landscape vulnerability analysis, multicriteria selection to fit regional needs, analysis of the available economic resources and the goals proposed by stakeholders to the implementation and evaluation of conservation actions (Knight et al., 2006; Sarkar et al., 2006). Although these different stages do not follow a specific sequence, it is necessary to point out that the process itself is organized into two principal sections: a primary phase in which the identification of priority areas is performed (normally this is a more technical stage, often computer-based) and a secondary phase when the strategy is implemented with the complete participation of stakeholders (Knight et al., 2006).

Systematic conservation planning has been thought to be developed at all planning levels. It has been mostly applied at global and continental scales (e.g. Bibby et al., 1992; Olson and Dinerstein; 1998; Myers, 2000; Fishpool and Evans, 2001; Brooks et al., 2006; Knight et al; 2006) but also at the national level (Rodríguez and Young, 2000; Sierra et al., 2002; Kremen et al., 2008, Laumonier et al., 2010). However, there is a growing need to develop more local approaches. DeFries et al. (2005) mentioned not only the increasing isolation of tropical protected areas, which could have a direct effect on their effectiveness, but also the importance of strengthening the reserve network with complementary protected areas (e.g. private or community areas). This fact means that the process of systematic conservation planning should be adapted to consider as prioritization criteria not only large primary forest areas with high biological value but also small secondary forest areas with high biological value (Barlow et al., 2007; Chazdon et al., 2009). The latter are often private or community areas located in regions with medium or high levels of human pressure creating 
a challenge for conservation planners who must consider local realities and include private owners in the process (Hutton et al., 2005; Gallo et al., 2009; Pasquini et al., 2011).

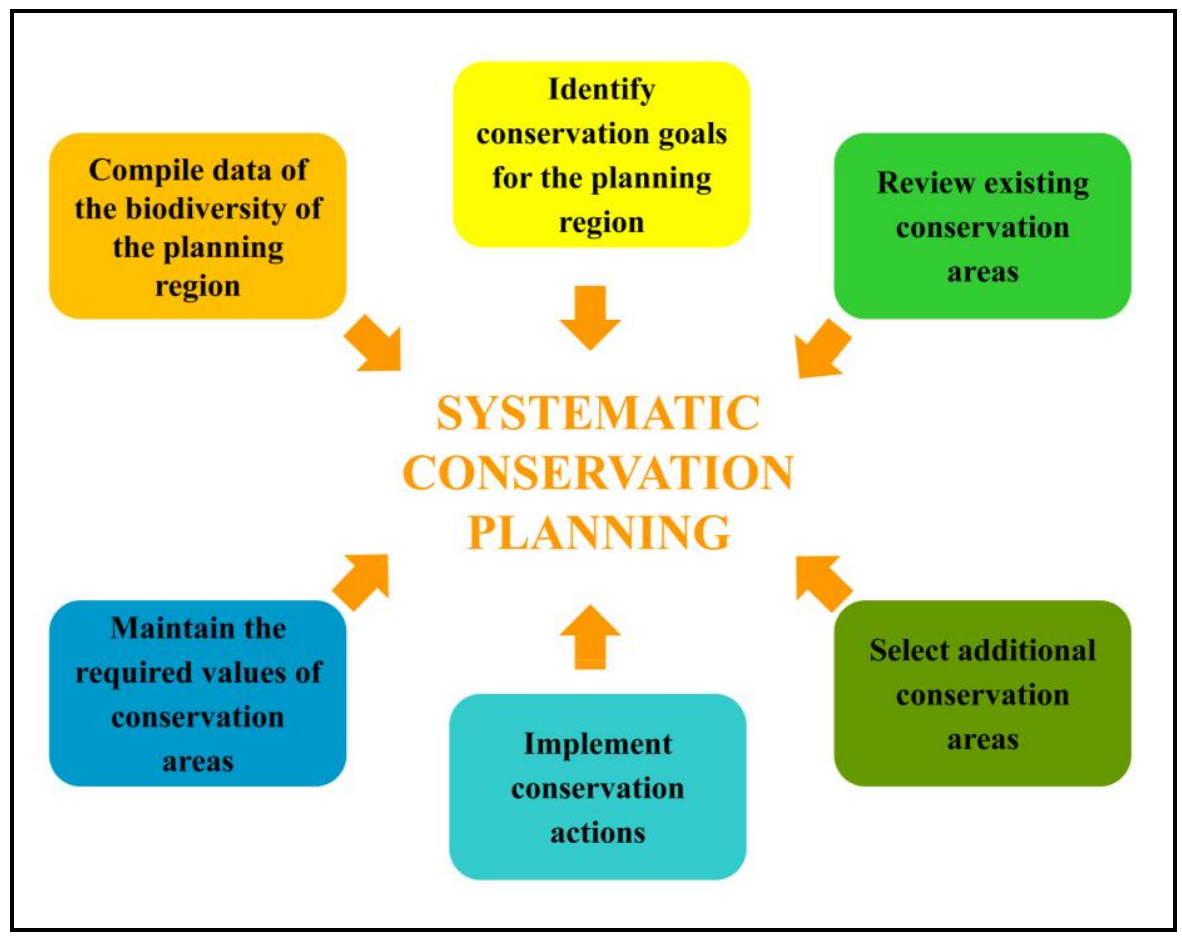

Figure 1.2 Proposed stages of systematic conservation planning according to Margules and Pressey (2000).

\subsubsection{Core aspects of the process of systematic conservation planning}

The different models developed for systematic conservation planning (Margules and Pressey; 2000; Groves et al., 2002; Margules et al., 2002; Cowling and Pressey, 2003; Sarkar and Illoldi-Rangel, 2010) have proven to be quite consistent, although, as mentioned Pressey et al. (1993), some limitations may arise when putting theory into practice. For this reason, it is important to describe some core aspects that must be taken into account when implementing this process.

\section{Selection of conservation target - the role of biodiversity surrogates}

In an ideal world, a comprehensive reserve network is one that includes a portion of every biodiversity feature, but this is practically impossible given our poor knowledge of 
biodiversity (Wilson et al., 2009) and the fact that resources are limited. How many species are there? And where are they distributed? These are questions that conservationist have only been able to respond to in part, a problem called the Linnean and Wallacean shortfall (Whittaker et al., 2005). This limitations has made the selection of specific conservation targets a crucial stage in the process of systematic conservation planning (Redford et al., 2003), through the assumption that focusing planning efforts on these targets increases the probability of conserving more biodiversity (Groves et al., 2002).

When selecting conservation targets the use of biodiversity surrogates has been a common practice (Caro et al., 1999; Margules et al., 2002). Biodiversity surrogates guide the location of reserves assuming at the same time the conservation of unknown biodiversity (Rodrigues and Brooks, 2007). Less time, money and data are therefore required in comparison to the amount of resources needed to obtain multi-species inventory data. Many criteria have been used as surrogates of biodiversity: a) keystone species, b) focal species, c) umbrella species, d) threatened taxa, e) phylogenetic differences, f) assemblages, g) indicator species and $\mathrm{h}$ ) environments, each of them with a different level of efficiency (Margules et al., 2002; Watson et al., 2011). But in general, the use of these criteria must take into account some considerations. The particularities and characteristics of the unknown information can lead us to assume that we are maximizing the level of protection when in reality this is not the case (Favreau et al., 2006). For example, some studies have demonstrated that the presence of one species or taxon rarely correlates with the presence of other species or taxa (Simberloff, 1998). Therefore, to ensure greater effectiveness of this approach Rodrigues and Brooks (2007) suggest: a) the use of cross-taxa as surrogates instead of environmental data, b) the use of taxa with similar characteristics (e.g. taxa that belong to the same realm), and c) the use of extrapolated data instead of field data.

\section{Use of endemic species for conservation prioritization}

The use of an indicator or focal groups to define priority areas of conservation has proven to be an effective biodiversity surrogate (Pearson and Carroll, 1998; Moore et al., 2003). Within indicator groups, endemic species have frequently been used in macroscale studies (Stattersfield, 1998; Olson and Dinerstein, 1998; Myers et al., 2000) and to a lesser extent in regional or local studies (Loyola et al., 2007). 
One of the fundaments of using endemic species as indicator groups in the context of conservation planning is that usually endemic species have narrow distributions and small populations which make them more vulnerable to threats and extinction (Gaston, 1998; Kouki et al., 2001; Myers et al., 2000). Another reason is more concerned with the effectiveness of this indicator, which is based on the results obtained by Lamoreux et al. (2006). Their principal findings indicate that a well-documented group of endemic species may be useful for guiding conservation decisions regarding overall endemism due to the existence of a correlation between endemic taxa. Furthermore, Lamoreux et al. (2006) noted that although many studies have shown that congruence does not exist between the hotspots of species richness and endemism (e.g. Orme et al., 2005) priority sets based on endemic species contain large numbers of species, which increase the effectiveness of use of this group as an indicator. The study of Lamoreux et al. (2006) was carried out on vertebrate taxa, and therefore the correlation in the patterns observed in other taxonomic groups (e.g. plants) may not be the same, and thus more studies are needed.

\section{Use of threatened species for conservation prioritization}

International and national threatened species lists provide an assessment of the risk of extinction, drawing the attention of the general public, conservationists, non-governmental organizations, and decision and policy makers to those species with a high risk in order to promote their conservation (Gärdenfors, 2001; Possingham et al., 2002, Baillie et al., 2004). They are considered to be endangered by some factor (e.g. invasive alien species, habitat loss, over-exploitation) or in most cases by more than one process that often interacts in unpredictable ways (Baillie et al., 2004).

The use of threatened species itself has not been a common practice in conservation prioritization (Brooks et al., 2006). According to Possingham et al. (2002) the fact that red lists usually categorize only well-known taxonomic groups limits their use as biodiversity surrogates. However, the use of threatened species as one of the several factors is strongly recommended (Myers et al., 2000; Groves, 2003; Lamoreux et al., 2006). For example, there have been several studies that have utilized threatened species information with complementary indicators to identify high-risk ecosystems or to do gap analysis (e.g. 
Kiester et al., 1996; Rodrigues et al., 2004; Redding and Mooers, 2006) and others that prioritize areas according to management or conservation needs (e.g. Pärtel et al., 2005).

\section{Vulnerability assessment as a key factor}

Two of the objectives of identifying priority areas for conservation and the establishment of reserve networks per se are to separate biodiversity from processes that threaten its persistence and to mitigate the possible effects that these threats could have on biodiversity (Margules et al., 2002; Wilson et al., 2009). To achieve these objectives, it is necessary to include vulnerability as a factor in the process of systematic conservation planning (Gaston, 2002). Pressey et al. (1994) defined vulnerability as the likelihood or imminence of biodiversity loss caused by current or impending threatening processes. Therefore a natural area and its biodiversity have greater vulnerability when more exposed to stress factors (e.g. Laurance et al. (2002) observed a high correlation between deforested areas and their proximity to roads and population centers). In addition to exposure to a threat, Wilson et al. (2009) mentioned that vulnerability also must include the intensity of a threatening process (magnitude, frequency, and duration) and its impact (response of biodiversity features to the threat), although these factors are more difficult to quantify or represent spatially.

The information on vulnerability is useful at various levels or on multiple occasions of the conservation process. The first, and perhaps most obvious, use is to guide the location of areas for conservation. It is expected that natural areas with high vulnerability are more likely to disappear and therefore must be preserved if its natural value is high (Pressey and Taffs, 2001). However, it is also possible that preserving an area facing a high level of threat could be very expensive, in which case its preservation should be avoided (Game and McDonald-Madden, 2008).

The second important use of vulnerability information is related to the scheduling of priority conservation actions. Scheduling conservation investments are necessary when there are limited resources that prevent the implementation of a reserve network all at once (Pressey and Taffs, 2001). Thus, the areas with high vulnerability must be preserved first since postponing their conservation can involve the loss of their value (Meir et al., 2004), 
whereas the areas with moderate and low levels of vulnerability can be preserved in several stages of investment (Costello and Polasky; 2004; Naidoo et al., 2006; Strange et al., 2006).

Finally, a not well-documented use of vulnerability information is its application to the decision-making process regarding the conservation strategy and type of management for each of the reserves that belong to the network. In areas with minimum levels of human pressure, cataloged by Sanderson et al. (2002) as wild areas, exclusionary conservation approaches may have high effectiveness (Bruner et al., 2001) but in more degraded areas with high vulnerability other forms of conservation, which integrate human populations as management actors, must be adopted (Nepstad et al., 2006; Hansen and DeFries, 2007; DeFries et al., 2007).

\subsection{Tropical forests: importance of conservation and principal threats}

Tropical forests are considered the most ancient and diverse ecosystems on Earth (Myers, 1984). They are home to over half of the planet's biodiversity despite occupying only $7 \%$ of the earth's surface (Wilson, 1988). But their importance goes beyond their biological value, as tropical forests are also home to many ancient indigenous groups (Myers, 1988; Alcorn, 1993; Peres, 1994), provide a great number of environmental services to people who live there (Bishop and Landell-Mills, 2002, Foley et al., 2005), represent pharmacopeias of irreplaceable products (Laurance, 1999), and play a key role in regional climate balance (Shukla et al., 1990).

Despite their importance, they are being cleared, burned, logged, fragmented and overhunted (Laurance and Bierregard, 1997; Laurance, 1999). Hansen et al. (2013) in their last evaluation of forest cover change at the global scale established that although there is a trend toward regeneration and recovery of forests in the world, this is not occurring in tropical areas, where an increase of annual forest loss was registered (an estimated increase of $2101 \mathrm{~km}^{2} /$ year) with a high percentage of this loss concentrated in tropical dry forests (459 $\mathrm{km}^{2} /$ year). As a consequence of deforestation, large areas of tropical forest now exist as scattered patches of variable size immersed in anthropogenic matrices (Hill et al., 2011). 
Areas with large forest patches ( $>100$ ha) can still be found in tropical forests, but often they are surrounded by small fragments ( $<10$ ha) (Laurance et al., 2011; Tapia-Armijos et al., 2015). The effects of patch size, edge effects and loss of connectivity have major consequences for biodiversity (Skole ad Tucker, 1993; Fahrig, 2003; Ewers and Didham, 2006; Hill et al., 2011). For example, Ferraz et al. (2003) reported that half of the original species found in $<100$ ha fragments may disappear within 15 years.

Understanding the factors that are causing the disappearance of tropical forests is a complex task, especially as they vary among regions (Laurance, 1999). Geist and Lambin (2002) classified the drivers of tropical change into two large groups: a) as proximate causes all the immediate actions at the local level that originated from intended land use and that impact direct forest cover (e.g. agricultural expansion, infrastructure expansion, wood extraction), and b) as underlying causes the fundamental social processes that underpin proximate causes (e.g. demographic, economic, technological and cultural factors as well as national and local policies). Among proximate causes, agricultural expansion (cropping, cattle ranching, shifting cultivation and colonization agriculture) is the main trigger for tropical forest conversion (Geist and Lambin, 2002; Hosonuma et al., 2012), whereas economic factors (commercialization and growth of timber markets) and poor policies (e.g. agrarian reforms) are recognized as the principal underlying causes (Laurance, 1999; Geist and Lambin, 2002). However, it is expected that in the coming years population growth will have the same level of importance as the factors mentioned above (DeFries et al., 2010).

Another important factor to consider is that much of the remaining forests are not well preserved, as a large proportion of degraded forests exhibit substantially lower biodiversity values (Wright, 2005, Gibson et al., 2011). One of the principal causes of forest degradation is selective logging, as loggers create internal roads to access high economic value species while allowing the access of hunters and slash-and-burn farmers into previously inaccessible forest areas (Wilke et al., 1992; Bennett, 1999). Selective Logging also contributes to the decrease of species diversity, the loss of functional diversity and changes in forest structure and composition (Johns, 1988; Thiollay, 1992; Brown and Gurevitch, 2004; Ernst et al., 2006). 
The implementation of protected areas is one of the leading strategies for the conservation of tropical forests, but this cannot be the only approach for several reasons. Some studies have shown that protected areas are effective at avoiding deforestation but that the surrounding landscapes of protected areas are being rapidly deforested and degraded (Sánchez-Azofeifa et al., 1999; DeFries et al., 2005; Laurance, et al., 2012). The irreplaceable value of primary forests, many of them protected, for sustaining tropical biodiversity has been recognized (Gibson et al., 2011); but at the same time the value of small patches of secondary forests (Turner and Corlett, 1996; Chazdon et al., 2009), which usually are part of the anthropogenic landscapes surrounding protected areas but are not conserved themselves, has also been recognized. Thus, conservation strategies must be extended to include these areas with some intervention as they are essential for maintaining connectivity between protected areas (Laurance et al., 2012). Another interesting point has to do with the people-free park paradigm, in which some conservationist have argued that human presence must be avoided in protected forests to ensure the protection of biological diversity (Redford and Stearman, 1993; Terborgh, 1999) However, others have highlighted the importance of including people as active actors in the process of conservation, given that almost everywhere on Earth is already under some level of human influence (Schwartzman et al., 2000; West et al., 2006). Tropical conservation itself needs rethinking and finding ways of putting people back into conservation, empowering them to conserve their forests (Pimbert and Pretty, 1995; Schwartzman et al., 2000, Persha, et al., 2011). Protected areas (fully restricted) must remain the cornerstone of conservation strategies, but these should be supported by other conservation actions (e.g. communitarian reserves, private forests, locally protected areas) that are consistent with the current state of tropical forests (Ellis and Porter-Bolland, 2008; Nelson and Chomitz, 2011).

\subsubsection{Why focus conservation efforts in Ecuador and specifically in South Ecuador?}

Ecuador (Figure 1.3A) is one of the most diverse countries on Earth, and it boasts the most diverse per unit area (Jørgensen et al., 1992; Sierra et al., 2002). Situated in the Tropical Andes and Chocó Darien Western Ecuador hotspots (Myers et al., 2000) the country has been ranked first in the number of birds and amphibians, second in reptiles and third in plants per unit area (Sierra et al., 1999). Among plants alone, there are nearly 16000 
vascular species and 4500 endemic species (Jørgensen and León-Yánez, 1999; León-Yánez et al., 2011).

The diversity patterns observed at the continental level have been attributed to several factors that promote highly variable latitudinal and longitudinal gradients. Examples include: a) the presence of the Andes mountain range which crosses the country from north to south giving rise to a high orographic heterogeneity with a variety of ecological niches, and b) the convergence of the Humboldt and El Niño oceanic currents face the Ecuadorian coast, which generates a climatic gradient with humid conditions in the north of the country and more arid conditions in the south (Mittermeier, 1993; Stattersfield et al., 1998).

Following the trend of other countries with outstanding diversity, Ecuador is highly threatened. It is estimated that just over $50 \%$ of the original forest cover has disappeared (Figure 1.3B), ranking Ecuador as one of the South American countries with the least forest cover and the highest deforestation rates (Mosandl et al., 2008). The greatest loss of forest has been recorded on the western side of the Andes (Dodson and Gentry, 1991; Wunder, 2000). In this region, a substantial portion of coastal lowland forest has been converted into agricultural lands, and the remaining northwestern humid forests and southwestern dry forests are being cleared rapidly (Dodson and Gentry, 1991; Sierra, 1999; Sierra and Stallings, 1998; Best and Kessler, 1995; Espinosa et al., 2012). On the eastern side of the Andes there are still extensive areas of forest remaining; however, there are important fronts of deforestation in the northeastern Amazon as a result of oil exploitation and road construction (Pichón, 1997; Sierra, 2000; Messina et al., 2006; Rudel and Horowitz, 2013). Although the effect of forest deforestation and other anthropogenic stressors has not been extensively studied in the country, the decline of some plants, vertebrates, and amphibian species has been reported, and a great number of narrow species have been reported as threatened (Gentry, 1977; Dodson and Gentry, 1991; Downer, 1996; Menéndez-Guerrero and Graham; 2013; Zapata-Ríos, 2009, León-Yánez et al., 2011). 


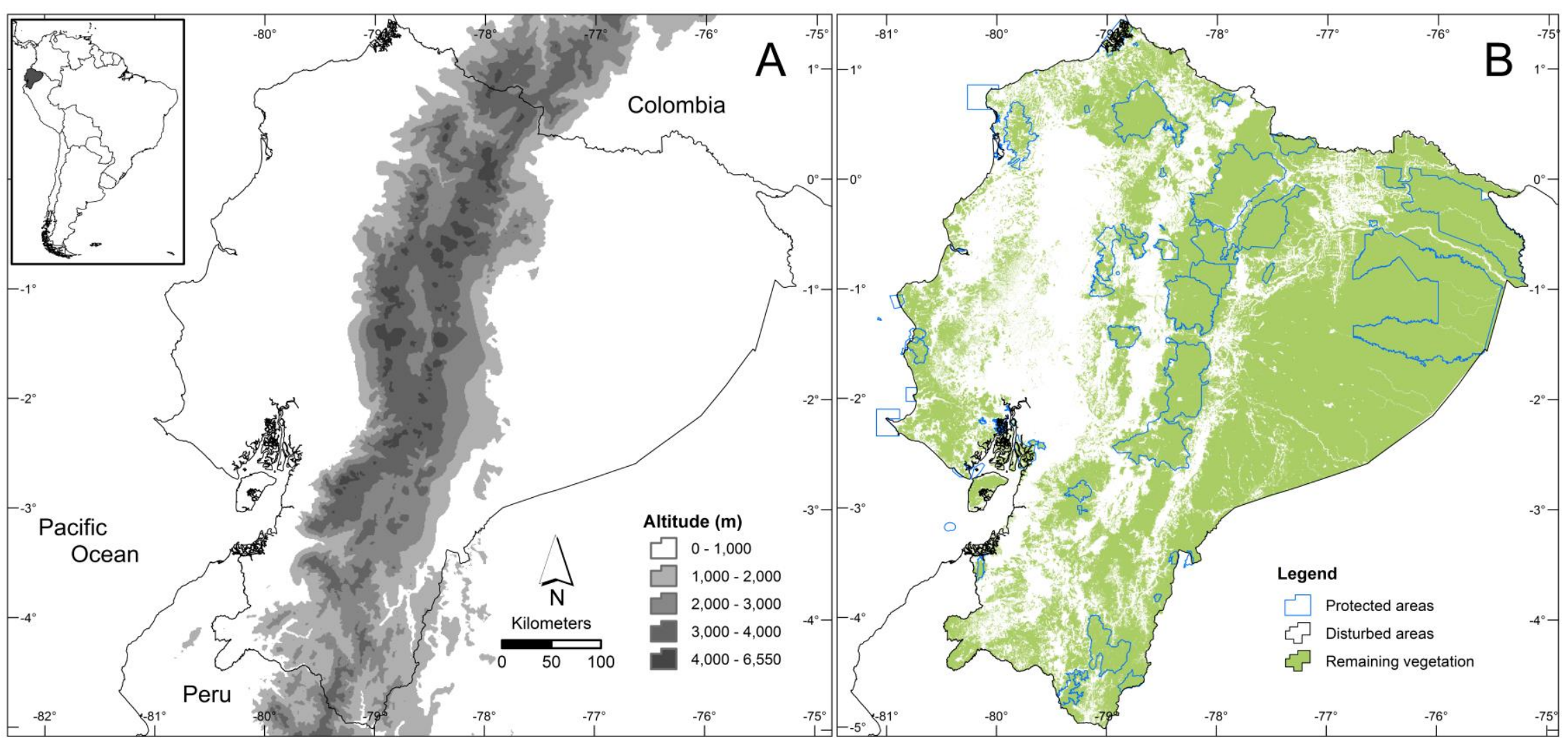

Figure 1.3 A. Map of Continental Ecuador and its elevational gradient. B. Distribution of remaining forest and disturbed areas in Ecuador according to MAE (2012) and location of the national system of protected areas belonging to the PANE System (MAE, 2015). 
Given the high value of Ecuadorian biodiversity and the multiple threats to which it is exposed, urgent conservation actions are needed. Nowadays, approximately $15 \%$ of continental Ecuador is conserved through 48 protected areas (MAE, 2015), making Ecuador one of the countries in Latin America with the most surface area under protection (Elbers, 2011). Nonetheless, some important conservation gaps have been detected in previous studies aimed to prioritize areas of conservation (Sierra et al., 2002; CuestaCamacho et al., 2006; Mateo et al., 2013; Lessmann et al., 2014). These approaches have used ecosystems and taxonomic groups with well-known distribution (birds, plants, mammals and amphibians) as biodiversity surrogates. But for some reason, some areas of high biological value, with a unique and irreplaceability species composition, have not been considered within these proposals. This underscores the importance of additional approaches to achieve greater representation of Ecuadorian biodiversity in the protected areas system or other conservation strategies.

\section{Outstanding aspects of South Ecuador}

While the biodiversity of Ecuador is outstanding, and thus of high conservation value as mentioned above, it is the biodiversity of South Ecuador (Figure 1.4A) which had assumed greater interest in recent years (Young and Reynel, 1997), principally because its flora is quite different from the rest of the country and exhibits a high rate of endemism (Weigend, 2004).

South Ecuador is located in the Amotape-Huancabamba Depression (Figure 1.4B), an area in which the Andes range is partially interrupted by the Rio Chamaya / Río Marañon system and the mountains do not rise as high as those in the North and Central Andes (Weigend, 2002). In this area, the flora of the northern and central Andes overlap, there are a large number of endemic species and genera, and some flora families reach their highest concentrations (Weigend et al., 2005; Richter et al., 2013). There are a couple of reasons for the observed diversity patterns: the Amotape-Huancabamba Depression acts as a biogeographic barrier that promotes speciation, and the irregularity of topographic conditions between ridges and valleys give rise to a variety of microclimates (Lozano, 2002; Weigend, 2002; Richter et al., 2009). 


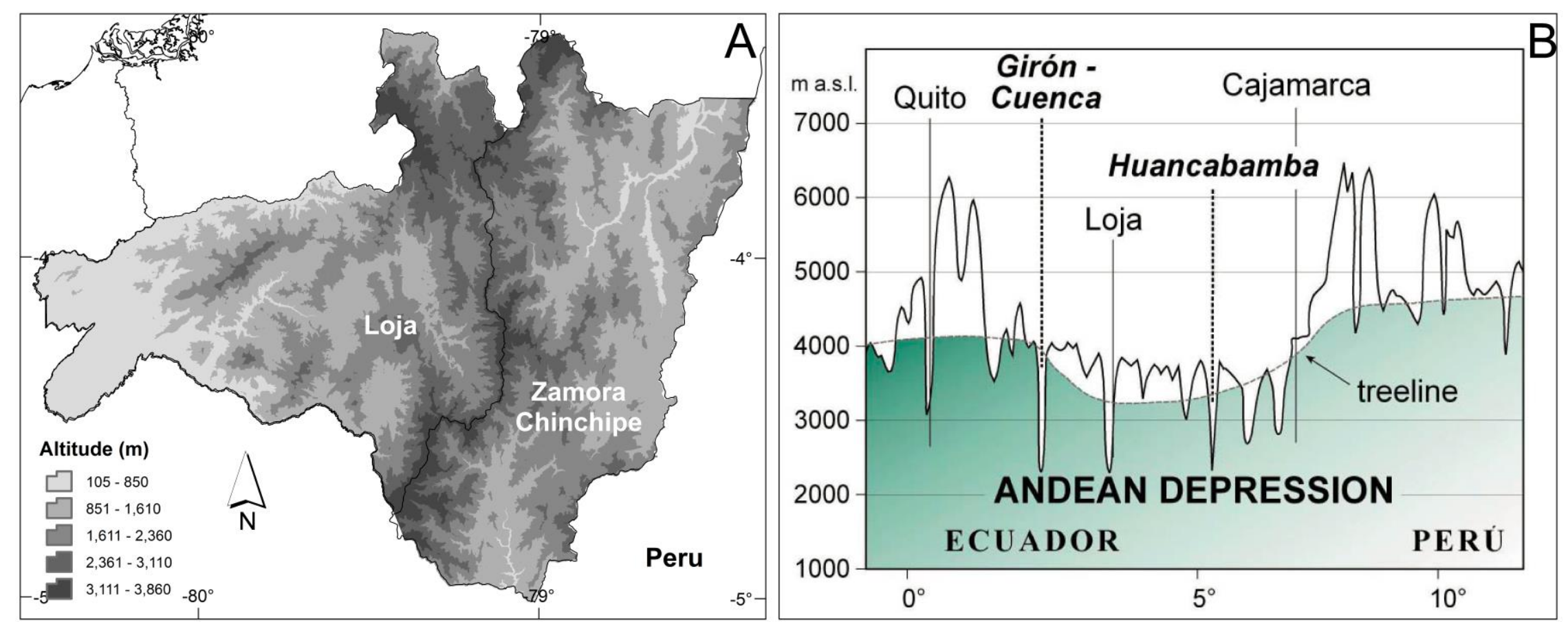

Figure 1.4 A. Elevational gradient in South Ecuador. B. Location and description of the Amotape - Huancabamba Depression (Richter et al., 2009). 
As an example of the biodiversity richness in South Ecuador, a study in a mountain forests in the eastern part of the Cordillera Real found around 1300 seed plants, 250 fern and fern allies, 311 lichens, 21 bats, 227 birds and 2396 moths in only $11 \mathrm{~km}^{2}$ (Richter et al., 2009). According to Lozano (2002) the mountain forests of South Ecuador have proven to be floristically more diverse that those in the north of the country. In the case of the dry forests of South Ecuador, they are part of the Tumbesian region, which is recognized as a center of bird endemism (Davis et al., 1997; Stattersfield et al., 1998; Tinoco, 2009). They are the most continuous and best-conserved remnants in all Ecuador and at the same time the least studied (Neill, 2000; Vásquez and Josse, 2001; Aguirre and Kvist, 2009). Although these forests have a total diversity lower than other dry ecosystems, they rank in plant endemism (Linares-Palomino, 2011).

In South Ecuador, 10\% of the surface is protected by PANE (Ecuadorian protected areas system), with all areas along the eastern escarpments and foothills of the Andes, which has generated significant conservation gaps on the western side where dry ecosystems dominate. It is, therefore, important to generate information in South Ecuador that supports conservation decisions. This will allow greater representation of the unique and rich biodiversity of this area.

\subsection{Research objectives and outline of chapters}

\subsubsection{General objectives}

The main objective of the present study is to increase our knowledge about the biodiversity patterns observed in South Ecuador and the threats to its persistence in order to define priority areas of conservation in this region of high biological value.

In this context, the present study pursues the following specific objectives:

a) To analyze at both landscape and ecosystem levels the land cover changes in South Ecuador since the 1970s with the aim to understand the dynamics of deforestation and 
fragmentation processes as well as current landscape patterns, and to identify remaining forests with potential for in situ conservation and hotspots of deforestation.

b) To describe the evolution of human pressure patterns in the region in order to identify the areas that have the highest and lowest levels of human pressure and to show how geographic tools can be used to evaluate the effectiveness of protected areas in relation to human pressure dynamics.

c) To describe the patterns of alpha and beta diversity of endemic species at the national level in order to identify potential areas for conservation and to highlight the importance of conserving the biodiversity of South Ecuador.

\subsubsection{Chapter structure}

The chapters are presented in sequential order and were prepared as manuscripts for publication in peer-reviewed scientific international journals. The content of each chapter is summarized below.

\section{Chapter II}

The analysis of land cover changes since the 1970s provides the first comprehensive study of land cover dynamics in South Ecuador. It provides information on the annual deforestation rates for two different periods (1976-1989 and 1989-2008) at the regional level and different forest types. This chapter also describes the land cover type into which natural areas were transformed as a first approach to identifying the main drivers of deforestation. Finally, evaluation of the composition and configuration of remaining forests in order to understand the patterns of fragmentation provides useful information about landscape integrity.

\section{Chapter III}

This chapter demonstrates how the footprint index developed at the local scale provides useful information about the dynamics of human pressure in South Ecuador at both regional and ecosystem levels. Analysis of the Human footprint index allows identifying the areas with a high increase of human pressure levels and the wildest areas that may be included 
within reserve networks. Also, this analysis provides a better understanding of the contribution of different human proxies to the levels of human pressure observed and how effective the protected areas are in reducing human pressure, using the emblematic and oldest reserve of South Ecuador as a model.

\section{Chapter IV}

This chapter analyzes the patterns of alpha and beta diversity of threatened endemic species at the national level for first time in order to prioritize areas of conservation. In areas with high environmental heterogeneity, alpha diversity may be insufficient to obtain good representativeness. This chapter also analyzes the conservation gaps for endemic species and proposes new areas to incorporate into the existing network.

\section{Chapter V}

This chapter summarizes the principal findings of the previous chapters highlighting the importance of biodiversity surrogates and vulnerability analysis in the conservation process. This chapter also includes a conservation proposal indicating new areas that must be conserved in South Ecuador taking into consideration alpha and beta diversity, human pressure and landscape integrity. Finally, the chapter details the future perspectives in this type of research.

\subsection{References}

Aber, J., Neilson, R. P., McNulty, S., Lenihan, J. M., Bachelet, D., \& Drapek, R. J. (2001). Forest Processes and Global Environmental Change: Predicting the Effects of Individual and Multiple Stressors We review the effects of several rapidly changing environmental drivers on ecosystem function, discuss interactions among them, and summarize predicted changes in productivity, carbon storage, and water balance. BioScience, 51(9), 735-751. 
Achard, F., Eva, H. D., Stibig, H. J., Mayaux, P., Gallego, J., Richards, T., \& Malingreau, J. P. (2002). Determination of deforestation rates of the world's humid tropical forests. Science, 297(5583), 999-1002.

Aguirre-Mendoza, Z., \& Kvist, L. (2009). Composición florística y estructura de bosques estacionalmente secos en el sur-occidental de Ecuador, provincia de Loja, municipios de Macara y Zapotillo. Arnaldoa, 16(2), 87-99.

Alcorn, J. B. (1993). Indigenous peoples and conservation. Conservation biology, 424-426.

Baillie, J., Hilton-Taylor, C., \& Stuart, S. N. (2004). 2004 IUCN red list of threatened species: a global species assessment. IUCN.

Balmford, A., \& Cowling, R. M. (2006). Fusion or failure? The future of conservation biology. Conservation Biology, 20(3), 692-695.

Barlow, J., Gardner, T. A., Araujo, I. S., Ávila-Pires, T. C., Bonaldo, A. B., Costa, J. E., ... \& Peres, C. A. (2007). Quantifying the biodiversity value of tropical primary, secondary, and plantation forests. Proceedings of the National Academy of Sciences, 104(47), 18555-18560.

Bennett, E. L., \& Gumal, M. T. (2001). The inter-relationships of commercial logging, hunting and wildlife in Sarawak, and recommendations for forest management. The cutting edge: conserving wildlife in logged tropical forest. Columbia University Press, New York, 359-374.

Best, B., \& Kessler, M. (1995). Biodiversity and conservation in Tumbesian Ecuador and Peru (Vol. 218). Cambridge, England: BirdLife International.

Bibby, C. J., Collar, N. J., Crosby, M. J., Heath, M. F., Imboden, C., Johnson, T. H., ... \& Thirgood, S. J. (1992). Putting biodiversity on the map: priority areas for global conservation. 
Bishop, J., \& Landell-Mills, N. (2002). Forest environmental services: an overview. 2002). Selling forest environmental services-Market-based mechanisms for conservation and development, 15-36.

Brooks, T. (2010). Conservation planning and priorities. Conservation Biology for All. Oxford University Press, Oxford, 199-219.

Brooks, T. M., Mittermeier, R. A., da Fonseca, G. A., Gerlach, J., Hoffmann, M., Lamoreux, J. F., ... \& Rodrigues, A. S. (2006). Global biodiversity conservation priorities. science, 313(5783), 58-61.

Brooks, T. M., Mittermeier, R. A., Mittermeier, C. G., Da Fonseca, G. A., Rylands, A. B., Konstant, W. R., ... \& Hilton-Taylor, C. (2002). Habitat loss and extinction in the hotspots of biodiversity. Conservation biology, 16(4), 909-923.

Brown, K. A., \& Gurevitch, J. (2004). Long-term impacts of logging on forest diversity in Madagascar. Proceedings of the National Academy of Sciences of the United States of America, 101(16), 6045-6049.

Bruner, A. G., Gullison, R. E., Rice, R. E., \& Da Fonseca, G. A. (2001). Effectiveness of parks in protecting tropical biodiversity. Science, 291(5501), 125-128.

Cardillo, M., Purvis, A., Sechrest, W., Gittleman, J. L., Bielby, J., \& Mace, G. M. (2004). Human population density and extinction risk in the world's carnivores. PLoS Biol, 2(7), e197.

Caro, T. M., \& O'Doherty, G. (1999). On the use of surrogate species in conservation biology. Conservation biology, 805-814.

Change, I. P. O. C. (2007). Climate change 2007: The physical science basis. Agenda, 6(07), 333.

Chazdon, R. L., Peres, C. A., Dent, D., Sheil, D., Lugo, A. E., Lamb, D., ... \& Miller, S. E. (2009). The potential for species conservation in tropical secondary forests. Conservation Biology, 23(6), 1406-1417. 
Cincotta, R. P., Wisnewski, J., \& Engelman, R. (2000). Human population in the biodiversity hotspots. Nature, 404(6781), 990-992.

Costello, C., \& Polasky, S. (2004). Dynamic reserve site selection. Resource and Energy Economics, 26(2), 157-174.

Cowling, R. M., \& Pressey, R. L. (2003). Introduction to systematic conservation planning in the Cape Floristic Region. Biological Conservation, 112(1), 1-13.

Cuesta-Camacho, F., Peralvo, M., Ganzenmüller, A., Sáenz, M., Novoa, J., Riofrío, G., Beltrán, K. (2006). Identificación de vacíos y prioridades de conservación para la biodiversidad terrestre en el Ecuador Continental. Ecociencia, Quito-Ecuador.

Dalerum, F. (2014). Identifying the role of conservation biology for solving the environmental crisis. Ambio, 43(7), 839-846.

Davis, S.D., V.H. Heywood, O. Herrera-MacBryde, J. Villa-Lobos, \& A. Hamilton (Eds.). 1997. Centres of Plant Diversity: A Guide and Strategy for Their Conservation. Volume 3: The Americas. IUCN Publications Unit, Cambridge, England.

De Oliveira, J. A. P. (2002). Implementing environmental policies in developing countries through decentralization: the case of protected areas in Bahia, Brazil. World Development, 30(10), 1713-1736.

DeFries, R. S., Rudel, T., Uriarte, M., \& Hansen, M. (2010). Deforestation driven by urban population growth and agricultural trade in the twenty-first century. Nature Geoscience, 3(3), 178-181.

DeFries, R., Achard, F., Brown, S., Herold, M., Murdiyarso, D., Schlamadinger, B., \& de Souza, C. (2007). Earth observations for estimating greenhouse gas emissions from deforestation in developing countries. environmental science \& policy, 10(4), 385-394.

DeFries, R., Hansen, A., Newton, A. C., \& Hansen, M. C. (2005). Increasing isolation of protected areas in tropical forests over the past twenty years. Ecological Applications, 15(1), 19-26. 
DeFries, R., Hansen, A., Turner, B. L., Reid, R., \& Liu, J. (2007). Land use change around protected areas: management to balance human needs and ecological function. Ecological Applications, 17(4), 1031-1038.

Dickinson, R. E., \& Kennedy, P. (1992). Impacts on regional climate of Amazon deforestation. Geophysical Research Letters, 19(19), 1947-1950.

Dodson, C. H., \& Gentry, A. H. (1991). Biological extinction in western Ecuador. Annals of the Missouri Botanical Garden, 273-295.

Downer, C. C. (1996). The mountain tapir, endangered 'flagship'species of the high Andes. Oryx, 30(01), 45-58.

Ehrlich, P. R., \& Holdren, J. P. (1971). Impact of population growth.

Elbers, J. (2011). Las areas protegidas de America Latina: Solucion actual y perspectivas para el futuro, IUCN and Ministerio de Medio Ambiente y Medio Rural y Marino de Espana, 230 pp.

Ellis, E. A., \& Porter-Bolland, L. (2008). Is community-based forest management more effective than protected areas?: A comparison of land use/land cover change in two neighboring study areas of the Central Yucatan Peninsula, Mexico. Forest ecology and management, 256(11), 1971-1983.

Ellis, E. C., \& Ramankutty, N. (2008). Putting people in the map: anthropogenic biomes of the world. Frontiers in Ecology and the Environment, 6(8), 439-447.

Ernst, R., Linsenmair, K. E., \& Rödel, M. O. (2006). Diversity erosion beyond the species level: dramatic loss of functional diversity after selective logging in two tropical amphibian communities. Biological Conservation, 133(2), 143-155.

Espinosa, C. I., De la Cruz, M., Luzuriaga, A. L., \& Escudero, A. (2012). Bosques tropicales secos de la región Pacífico Ecuatorial: diversidad, estructura, funcionamiento e implicaciones para la conservación. Revista Ecosistemas, 21(1-2). 
Ewers, R. M., \& Didham, R. K. (2006). Confounding factors in the detection of species responses to habitat fragmentation. Biological Reviews, 81(01), 117-142.

Fahrig, L. (2003). Effects of habitat fragmentation on biodiversity. Annual review of ecology, evolution, and systematics, 487-515.

Favreau, J. M., Drew, C. A., Hess, G. R., Rubino, M. J., Koch, F. H., \& Eschelbach, K. A. (2006). Recommendations for assessing the effectiveness of surrogate species approaches. Biodiversity \& Conservation, 15(12), 3949-3969.

Ferraz, G., Russell, G. J., Stouffer, P. C., Bierregaard, R. O., Pimm, S. L., \& Lovejoy, T. E. (2003). Rates of species loss from Amazonian forest fragments. Proceedings of the National Academy of Sciences, 100(24), 14069-14073.

Fishpool, L. D., \& Evans, M. I. (Eds.). (2001). Important Bird Areas in Africa and associated islands: Priority sites for conservation. Cambridge, UK: BirdLife International.

Foley, J. A., DeFries, R., Asner, G. P., Barford, C., Bonan, G., Carpenter, S. R., ... \& Snyder, P. K. (2005). Global consequences of land use. science, 309(5734), 570-574.

Gallo, J. A., Pasquini, L., Reyers, B., \& Cowling, R. M. (2009). The role of private conservation areas in biodiversity representation and target achievement within the Little Karoo region, South Africa. Biological Conservation, 142(2), 446-454.

Game, E. T., McDONAld-MADDEN, E. V. E., Puotinen, M. L., \& Possingham, H. P. (2008). Should we protect the strong or the weak? Risk, resilience, and the selection of marine protected areas. Conservation Biology, 22(6), 1619-1629.

Gärdenfors, U., Hilton-Taylor, C., Mace, G. M., \& Rodríguez, J. P. (2001). The application of IUCN Red List criteria at regional levels. Conservation Biology, 15(5), 1206-1212.

Gaston, K. J. (1998). Species-range size distributions: products of speciation, extinction and transformation. Philosophical Transactions of the Royal Society B: Biological Sciences, 353(1366), 219-230. 
Geist, H. J., \& Lambin, E. F. (2002). Proximate Causes and Underlying Driving Forces of Tropical Deforestation Tropical forests are disappearing as the result of many pressures, both local and regional, acting in various combinations in different geographical locations. BioScience, 52(2), 143-150.

Gentry, A. H. (1977). Endangered plant species and habitats of Ecuador and Amazonian Peru. Extinction is forever, 136-149.

Gerber, L. \& González-Suárez, M. (2010). Population Viability Analysis: Origins and Contributions. Nature Education Knowledge 3(10):15

Gibson, L., Lee, T. M., Koh, L. P., Brook, B. W., Gardner, T. A., Barlow, J., ... \& Sodhi, N. S. (2011). Primary forests are irreplaceable for sustaining tropical biodiversity. Nature, 478(7369), 378-381.

Groves, C. (2003). Drafting a conservation blueprint: a practitioner's guide to planning for biodiversity. Island Press.

Groves, C. R., Jensen, D. B., Valutis, L. L., Redford, K. H., Shaffer, M. L., Scott, J. M., \& Anderson, M. G. (2002). Planning for Biodiversity Conservation: Putting Conservation Science into Practice A seven-step framework for developing regional plans to conserve biological diversity, based upon principles of conservation biology and ecology, is being used extensively by the nature conservancy to identify priority areas for conservation. BioScience, 52(6), 499-512.

Hansen, A. J., \& DeFries, R. (2007). Ecological mechanisms linking protected areas to surrounding lands. Ecological Applications, 17(4), 974-988.

Hansen, M. C., Potapov, P. V., Moore, R., Hancher, M., Turubanova, S. A., Tyukavina, A., ... \& Townshend, J. R. G. (2013). High-resolution global maps of 21st-century forest cover change. science, 342(6160), 850-853.

Henderson-Sellers, A., Dickinson, R. E., Durbidge, T. B., Kennedy, P. J., McGuffie, K., \& Pitman, A. J. (1993). Tropical deforestation: Modeling local-to regional-scale climate 
change. Journal of Geophysical Research: Atmospheres (1984-2012), 98(D4), 72897315 .

Hill, J. K., Gray, M. A., Khen, C. V., Benedick, S., Tawatao, N., \& Hamer, K. C. (2011). Ecological impacts of tropical forest fragmentation: how consistent are patterns in species richness and nestedness?. Philosophical Transactions of the Royal Society B: Biological Sciences, 366(1582), 3265-3276.

Hosonuma, N., Herold, M., De Sy, V., De Fries, R. S., Brockhaus, M., Verchot, L., ... \& Romijn, E. (2012). An assessment of deforestation and forest degradation drivers in developing countries. Environmental Research Letters, 7(4), 044009.

Hutton, J., Adams, W. M., \& Murombedzi, J. C. (2005, December). Back to the barriers? Changing narratives in biodiversity conservation. In Forum for development studies (Vol. 32, No. 2, pp. 341-370). Taylor \& Francis Group.

Iñiguez, C. A., \& Morejón, F. J. (2012). Potential distribution of the american bullfrog (Lithobates catesbeianus) in ecuador. south american Journal of herpetology, 7(2), 8590.

Johns, A. D. (1988). Effects of" selective" timber extraction on rain forest structure and composition and some consequences for frugivores and folivores. Biotropica, 31-37.

Jørgensen, P. M., \& León-Yánez, S. (1999). Catálogo de las plantas vasculares del Ecuador. Monographs in Systematic Botany from the Missouri Botanical Garden, 75, $1-1181$.

Kareiva, P., \& Marvier, M. (2012). What is conservation science?. BioScience, 62(11), 962-969.

Kiester, A. R., Scott, J. M., Csuti, B., Noss, R. F., Butterfield, B., Sahr, K., \& White, D. (1996). Conservation prioritization using GAP data. Conservation Biology, 10(5), 1332-1342. 
Kiester, A. R., Scott, J. M., Csuti, B., Noss, R. F., Butterfield, B., Sahr, K., \& White, D. (1996). Conservation prioritization using GAP data. Conservation Biology, 10(5), $1332-1342$.

Knight, A. T., Cowling, R. M., \& Campbell, B. M. (2006). An operational model for implementing conservation action. Conservation Biology, 20(2), 408-419.

Kouki, J., Löfman, S., Martikainen, P., Rouvinen, S., \& Uotila, A. (2001). Forest fragmentation in Fennoscandia: linking habitat requirements of wood-associated threatened species to landscape and habitat changes. Scandinavian Journal of Forest Research, 16(S3), 27-37.

Kremen, C., Cameron, A., Moilanen, A., Phillips, S. J., Thomas, C. D., Beentje, H., ... \& Zjhra, M. L. (2008). Aligning conservation priorities across taxa in Madagascar with high-resolution planning tools. Science, 320(5873), 222-226.

Lamoreux, J. F., Morrison, J. C., Ricketts, T. H., Olson, D. M., Dinerstein, E., McKnight, M. W., \& Shugart, H. H. (2006). Global tests of biodiversity concordance and the importance of endemism. Nature, 440(7081), 212-214.

Laumonier, Y., Uryu, Y., Stüwe, M., Budiman, A., Setiabudi, B., \& Hadian, O. (2010). Eco-floristic sectors and deforestation threats in Sumatra: identifying new conservation area network priorities for ecosystem-based land use planning. Biodiversity and Conservation, 19(4), 1153-1174.

Laurance, W. F. (1999). Reflections on the tropical deforestation crisis. Biological Conservation, 91(2), 109-117.

Laurance, W. F., \& Bierregaard, R. O. (1997). Tropical forest remnants: ecology, management, and conservation of fragmented communities. University of Chicago Press.

Laurance, W. F., Camargo, J. L., Luizão, R. C., Laurance, S. G., Pimm, S. L., Bruna, E. M., ... \& Lovejoy, T. E. (2011). The fate of Amazonian forest fragments: a 32-year investigation. Biological Conservation, 144(1), 56-67. 
Laurance, W. F., Lovejoy, T. E., Vasconcelos, H. L., Bruna, E. M., Didham, R. K., Stouffer, P. C., ... \& Sampaio, E. (2002). Ecosystem decay of Amazonian forest fragments: a 22-year investigation. Conservation Biology, 16(3), 605-618.

Laurance, W. F., Useche, D. C., Rendeiro, J., Kalka, M., Bradshaw, C. J., Sloan, S. P., ... \& Plumptre, A. (2012). Averting biodiversity collapse in tropical forest protected areas. Nature, 489(7415), 290-294.

León-Yánez, S., R. Valencia, N. Pitman, L. Endara, C. Ulloa Ulloa \& H. Navarrete (eds.). 2011. Libro rojo de las plantas endémicas del Ecuador, $2^{a}$ edición. Publicaciones del Herbario QCA, Pontificia Universidad Católica del Ecuador, Quito.

Lessmann, J., Munoz, J., \& Bonaccorso, E. (2014). Maximizing species conservation in continental Ecuador: a case of systematic conservation planning for biodiverse regions. Ecology and evolution, 4(12), 2410-2422.

Linares-Palomino, R., Oliveira-Filho, A. T., \& Pennington, R. T. (2011). Neotropical seasonally dry forests: diversity, endemism, and biogeography of woody plants. In Seasonally Dry Tropical Forests (pp. 3-21). Island Press/Center for Resource Economics.

Lotze, H. K., Lenihan, H. S., Bourque, B. J., Bradbury, R. H., Cooke, R. G., Kay, M. C., ... \& Jackson, J. B. (2006). Depletion, degradation, and recovery potential of estuaries and coastal seas. Science, 312(5781), 1806-1809.

Loyola, R. D., Kubota, U., \& Lewinsohn, T. M. (2007). Endemic vertebrates are the most effective surrogates for identifying conservation priorities among Brazilian ecoregions. Diversity and Distributions, 13(4), 389-396.

Lozano, P. (2002). Los tipos de bosque en el sur de Ecuador. Bótanica Austroecuatoriana. Estudios sobre los recursos vegetales en las provincial de El Oro, Loja y ZamoraChinchipe. Abya-Yala, Quito, 29-49.

Margules, C. R., \& Pressey, R. L. (2000). Systematic conservation planning. Nature, 405(6783), 243-253. 
Margules, C. R., Pressey, R. L., \& Williams, P. H. (2002). Representing biodiversity: data and procedures for identifying priority areas for conservation. Journal of biosciences, 27(4), 309-326.

Mascia, M. B., Brosius, J. P., Dobson, T. A., Forbes, B. C., Horowitz, L., McKean, M. A., \& Turner, N. J. (2003). Conservation and the social sciences. Conservation Biology, 17(3), 649-650.

Mateo, R. G., de la Estrella, M., Felicísimo, Á. M., Muñoz, J., \& Guisan, A. (2013). A new spin on a compositionalist predictive modelling framework for conservation planning: a tropical case study in Ecuador. Biological conservation, 160, 150-161.

Meine, C., Soule, M., \& Noss, R. F. (2006). “A Mission-Driven Discipline”: the Growth of Conservation Biology. Conservation biology, 20(3), 631-651.

Meir, E., Andelman, S., \& Possingham, H. P. (2004). Does conservation planning matter in a dynamic and uncertain world?. Ecology Letters, 7(8), 615-622.

Menéndez-Guerrero, P. A., \& Graham, C. H. (2013). Evaluating multiple causes of amphibian declines of Ecuador using geographical quantitative analyses. Ecography, 36(7), 756-769.

Messina, J. P., Walsh, S. J., Mena, C. F., \& Delamater, P. L. (2006). Land tenure and deforestation patterns in the Ecuadorian Amazon: Conflicts in land conservation in frontier settings. Applied Geography, 26(2), 113-128.

Meyer, W. B., \& Turner, B. L. (1992). Human population growth and global land-use/cover change. Annual review of ecology and systematics, 39-61.

Moore, J. L., Balmford, A., Brooks, T., Burgess, N. D., Hansen, L. A., Rahbek, C., \& Williams, P. H. (2003). Performance of Sub-Saharan Vertebrates as Indicator Groups for Identifying Priority Areas for Conservation. Conservation Biology, 17(1), 207-218. 
Mosandl, R., Günter, S., Stimm, B., \& Weber, M. (2008). Ecuador suffers the highest deforestation rate in South America. In Gradients in a tropical mountain ecosystem of Ecuador (pp. 37-40). Springer Berlin Heidelberg.

Myers, N. (1988). Threatened biotas:" hot spots" in tropical forests. Environmentalist, 8(3), 187-208.

Myers, N. (1993). Tropical forests: the main deforestation fronts. Environmental Conservation, 20(01), 9-16.

Myers, N., Mittermeier, R. A., Mittermeier, C. G., Da Fonseca, G. A., \& Kent, J. (2000). Biodiversity hotspots for conservation priorities. Nature, 403(6772), 853-858.

Myers, N., Mittermeier, R. A., Mittermeier, C. G., Da Fonseca, G. A., \& Kent, J. (2000). Biodiversity hotspots for conservation priorities. Nature, 403(6772), 853-858.

Naidoo, R., Balmford, A., Ferraro, P. J., Polasky, S., Ricketts, T. H., \& Rouget, M. (2006). Integrating economic costs into conservation planning. Trends in ecology \& evolution, 21(12), 681-687.

Neill, D. 2000. Observations on the conservation status of Tropical Dry Forest in the Zapotillo Area, Loja. ww.mobot.org/MOBOT/research/Ecuador/Zapotillo

Nelson, A., \& Chomitz, K. M. (2011). Effectiveness of strict vs. multiple use protected areas in reducing tropical forest fires: a global analysis using matching methods. PLoS One, 6(8), e22722.

Nepstad, D., Schwartzman, S., Bamberger, B., Santilli, M., Ray, D., Schlesinger, P., ... \& Rolla, A. (2006). Inhibition of Amazon deforestation and fire by parks and indigenous lands. Conservation Biology, 20(1), 65-73.

Nobre, C. A., Sellers, P. J., \& Shukla, J. (1991). Amazonian deforestation and regional climate change. Journal of Climate, 4(10), 957-988.

Norman, M. (1984). The primary source: tropical forests and our future. 
Olson, D. M., \& Dinerstein, E. (1998). The Global 200: a representation approach to conserving the Earth's most biologically valuable ecoregions. Conservation Biology, 12(3), 502-515.

Olson, D. M., \& Dinerstein, E. (1998). The Global 200: a representation approach to conserving the Earth's most biologically valuable ecoregions. Conservation Biology, 12(3), 502-515.

Orme, C. D. L., Davies, R. G., Burgess, M., Eigenbrod, F., Pickup, N., Olson, V. A., ... \& Owens, I. P. (2005). Global hotspots of species richness are not congruent with endemism or threat. Nature, 436(7053), 1016-1019.

Pärtel, M., Kalamees, R., Reier, Ü., Tuvi, E. L., Roosaluste, E., Vellak, A., \& Zobel, M. (2005). Grouping and prioritization of vascular plant species for conservation: combining natural rarity and management need. Biological Conservation, 123(3), 271278.

Pasquini, L., Fitzsimons, J. A., Cowell, S., Brandon, K., \& Wescott, G. (2011). The establishment of large private nature reserves by conservation NGOs: key factors for successful implementation. Oryx, 45(03), 373-380.

Pearson, D. L., \& Carroll, S. S. (1998). Global patterns of species richness: spatial models for conservation planning using bioindicator and precipitation data. Conservation biology, 12(4), 809-821.

Peres, C. A. (1994). Indigenous reserves and nature conservation in Amazonian forests. Conservation Biology, 586-588.

Persha, L., Agrawal, A., \& Chhatre, A. (2011). Social and ecological synergy: local rulemaking, forest livelihoods, and biodiversity conservation. science, 331(6024), 1606-1608.

Pichón, F. J. (1997). Colonist land-allocation decisions, land use, and deforestation in the Ecuadorian Amazon frontier. Economic Development and Cultural Change, 45(4), 707-744. 
Pimbert, M., \& Pretty, J. N. (1995). Parks, people and professionals. Geneva: United Nations ResearchInstitute for Social Development.

Possingham, H. P., Andelman, S. J., Burgman, M. A., Medellín, R. A., Master, L. L., \& Keith, D. A. (2002). Limits to the use of threatened species lists. Trends in ecology \& evolution, 17(11), 503-507.

Pressey, R. L., \& Taffs, K. H. (2001). Scheduling conservation action in production landscapes: priority areas in western New South Wales defined by irreplaceability and vulnerability to vegetation loss. Biological Conservation, 100(3), 355-376.

Pressey, R. L., Humphries, C. J., Margules, C. R., Vane-Wright, R. I., \& Williams, P. H. (1993). Beyond opportunism: key principles for systematic reserve selection. Trends in ecology \& evolution, 8(4), 124-128.

Pressey, R. L., Johnson, I. R., \& Wilson, P. D. (1994). Shades of irreplaceability: towards a measure of the contribution of sites to a reservation goal. Biodiversity \& Conservation, 3(3), 242-262.

Pressey, R. L., Possingham, H. P., \& Margules, C. R. (1996). Optimality in reserve selection algorithms: when does it matter and how much?. Biological Conservation, 76(3), 259-267.

Pressey, R. L., Watts, M. E., \& Barrett, T. W. (2004). Is maximizing protection the same as minimizing loss? Efficiency and retention as alternative measures of the effectiveness of proposed reserves. Ecology Letters, 7(11), 1035-1046.

Redding, D. W., \& Mooers, A. Ø. (2006). Incorporating evolutionary measures into conservation prioritization. Conservation Biology, 20(6), 1670-1678.

Redford, K. H., \& Stearman, A. M. (1993). Forest-Dwelling Native Amazonians and the Conservation of Biodiversity: Interests in Common or in Collision?. Conservation Biology, 7(2), 248-255. 
Redford, K. H., Coppolillo, P., Sanderson, E. W., Da Fonseca, G. A., Dinerstein, E., Groves, C., ... \& Wright, M. (2003). Mapping the conservation landscape. Conservation biology, 17(1), 116-131.

Richter, M., Diertl, K. H., Emck, P., Peters, T., \& Beck, E. (2009). Reasons for an outstanding plant diversity in the tropical Andes of Southern Ecuador. Landscape Online, 12(2009), 1-35.

Rodrigues, A. S., \& Brooks, T. M. (2007). Shortcuts for biodiversity conservation planning: the effectiveness of surrogates. Annual Review of Ecology, Evolution, and Systematics, 713-737.

Rodrigues, A. S., Andelman, S. J., Bakarr, M. I., Boitani, L., Brooks, T. M., Cowling, R. M., ... \& Yan, X. (2004). Effectiveness of the global protected area network in representing species diversity. Nature, 428(6983), 640-643.

Rodríguez, L. O., \& Young, K. R. (2000). Biological diversity of Peru: determining priority areas for conservation. AMBIO: A Journal of the Human Environment, 29(6), 329337.

Rudel, T. A., \& Horowitz, B. (2013). Tropical Deforestation: Small Farmers and Land Clearing in Ecuadorian Amazon. Columbia University Press.

Sánchez-Azofeifa, G. A., Quesada-Mateo, C., Gonzalez-Quesada, P., Dayanandan, S., \& Bawa, K. S. (1999). Protected areas and conservation of biodiversity in the tropics. Conservation Biology, 13(2), 407-411.

Sanderson, E. W., Jaiteh, M., Levy, M. A., Redford, K. H., Wannebo, A. V., \& Woolmer, G. (2002). The Human Footprint and the Last of the Wild: the human footprint is a global map of human influence on the land surface, which suggests that human beings are stewards of nature, whether we like it or not. BioScience, 52(10), 891-904.

Sarkar, S., \& Illoldi-Rangel, P. (2010). Systematic conservation planning: an updated protocol. Natureza \& Conservação, 8(1), 19-26. 
Sarkar, S., Pressey, R. L., Faith, D. P., Margules, C. R., Fuller, T., Stoms, D. M., ... \& Andelman, S. (2006). Biodiversity conservation planning tools: present status and challenges for the future. Annu. Rev. Environ. Resour., 31, 123-159.

Schwartzman, S., Moreira, A., \& Nepstad, D. (2000). Rethinking tropical forest conservation: perils in parks. Conservation Biology, 14(5), 1351-1357.

Shukla, J., Nobre, C., \& Sellers, P. (1990). Amazon deforestation and climate change. Science(Washington), 247(4948), 1322-1325.

Sierra, M. (1999). Propuesta preliminar de un sistema de clasificación de vegetación para el Ecuador continental. Proyecto Inefan/Gef-Birf y Ecociencia.

Sierra, M., Campos, F., \& Chamberlin, J. (1999). Areas Prioritarias para la Conservación de la Biodiversidad en el Ecuador Continental. Ministerio de Medio Ambiente; Proyecto INEFAN/GEF-BIRF; EcoCiencia; Wildlife Conservation Society.

Sierra, R. (2000). Dynamics and patterns of deforestation in the western Amazon: the Napo deforestation front, 1986-1996. Applied geography, 20(1), 1-16.

Sierra, R., \& Stallings, J. (1998). The dynamics and social organization of tropical deforestation in Northwest Ecuador, 1983-1995. Human Ecology, 26(1), 135-161.

Sierra, R., Campos, F., \& Chamberlin, J. (2002). Assessing biodiversity conservation priorities: ecosystem risk and representativeness in continental Ecuador. Landscape and Urban Planning, 59(2), 95-110.

Simberloff, D. (1998). Flagships, umbrellas, and keystones: is single-species management passé in the landscape era?. Biological conservation, 83(3), 247-257.

Skole, D., \& Tucker, C. (1993). Tropical deforestation and habitat fragmentation in the Amazon. Satellite data from 1978 to 1988. Science(Washington), 260(5116), 19051910. 
Skole, D., \& Tucker, C. (1993). Tropical deforestation and habitat fragmentation in the Amazon. Satellite data from 1978 to 1988. Science(Washington), 260(5116), 19051910.

Snyder, P. K., Delire, C., \& Foley, J. A. (2004). Evaluating the influence of different vegetation biomes on the global climate. Climate Dynamics, 23(3-4), 279-302.

Soulé, M. E. (1985). What is conservation biology? A new synthetic discipline addresses the dynamics and problems of perturbed species, communities, and ecosystems. BioScience, 35(11), 727-734.

Stattersfield, A. J., Crosby, M. J., Long, A. J., \& Wege, D. C. (1998). Global directory of endemic bird areas. BirdLife International, Cambridge, United Kingdom.

Steffen, W., Sanderson, R. A., Tyson, P. D., Jäger, J., Matson, P. A., Moore III, B., ... \& Wasson, R. J. (2006). Global change and the earth system: a planet under pressure. Springer Science \& Business Media.

Strange, N., Thorsen, B. J., \& Bladt, J. (2006). Optimal reserve selection in a dynamic world. Biological Conservation, 131(1), 33-41.

Sud, Y. C., Yang, R., \& Walker, G. K. (1996). Impact of in situ deforestation in Amazonia on the regional climate: General circulation model simulation study. Journal of Geophysical Research: Atmospheres (1984-2012), 101(D3), 7095-7109.

Tapia-Armijos, M. F., Homeier, J., Espinosa, C. I., Leuschner, C., \& de la Cruz, M. (2015). Deforestation and Forest Fragmentation in South Ecuador since the 1970s-Losing a Hotspot of Biodiversity. PloS one, 10(9), e0133701.

Terborgh, J., Estes, J. A., Paquet, P., Ralls, K., Boyd-Herger, D., Miller, B. J., \& Noss, R. F. (1999). The role of top carnivores in regulating terrestrial ecosystems.

Thiollay, J. (1992). Influence of selective logging on bird species diversity in a Guianan rain forest. Conservation biology, 6(1), 47-63. 
Thuiller, W., Richardson, D. M., Rouget, M., Proches, S., \& Wilson, J. R. (2006). Interactions between environment, species traits, and human uses describe patterns of plant invasions. Ecology, 87(7), 1755-1769.

Tinoco, B. A. (2009). Seasonality of the bird community in the Tumbesian dry forest in south west Ecuador. ORNITOLOGIA NEOTROPICAL, 20(2), 157-170.

Turner, I. M., \& Corlett, R. T. (1996). The conservation value of small, isolated fragments of lowland tropical rain forest. Trends in Ecology \& Evolution, 11(8), 330-333.

United Nations, Department of Economic and Social Affairs, Population Division (2015). World Population Prospects: The 2015 Revision, Key Findings and Advance Tables. Working Paper No. ESA/P/WP.241.

Visconti, P., \& Joppa, L. (2015). Building robust conservation plans. Conservation Biology, 29(2), 503-512.

Vitousek, P. M. (1994). Beyond global warming: ecology and global change. Ecology, 75(7), 1861-1876.

Vitousek, P. M., Mooney, H. A., Lubchenco, J., \& Melillo, J. M. (1997). Human domination of Earth's ecosystems. Science, 277(5325), 494-499.

Walker, B., \& Steffen, W. (1997). An overview of the implications of global change for natural and managed terrestrial ecosystems. Conservation Ecology,1(2), 2.

Walther, G. R., Post, E., Convey, P., Menzel, A., Parmesan, C., Beebee, T. J., ... \& Bairlein, F. (2002). Ecological responses to recent climate change.Nature, 416(6879), 389-395.

Watson, J. E., Grantham, H., Wilson, K. A., \& Possingham, H. P. (2011). Systematic conservation planning: Past, present and future. Wiley-Blackwell, 136-160.

Weigend, M. (2002). Observations on the biogeography of the Amotape-Huancabamba zone in northern Peru. The Botanical Review, 68(1), 38-54. 
Weigend, M. (2004). Additional observations on the biogeography of the AmotapeHuancabamba zone in Northern Peru: Defining the South-Eastern limits. Rev. peru. biol, 11(2), 127-134.

Weigend, M., Rodríguez, E. F., \& Arana, C. (2005). The relict forests of northwest Peru and southwest Ecuador. Revista Peruana de Biología, 12(2), 185-194.

West, P., Igoe, J., \& Brockington, D. (2006). Parks and peoples: the social impact of protected areas. Annu. Rev. Anthropol., 35, 251-277.

Whittaker, R. J., Araújo, M. B., Jepson, P., Ladle, R. J., Watson, J. E., \& Willis, K. J. (2005). Conservation biogeography: assessment and prospect. Diversity and distributions, 11(1), 3-23.

Wilkie, D. S., Sidle, J. G., \& Boundzanga, G. C. (1992). Mechanized logging, market hunting, and a bank loan in Congo. Conservation Biology, 570-580.

Wilson, E. O. (1988). The current state of biological diversity. Biodiversity, 521(1), 3-18.

Wilson, K. A., Cabeza, M., \& Klein, C. J. (2009). Fundamental concepts of spatial conservation prioritization. Spatial Conservation Prioritization: Quantitative Methods and Computational Tools. Oxford University Press, New York, 16-27.

Wilson, K. A., Underwood, E. C., Morrison, S. A., Klausmeyer, K. R., Murdoch, W. W., Reyers, B., ... \& Possingham, H. P. (2007). Conserving biodiversity efficiently: what to do, where, and when. PLoS Biol, 5(9), e223.

Woodroffe, R. (2000). Predators and people: using human densities to interpret declines of large carnivores. Animal conservation, 3(02), 165-173.

Wright, S. J. (2005). Tropical forests in a changing environment. Trends in Ecology \& Evolution, 20(10), 553-560.

Wuebbles, D. J., \& Jain, A. K. (2001). Concerns about climate change and the role of fossil fuel use. Fuel processing technology, 71(1), 99-119. 
Wunder, S. (2000). The economics of deforestation: the example of Ecuador.

Young, K. R., \& Reynel, C. (1997). Huancabamba region, Peru and ecuador. Centers of Plant Diversity, a guide and strategy for their conservation, 3, 465-469.

Zapata-Ríos, G., Urgiles, C., \& Suárez, E. (2009). Mammal hunting by the Shuar of the Ecuadorian Amazon: is it sustainable?. Oryx, 43(03), 375-385. 


\section{CHAPTER 2}

\section{Deforestation and Forest Fragmentation in}

\section{South Ecuador since the 1970s - Losing a Hotspot of Biodiversity}

María Fernanda Tapia-Armijos ${ }^{1,2}$, Jürgen Homeier ${ }^{2}$, Carlos Iván Espinosa $^{1}$, Christoph Leuschner ${ }^{2}$, Marcelino de la $\mathrm{Cruz}^{3}$

${ }^{1}$ Sección de Ecología y Sistemática, Departamento de Ciencias Naturales, Universidad Técnica Particular de Loja, Loja, Ecuador,

${ }^{2}$ Plant Ecology, Albrecht von Haller Institute for Plant Sciences, University of Göttingen, Göttingen, Germany,

3 Área de Biodiversidad y Conservación, Departamento de Biología y Geología, ESCET, Universidad Rey Juan Carlos, Madrid, Spain

PLOS ONE 10(9): e0133701 


\section{Deforestation and forest fragmentation in South Ecuador since the 1970s - losing a hotspot of biodiversity}

\subsection{Abstract}

Deforestation and fragmentation are major components of global change; both are contributing to the rapid loss of tropical forest area with important implications for ecosystem functioning and biodiversity conservation. The forests of South Ecuador are a biological 'hotspot' due to their high diversity and endemism levels. We examined the deforestation and fragmentation patterns in this area of high conservation value using aerial photographs and Aster satellite scenes. The registered annual deforestation rates of $0.75 \%$ (1976 - 1989) and 2.86\% (1989 - 2008) for two consecutive survey periods, the decreasing mean patch size and the increasing isolation of the forest fragments show that the area is under severe threat. Approximately $46 \%$ of South Ecuador's original forest cover had been converted by 2008 into pastures and other anthropogenic land cover types. We found that deforestation is more intense at lower elevations (premontane evergreen forest and shrubland) and that the deforestation front currently moves in upslope direction. Improved awareness of the spatial extent, dynamics and patterns of deforestation and forest fragmentation is urgently needed in biologically diverse areas like South Ecuador.

\subsection{Introduction}

Deforestation and forest fragmentation are among the main components of global change (Vitousek, 1994) and both contribute to the rapid loss of tropical forest area with important implications for ecosystem functioning and biodiversity conservation (Young et al., 1996; Young and Clarke, 2000). Deforestation has been directly linked to species extinctions (Brook et al., 2003), loss of ecosystem services (Homeier et al., 2013), enhanced emission of CO2 and other greenhouse gases (Fearnside and Laurancem, 2004; Eva et al., 2012), and changes in the structure and habitat quality of aquatic ecosystems (Iñiguez-Armijos et al., 2014). 
Deforestation not only reduces forest area but also changes the landscape configuration (Skole and Tucker, 1998). Fragmentation increases habitat isolation and edge effects and reduces the size of forest patches (Fahrig, 2003). The resulting smaller patches exist under different abiotic conditions and meta-population environments than the un-fragmented forest (Saunders et al., 1991), thereby limiting the available resources needed to maintain local populations, presenting barriers that some species are unable to cross, and influencing species interactions (Fahrig, 2003; Fischer and Lindermayer, 2007).

According to the Food and Agriculture Organization of the United Nations (FAO, 2011), Ecuador has maintained the highest deforestation rates in South America during the last 20 years (annual rates of 1.5\% and 1.8\% for the 1990-2000 and 2001-2010 periods, respectively). As in other tropical countries, agricultural expansion, wood extraction for fuel, commercial logging, the establishment of oil palm, cacao and banana plantations, bioethanol cropping, mining and road construction are main drivers of ongoing land cover changes (Lambin et al., 2003; Laurence et al., 2009; Macedo et al., 2012).

In Ecuador, the highest deforestation rates reported to date have been detected in the northwestern Amazon and the northwestern coastal regions (e.g. Sierra and Stallings, 1998; Sierra, 1999; Rudel et al., 2002; Viña et al., 2004; Mena, 2008). With the exception of the studies of Keating (1998)] and Thies et al. (2012), there is only scarce information on deforestation rates in South Ecuador, which is thought to be an important front of deforestation in the country. At the same time, this region is of particular interest and value for biodiversity conservation (Sierra et al., 2002).

South Ecuador (the provinces of Loja and Zamora Chinchipe) has been identified as a center of biodiversity (e.g. Brehm et al., 2008; Brehm et al., 2005) and a large part is situated within the Tropical Andes biodiversity hotspot, which is considered as the richest hotspot on earth (Brummit and Nic Lughadha, 2003; Bartlott et al., 2005). Furthermore, the south-western part of Loja province is part of the Tumbes - Chocó - Magdalena biodiversity hotspot which includes the unique dry forests of Ecuador and Peru (RodriguezMahecha et al., 2004). 
South Ecuador is characterized by a very specific flora which differs markedly from the rest of the country and has a high degree of endemism [Weigend, 2002; Weigend, 2004). According to Valencia et al. (2000), from the 4,011 endemic species of Ecuador, 639 are registered for Loja, and 568 for Zamora Chinchipe and of these 515 are exclusive for the region. Podocarpus National Park, the most important protected forest area in the region, has the highest number of endemic vascular plants species (211) of all other protected areas in the country (Valencia et al., 2000). Its high biodiversity and endemism were the reason to include a great share of the region in the recently created Podocarpus - El Cóndor Biosphere Reserve (MAE, 2010).

Recent studies focusing on small areas in this region reported high rates of deforestation (Thies et al., 2012; Torracchi et al., 2012).Drastic effects of deforestation and fragmentation on species richness and composition have been documented (e.g. Homeier et al., 2013; Brehm et al., 2005; Werner et al., 2005; Nöske et al., 2008). Against this background, this study aimed at describing land cover change and changes in forest spatial configuration in the highly diverse South Ecuadorian forest region since the 1970`s by 1) determining deforestation rates in the region during the periods 1976 - 1989 and 1989 $2008,2)$ identifying which are the natural forest types that have suffered the highest conversion rates and 3) evaluating the changes in the spatial patterns of forest cover over time by means of selected landscape metrics.

\subsection{Methods}

\subsubsection{Study area}

Loja and Zamora Chinchipe provinces are located between $78^{\circ}$ and $80^{\circ} \mathrm{W}$ and $3^{\circ}$ and $5^{\circ} \mathrm{S}$ and cover approximately $21,631 \mathrm{~km}^{2}$ in South Ecuador (Figure 2.1). Both provinces are geographically separated by the Cordillera Real, the eastern range of the Ecuadorian Andes. This region is a topographically diverse area where elevation ranges from 105 to $3,866 \mathrm{~m}$ a.s.l. (Farr et al., 2007). The thermal gradient ranges from $7{ }^{\circ} \mathrm{C}$ to $25^{\circ} \mathrm{C}$ mean annual temperature. It depends not only on elevation but also on the exposition of the macro- and meso-relief with respect to the prevailing wind direction (Maldonado, 2002; MAE, 2012). 
The precipitation regime is determined by the Andean ridge; the eastern Andean slopes are moist in contrast to the (semi-) arid climate of the western side of the range (Ritcher, 2003; Emck, 2007). The precipitation ranges from $500 \mathrm{~mm}$ to $8,000 \mathrm{~mm}$ per year; some intermountain dry areas receive less than $500 \mathrm{~mm}$ of annual precipitation (Emck, 2007; Bendix and Lauer, 1992). Soil conditions are highly variable, depending on elevation, bedrock and climate (e.g. Wolf et al., 2011).

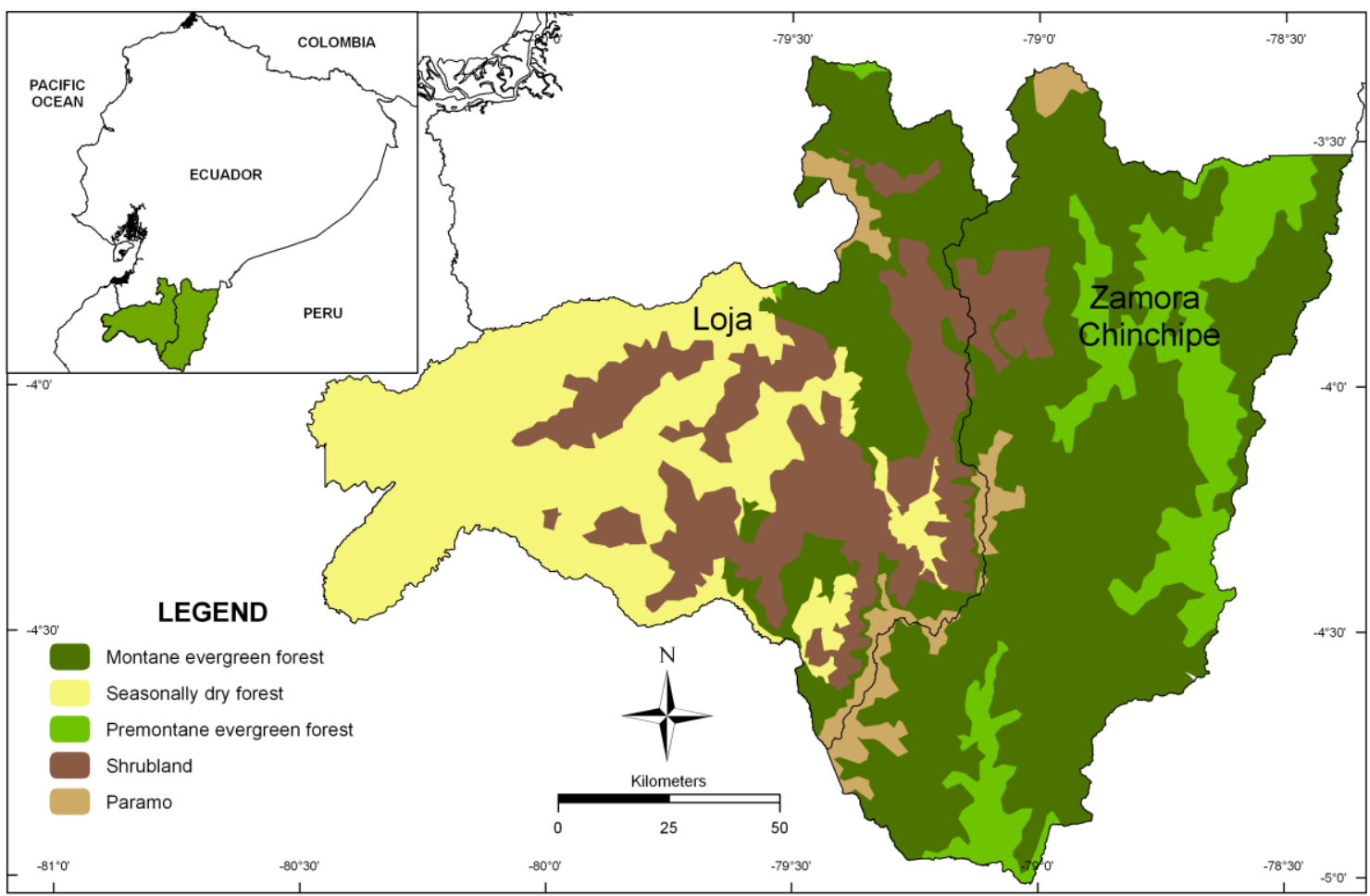

Figure 2.1 Location of the study area. Distribution of the main natural vegetation categories in the Loja and Zamora Chinchipe Provinces in South Ecuador.

\subsubsection{Geographic data}

Historic land cover patterns for 1976 and 1989 were obtained from black and white aerial photographs (scale 1:60,000) because the availability of historic satellite images in general and cloud-free satellite scenes in particular is limited for the study area. A total of 486 
aerial photographs were used to obtain the land cover mosaic for the first study year (1976) and 469 aerial photographs for the second study year (1989). The aerial photographs were provided by the National Mapping Agency (IGM) from the government projects Carta Nacional 1976 - 1978 and Carta Nacional 1986 - 1989.

The land cover map for the third study year (2008) was derived from Advanced Spaceborne Thermal Emission and Reflection Radiometer Data (ASTER, $15 \mathrm{~m}$ resolution) scenes type 1B. A total of 17 scenes $(60 \times 60 \mathrm{~km})$ were acquired from the USGS GloVis portal. To obtain a complete scenes mosaic with a cloud cover of less than $20 \%$, we used scenes from three consecutive years (2006 - 2008), because especially the eastern part of the study area is covered with clouds most of the year (Keating, 1998; Bendix et al., 2005).

For pre-processing and land cover classification of aerial photographs and satellite images (described below), we used maps of roads and rivers derived from 55 topographic maps (IGM, 2010), a 90-m digital elevation model (Farr et al., 2007) and all available land use maps of smaller areas within our study region from different periods (Keating, 1998; Torracchi et al., 2012; Göttlicher et al., 2009).

\subsubsection{Land-cover classification}

Patches of natural forests existing in 1976 and 1989 were drawn from aerial photographs with the use of a stereoscope. To distinguish between the three categories natural cover areas, other cover types (non-natural covers) and cloud-covered areas, we used a visual interpretation using color, texture and context criteria (Chuvieco, 2010). All drawn polygons were scanned, digitized and individually geo-referenced. A minimum of 15 control points were used to reference each aerial image, using well-defined permanent objects such as rivers and road intersections. Polygons that were not consistent with the mosaic were redrawn. The interpreted land cover mosaics of 1976 and 1989 were transferred to a vector map to ArcGIS (9.2) (Mendoza and Etter, 2002).

Land cover maps from 2008 for the Loja and Zamora Chinchipe provinces (Cueva and Chalán, 2010; Tapia-Armijos et al., 2011) were derived from Aster satellite images, using the first three bands. ASTER scenes were acquired with an initial radiometric and 
geometric calibration (Abrams et al., 2002). In mountainous areas, it is necessary to integrate ancillary data (Toutin, 2004; Schowengerdt, 2007). Thus, the Aster scenes were ortho-rectified with a DEM $(90 \mathrm{~m})$ and the river network using a second-order polynomial model (Toutin, 2004; Pala and Pons, 1995). Atmospheric correction was applied to all scenes using the Cost Model (Chávez, 1996) which incorporates deep object subtraction, Rayleigh dispersion and a procedure that calculates the absorption effects by atmospheric gasses. The topographic correction was made using the IDRISI SELVA hillshade control procedure (Eastman, 2012) with a DEM (SRTM $90 \mathrm{~m}$ ) to remove differences in solar illumination influenced by relief, one of the principal problems arising in the analysis of satellite scenes in mountainous areas with rugged topography (Millette et al., 1995; Riaño et al., 2003).

A total of 630 (non-randomly distributed) ground control points were recorded in order to conduct a supervised classification to distinguish the "natural cover" areas from non-natural cover areas called "other covers" (which include crops, pastures, plantations, degraded forest and urban areas). The maximum likelihood criterion was used to assist in the classification of overlapping signatures, in which pixels were assigned to the class of highest probability (Echeverria et al., 2006). The selection of the ground-truthing points was limited by site accessibility that depended on available roads and topography.

In order to facilitate the discrimination of difficult covers, both historical aerial photographs and Aster scenes were classified following specific criteria which considered the characteristics of the studied landscape in each period; the criteria are detailed below:

\section{Pastures}

In Ecuador natural grasslands are characteristic of paramo vegetation and specifically for South Ecuador they are restricted to areas above $2800 \mathrm{~m}$ a.s.l. (Sierra, 1999). We assumed that pastures below $2800 \mathrm{~m}$ a.s.l. in the study area are the result of human activities and thus included them under "non-natural covers". Paramo usually presents a continuous surface (Figure S1A) while pastures exhibit highly parceled patterns (Figure S1B). Additionally, pastures were distinguished from paramo by the generally brighter gray tones in the aerial photographs (Figure S1C). 


\section{Tree plantations}

In the eastern part of the study area there are still no forest plantations, in the western part, there are plantations of pines (mostly Pinus patula) and eucalypts (Eucalyptus spp.). In the aerial photographs, tree plantations show lower densities (Figure S2A) and a lighter tone compared to natural forests and uniform spatial pattern as consequence of the equally spaced trees within rows (Figure S2B).

\section{Secondary and degraded forests}

In this study, we do not discriminate between primary and secondary forest (it is not possible using aerial photographs), we were more interested in discriminate the forest without human intervention from the forest with human intervention. Thus, we used forest density to classify forest as natural covers or other covers (Figure S3A). Dense forest was classified as natural cover (Figure S3B), and those forests with some grade of intervention (e.g. areas of forest with gaps resulting from selective logging) were considered within class other covers (non-natural covers) (Figure S3C).

\subsubsection{Accuracy assessment}

The visual interpretation of the land cover maps of 1976 and 1989 was checked by a person with excellent knowledge of the covered localities and validated against other thematic maps of smaller areas (Keating, 1998; Torracchi et al., 2012; Göttlicher et al., 2009). The validation of historical land cover at ground truthing points was impossible due to the changes registered in the landscape since the photos were taken.

To validate the precision with which land cover map of 2008 discriminated natural cover areas from other covers (non-natural covers) a new set of 541 testing ground truthing points was used. We constructed a confusion matrix to obtain the precision of the classification comparing the class identified for each sample point with the cover derived from ASTER scenes classification (Chuvieco, 2010). The resulted accuracy assessment was given by the values obtained in the global accuracy, producer's accuracy, and user's accuracy measures and the kappa index (Equation 1) where $\pi_{0}$ is and observational probability of agreement 
and $\pi \mathrm{e}$ is a hypothetical expected probability of agreement under an appropriate of baseline constraints such as total independence of observer classifications (Landis and Koch, 1977).

$$
\kappa=\frac{\pi_{0}-\pi_{e}}{1-\pi_{e}}
$$

\subsubsection{Deforestation at regional level and form the different forest types}

In contrast to other studies (e.g. Aide et al., 2013) we only quantify the loss of original forest area and disregard areas of regenerating or secondary forests. Our experience is that deforested areas in the study area do not attain the structural attributes or species composition of undisturbed forests even after some decades of natural succession (Homeier et al., 2013).

Deforestation analyses were conducted at two levels. At regional level, we calculated the annual deforestation rates for each period $(1976$ - 1989; 1989 - 2008) using the differences in the natural cover area. In addition, we calculated the annual deforestation rates for the principal natural forest types in the region.

We used the spatial information of the vegetation classification map for Ecuador proposed by Sierra et al. (1999), and then simplified the categories according to the classifications proposed by Balslev and Øllgaard (2002) and by Homeier et al. (2008) (Table 2.1). 
Table 2.1 Description of the natural vegetation categories used in this study, combining the vegetation classifications proposed for South Ecuador by Balslev \& Øllgaard (2002), Homeier et al. (2008) and Sierra (1999).

\begin{tabular}{|c|c|c|}
\hline $\begin{array}{c}\text { CATEGORY } \\
\text { (Balslev \& } \\
\text { Øllgaard, 2002; } \\
\text { Homeier et al., } \\
\text { 2008) }\end{array}$ & DESCRIPTION & $\begin{array}{l}\text { CORRESPONDENT } \\
\text { CATEGORY } \\
\text { (Sierra; 1999) }\end{array}$ \\
\hline $\begin{array}{l}\text { Premontane } \\
\text { evergreen forest } \\
(\mathrm{PEF})\end{array}$ & $\begin{array}{l}\text { Species -rich forest growing } \\
\text { from } 500 \mathrm{~m} \text { to } 1,300 \mathrm{~m} \text { a.s.l. } \\
\text { being characteristic for the } \\
\text { eastern escarpment of the } \\
\text { Andes. Maximum tree height is } \\
30-40 \mathrm{~m} \text {. }\end{array}$ & $\begin{array}{l}\text { Amazon foothill evergreen forest, } \\
\text { Coastal foothill evergreen forest }\end{array}$ \\
\hline $\begin{array}{l}\text { Montane } \\
\text { evergreen forest } \\
(\mathrm{MEF})\end{array}$ & $\begin{array}{l}\text { Forest growing from } 1,300 \mathrm{~m} \text { to } \\
3,100 \text { a.s.l. being } \\
\text { characterized by a high } \\
\text { diversity and abundance of } \\
\text { epiphytes. The trees reach up to } \\
30 \mathrm{~m} \text { in the lowermost areas and } \\
\text { to less than } 10 \mathrm{~m} \text { in the highest } \\
\text { areas. These forests are mainly } \\
\text { located on the slopes of the } \\
\text { Cordillera Real. }\end{array}$ & $\begin{array}{l}\text { Western Andes upper montane } \\
\text { evergreen forest, Eastern Andes } \\
\text { upper montane evergreen forest, } \\
\text { Amazon cordillera lower montane } \\
\text { evergreen forest, Western Andes } \\
\text { lower montane evergreen forest, } \\
\text { Southeastern Andes lower montane } \\
\text { evergreen forest, Amazon } \\
\text { cordillera montane evergreen } \\
\text { forest, Western Andes montane } \\
\text { cloud forest, Eastern Andes } \\
\text { montane cloud forest. }\end{array}$ \\
\hline Paramo (PA) & $\begin{array}{l}\text { Contains two types of paramo: } \\
\text { herbaceous and shrub paramo. } \\
\text { Both are found above } 2,800 \mathrm{~m} \\
\text { a.s.1. The shrub paramo is a } \\
\text { natural cover unique for South } \\
\text { Ecuador. }\end{array}$ & $\begin{array}{l}\text { Herbaceous paramo, Dry paramo, } \\
\text { Southern Andes shrub páramo }\end{array}$ \\
\hline Shrubland (SL) & $\begin{array}{l}\text { Vegetation characteristic of } \\
\text { interandean valleys between } 1 \\
200 \text { and } 3,000 \mathrm{~m} \text { a.s.l. and the } \\
\text { western slope of the Andes } \\
\text { below } 1,800 \mathrm{~m} \text { a.s.l. This } \\
\text { category includes dry and semi- } \\
\text { dry shrublands which differ in }\end{array}$ & $\begin{array}{l}\text { Southern Andes montane humid } \\
\text { shrub, Southern Andes montane } \\
\text { dry shrub }\end{array}$ \\
\hline
\end{tabular}


density and composition of species.

Located in the western part of the study area, where annual precipitation ranges from 500 to Seasonally dry $2,500 \mathrm{~mm}$ with a long period of forest (SDF) drought. This category includes dry deciduous and semideciduous forests which all grow below 1,000 m a.s.1.
Coastal foothill deciduous forest, Coastal lowland deciduous forest, Western Andes lower montane semi deciduous forest, Coastal foothill semi deciduous forest, Coastal lowland semi deciduous forest.

Both analyses excluded the surface covered by paramo since this vegetation type is not dominated by trees. To obtain deforestation rates, we used the compound-interest-rate formula (Equation 2) that was proposed by Puyravaud (Puyravaud, 2003) and used in similar studies (Echeverria et al., 2006; Cayuela et al., 2006), where $A_{1}$ and $A_{2}$ are the area cover by natural forest at time $t_{1}$ and $t_{2}$, respectively and $P$ is the annual deforestation rate.

$$
P=\frac{100}{t_{2}-t_{1}} \ln \frac{A_{2}}{A_{1}}
$$

The presence of areas with clouds and shadows in both aerial photographs and Aster scenes produced areas without information. A mask was generated with all the areas without information from any of the three periods. This mask was extracted from each period in order to keep the analyzed area comparable.

\subsubsection{Change detection analysis}

A post-classification change-detection methodology was used for investigating to what land cover type the natural forest areas were transformed. This approximation used the thematic maps obtained after land cover classification to implement a comparison pixel by pixel between two periods maps (Macleod and Congalton; 1998). For this analysis, first we calculate how much surface of the natural cover in 1976 was converted to pastures, crops, degraded forest, plantations and urban areas in 2008, using as a first scene the land cover map of 1976 and as the final scene the categories representing non-natural covers in the 
land cover map of 2008.Second, we calculate how much area of the different vegetation types was converted to the same non-natural covers used above (pastures, crops, degraded forest, plantations, and urban areas) but in this case we use as a first scene the reclassified map that shown the area covered by the different vegetation types in 1976.

\subsubsection{Fragmentation analysis}

A set of key landscape metrics was used to quantify and compare the spatial configuration of native forest fragments, taking into account that the selected metrics did not include redundant information (Armenteras et al., 2003). We used the program FRAGSTATS 3.4 (McGarigal et al., 2002) to calculate the following parameters: (1) the number of fragments of natural forest (PN: Patch number); (2) area of each individual patch (PA: Patch area); (3) the percentage of the landscape occupied by the largest fragment of natural forest (LPI: Largest patch index); (4) the mean size of natural forest patches (MPS: mean patch size); (5) the number of patches per 100 ha (PD: Patch density; (6) the degree of isolation of natural forest patches resulting from measure the ratio between the size and proximity of all patches whose edges are within $1 \mathrm{~km}$ of the focal patch (MPI: Mean proximity index); (7) the total patch size remaining after removing a specific buffer edge (TCA: Total core area); 8) the complexity of patch shapes compared to a standard shape (MSI: Mean shape index) and 9) the sum of the lengths of all edge segments in the landscape (TE: Total edge length).

\subsection{Results}

\subsubsection{Accuracy assessment}

For the validation of the 2008 land cover map, we used a confusion matrix (Table 2.2). According to Foody (2002), the overall accuracy shows the percentage of cases correctly allocated. Our results showed an overall accuracy of 92.4\%, which means that the 2008 land cover classification had a high performance to discriminate the pixels with natural cover from those with other covers (non-natural covers). 94.5\% of the areas classified as natural cover were natural cover, and $90.3 \%$ of the areas classified as other covers were other covers. 
According to Congalton (1991), the Kappa index could be considered as a powerful technique to provide accuracy information derived from a confusion matrix. For this study, the Kappa index was 0.84 which means that the land cover classification for 2008 could be considered as almost perfect according to the parameters proposed by Landis and Koch (1977).

Table 2.2 Confusion matrix obtained from the accuracy assessment of the 2008 land cover map of South Ecuador.

\begin{tabular}{lccccc}
\hline \hline & \multicolumn{3}{c}{ REFERENCE } & & \\
\cline { 2 - 4 } \multicolumn{1}{c}{ CLASSIFIED } & $\begin{array}{c}\text { Natural } \\
\text { Cover }\end{array}$ & $\begin{array}{c}\text { Other } \\
\text { Covers }\end{array}$ & Total & $\begin{array}{c}\text { User's } \\
\text { accuracy }\end{array}$ & $\begin{array}{c}\text { Commission } \\
\text { error }\end{array}$ \\
\hline \hline Natural Cover & 257 & 15 & 272 & 94.49 & 5.51 \\
Other Covers & 26 & 243 & 269 & 90.33 & 9.67 \\
Total & 283 & 258 & 541 & & \\
Producer's accuracy & 90.81 & 94.19 & & & \\
Omission error & 9.19 & 5.81 & & & \\
Overall accuracy & 0.92 & & & & \\
\hline \hline
\end{tabular}

\subsubsection{Deforestation and land-cover change patterns}

Changes in land cover (Table 2.3) were derived from the land cover maps of 1976, 1989 and 2008 (Figure 2.2). The area covered by original vegetation decreased during this time by approximately $46 \%$, from $19,500 \mathrm{~km}^{2}$ in 1976 to $10,550 \mathrm{~km}^{2}$ in 2008 . The annual deforestation rate in South Ecuador's forest area for the period from 1976 - 1989 was $0.75 \%$; it increased considerably to $2.86 \%$ in the 1989 - 2008 period. The average deforestation rate for the entire 32 -yr-long study period was $2.01 \%$. Premontane evergreen forest and shrubland were the vegetation types that suffered the highest conversion rate during the whole study period (Figure 2.3, Table 2.3). 
Table 2.3 Area covered by different natural forest types, other covers (non-natural covers) and clouds in 1976, 1989 and 2008 in South Ecuador.

\begin{tabular}{|c|c|c|c|c|c|c|}
\hline \multirow{2}{*}{$\begin{array}{c}\text { YEAR } \\
\text { COVER TYPE }\end{array}$} & \multicolumn{2}{|c|}{1976} & \multicolumn{2}{|c|}{1989} & \multicolumn{2}{|c|}{2008} \\
\hline & $\left(\mathrm{km}^{2}\right)$ & $(\%)$ & $\left(\mathbf{k m}^{2}\right)$ & $(\%)$ & $\left(\mathbf{k m}^{2}\right)$ & $(\%)$ \\
\hline $\begin{array}{l}\text { Premontane } \\
\text { evergreen forest } \\
\text { (PEF) }\end{array}$ & $2,033.58$ & 9 & $1,714.99$ & 8 & 279.3 & 1 \\
\hline $\begin{array}{l}\text { Montane } \\
\text { evergreen forest } \\
\text { (MEF) }\end{array}$ & $9,221.08$ & 43 & $8,605.03$ & 40 & $5,150.71$ & 24 \\
\hline Paramo (PA) & 714.83 & 3 & 710.72 & 3 & 662.83 & 3 \\
\hline Shrubland (SL) & $2,966,51$ & 14 & $2,526.06$ & 12 & $1,361.86$ & 6 \\
\hline $\begin{array}{l}\text { Seasonally dry } \\
\text { forest (SDF) }\end{array}$ & $4,563.93$ & 21 & $4,183.76$ & 19 & $3,097.5$ & 14 \\
\hline Clouds (CL) & 272.82 & 1 & 272.82 & 1 & 272.82 & 1 \\
\hline $\begin{array}{l}\text { Other covers } \\
(\mathrm{OC})\end{array}$ & $1,858.25$ & 9 & $3,617.62$ & 17 & $10,805.98$ & 50 \\
\hline Total & $21,631.0$ & 100 & $21,631.0$ & 100 & $21,631.0$ & 100 \\
\hline
\end{tabular}

During the 32 years of the study period, $3,954 \mathrm{~km}^{2}$ of natural forest have been converted to degraded forest, a similar area $\left(3,654 \mathrm{~km}^{2}\right)$ has been converted to pastures, and another 631 $\mathrm{km}^{2}$ to crop lands. The change detection analysis (Table 2.4) shows that the premontane evergreen forest and the montane evergreen forest were mainly transformed to degraded forest (51\% and $27 \%$ of the initial area, respectively), and the shrubland and dry forest were mostly converted to pastures (33\% and $18 \%$, respectively). The only natural forest type with a relevant transformation to crops was the dry forest $(9 \%)$. Conversion of natural forest to plantations or urban areas was of minor importance. 


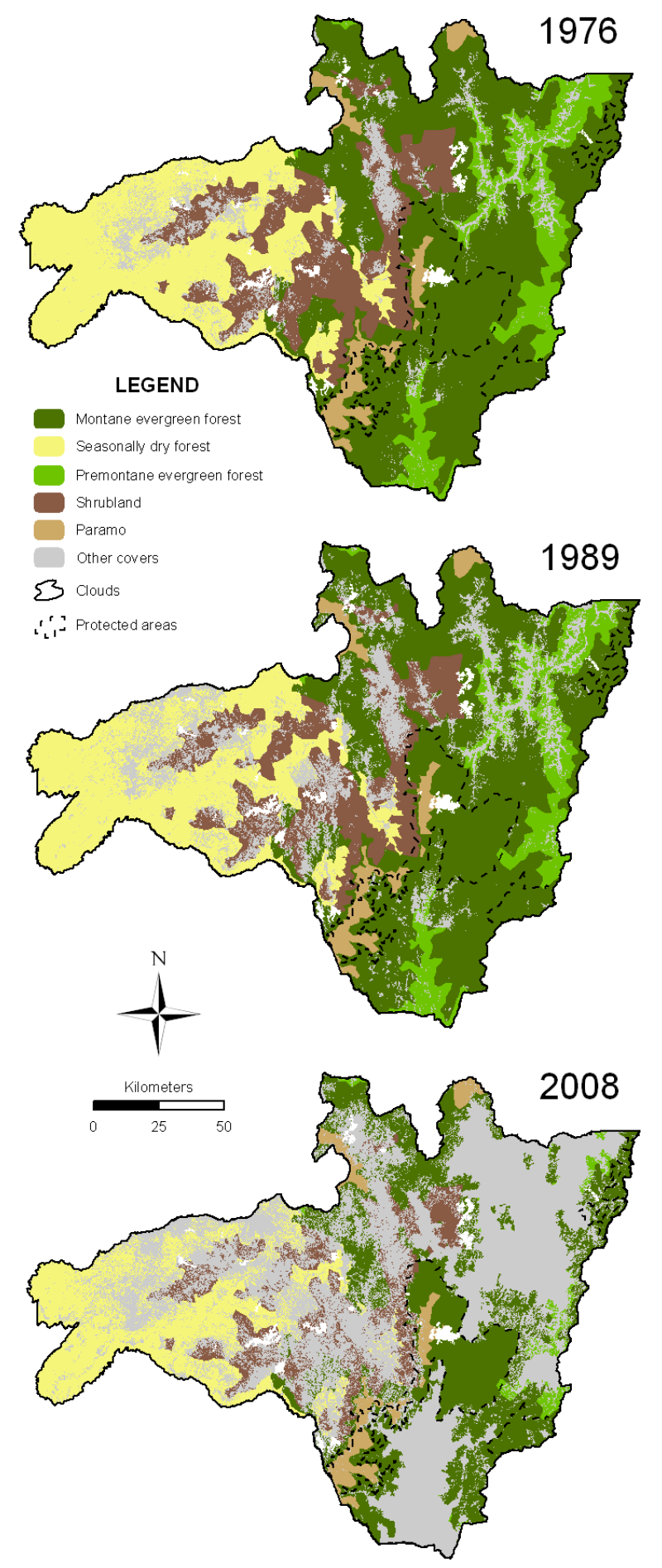

Figure 2.2 Land cover maps for years 1976, 1989, 2008. Maps display the spatial distribution patterns of the different land cover types in South Ecuador for the three studied years. The black dashed polygons show the boundaries of the protected areas that belong to the national system of protected areas (PANE). 


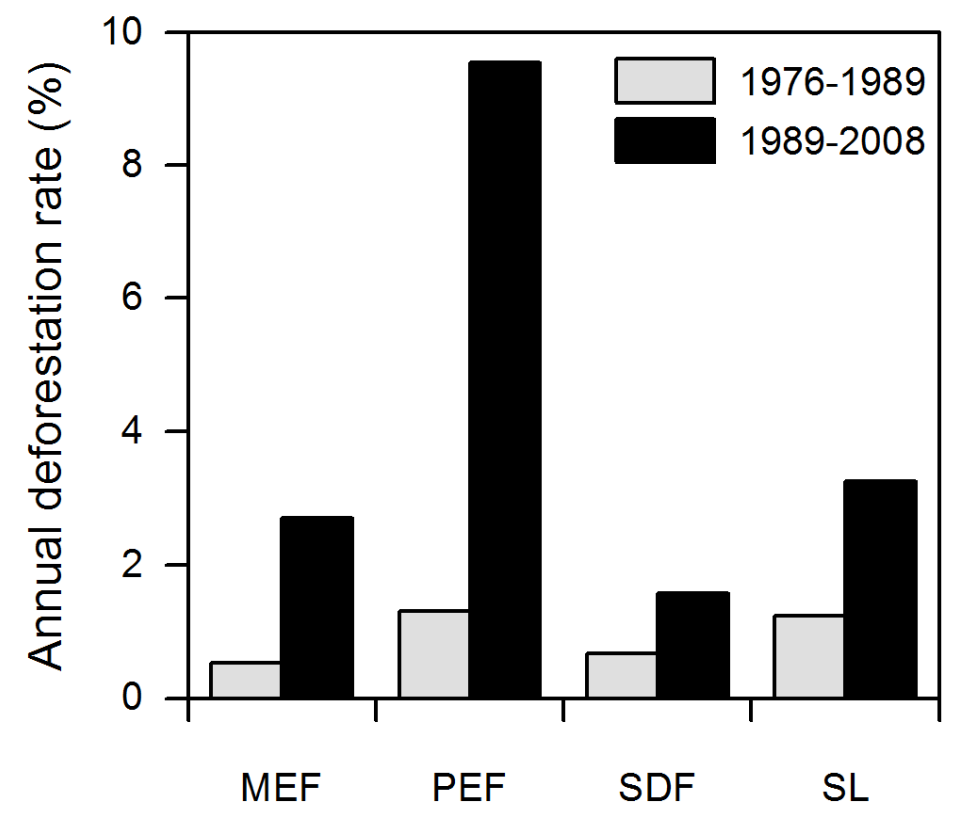

Figure 2.3 Annual deforestation rates for different vegetation types in South Ecuador. Annual deforestation rates in four natural vegetation types in the study area for the periods 1976 1989 and $1989-2008 . \mathrm{MEF}=$ Montane evergreen forest, $\mathrm{PEF}$ $=$ Premontane evergreen forest, $\mathrm{SDF}=$ Seasonally dry forest, $\mathrm{SL}=$ Shrubland 
Table 2.4 Changes of natural vegetation types to other covers in South Ecuador since 1976 to 2008.

\begin{tabular}{|c|c|c|c|c|c|c|c|c|c|c|}
\hline \multirow[t]{2}{*}{ Other Covers } & \multicolumn{2}{|l|}{ Crops } & \multicolumn{2}{|c|}{ Pastures } & \multicolumn{2}{|c|}{ Plantations } & \multicolumn{2}{|c|}{ Degraded Forest } & \multicolumn{2}{|c|}{ " Urban Area } \\
\hline & $\begin{array}{c}\text { Total } \\
\text { Converted } \\
\text { Surface }\left(\mathrm{km}^{2}\right)\end{array}$ & $\%$ & $\begin{array}{c}\text { Total } \\
\text { Converted } \\
\text { Surface }\left(\mathrm{km}^{2}\right)\end{array}$ & $\%$ & $\begin{array}{c}\text { Total } \\
\text { Converted } \\
\text { Surface }\left(\mathrm{km}^{2}\right)\end{array}$ & $\%$ & $\begin{array}{c}\text { Total } \\
\text { Converted } \\
\text { Surface }\left(\mathrm{km}^{2}\right)\end{array}$ & $\%$ & $\begin{array}{c}\text { Total } \\
\text { Converted } \\
\text { Surface }\left(\mathrm{km}^{2}\right)\end{array}$ & $\%$ \\
\hline $\begin{array}{l}\text { Premontane } \\
\text { evergreen forest } \\
(\text { PEF })\end{array}$ & 97 & 1.1 & 1,218 & 13.2 & 18 & 0.2 & 2,444 & 26.5 & 5 & 0.1 \\
\hline $\begin{array}{l}\text { Seasonally dry } \\
\text { forest (SDF) }\end{array}$ & 19 & 0.9 & 613 & 30.1 & 0 & 0.0 & 1,041 & 51.2 & 3 & 0.1 \\
\hline Shrubland (SL) & 439 & 9.6 & 832 & 18.2 & 1 & 0.0 & 87 & 1.9 & 10 & 0.2 \\
\hline Paramo (PA) & 75 & 2.5 & 980 & 33.0 & 19 & 0.6 & 354 & 11.9 & 3 & 0.1 \\
\hline $\begin{array}{l}\text { Montane } \\
\text { evergreen forest } \\
\text { (MEF) }\end{array}$ & 1 & 0.1 & 11 & 1.6 & 3 & 0.4 & 28 & 3.9 & 0 & 0.0 \\
\hline Total & 631 & 14.2 & 3,653 & 96.2 & 41 & 1.2 & 3,954 & 95.4 & 21 & 0.5 \\
\hline
\end{tabular}




\subsubsection{Fragmentation patterns}

The total number of forest patches increased from 1957 in 1976 to 3,831 in 1989 , and to 9,988 in 2008 representing a 500\% increase relative to the number of fragments present in 1976 (Figure 2.4). In 1976, the landscape contained one large continuous forest patch of $19,296 \mathrm{~km}^{2}$ that occupied $89 \%$ of the study area, while the remaining natural forest area was distributed to many small fragments of less than $1 \mathrm{~km}^{2}$ size. In 1989, the largest natural forest patch still occupied $80 \%$ of the landscape, but in 2008, this largest patch had been greatly reduced to not more than $19 \%$ of the study area. The remaining natural forest area is today concentrated in a few patches of more than $100 \mathrm{~km}^{2}$ size and a large number of small fragments with less than $1 \mathrm{~km}^{2}$. Mean forest fragment size decreased more than ten-fold from $15.1 \mathrm{~km}^{2}$ in 1976 to $1.4 \mathrm{~km}^{2}$ in 2008 , which mostly results from the dissection and conversion of the initial large patch.

The process of fragmentation is further evident from the marked increase in patch density from 7 to 72 patches per $100 \mathrm{~km}^{2}$ (Table 2.5). The increasing total edge length (from $19,278 \mathrm{~km}$ to $51,109 \mathrm{~km}$ ) and the growing mean shape index value (from 1.5 to 1.69 ) indicate increasing irregularity in the shape of natural forest patches and an increasing susceptibility to potential edge effects. The total core area of remaining natural forest considering a buffer zone of $300 \mathrm{~m}$ decreased by $70 \%$ from 1976 to 2008 to less than 5000 $\mathrm{km}^{2}$ today (Table 2.5 ). The mean core area per forest patch was reduced from $25 \mathrm{~km}^{2}$ (1976) to $12 \mathrm{~km}^{2}$ (1989) and just $3 \mathrm{~km}^{2}$ (2008).

Another result of fragmentation is the increasing isolation of natural forest patches due to the replacement of natural forest by other land cover types. According to McGarigal (2002) the mean proximity index, as a measure of the grade of isolation, decreased since the neighborhood is less occupied by natural forest patches. In this study, this particularly occurred in the second period after 1989 (¡Error! No se encuentra el origen de la referencia.). 


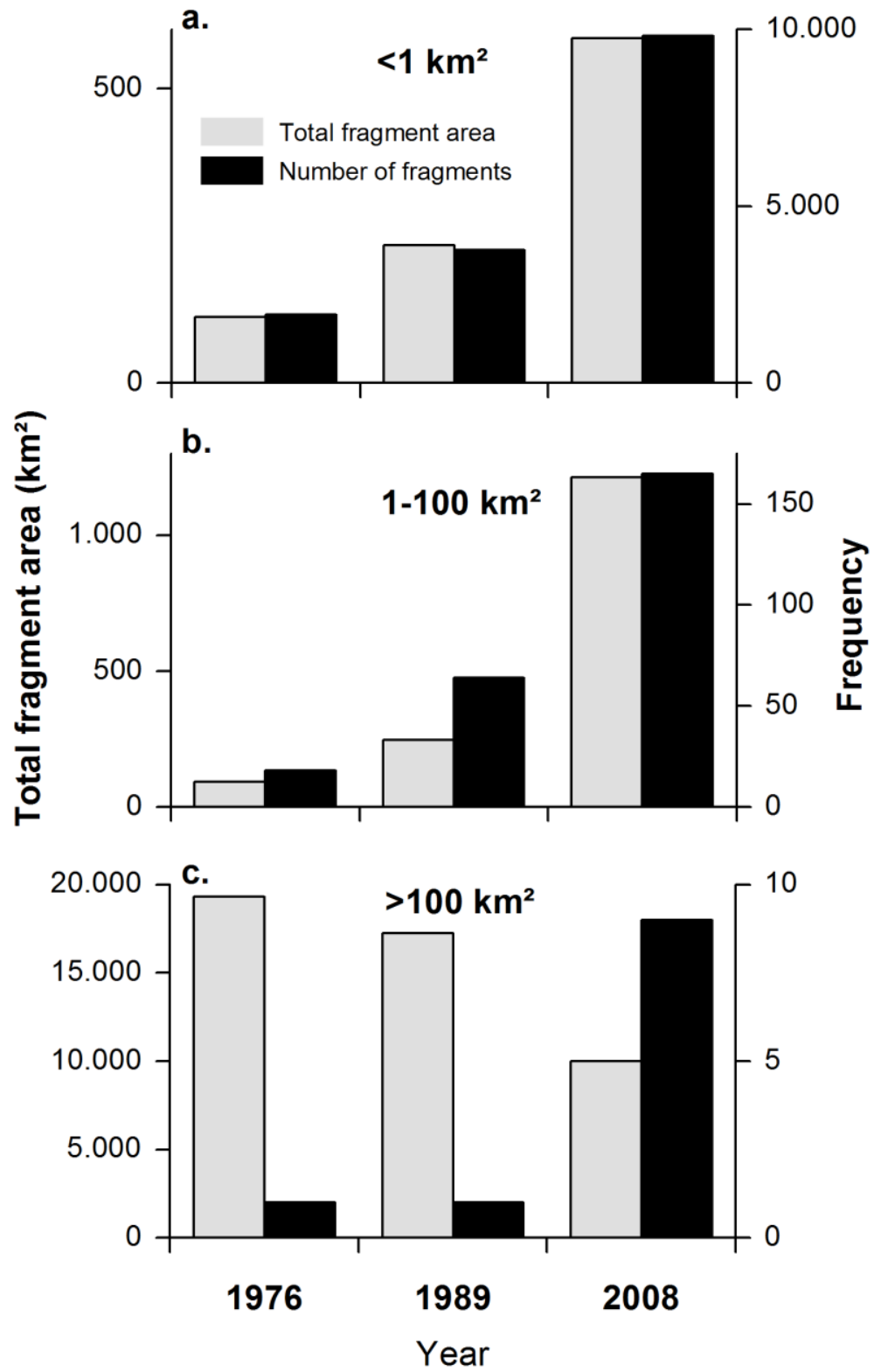

Figure 2.4 Variation of forest fragment size and total fragment area for 1976, 1989 and 2008. The figure shows the increase in the number of forest fragments (black bars) and the decreased in the cumulative area of the forest fragments (gray bars) of three different fragment size classes $\left(<1 \mathrm{~km}^{2}, 1-100 \mathrm{~km}^{2},>100 \mathrm{~km}^{2}\right)$ in each studied year. 
Table 2.5 Changes in the spatial configuration of natural forests in South Ecuador during the period from 1976 to 2008 .

\begin{tabular}{lrrr}
\hline \hline \multicolumn{1}{c}{ LANDSCAPE INDICES } & \multicolumn{1}{c}{$\mathbf{1 9 7 6}$} & $\mathbf{1 9 8 9}$ & $\mathbf{2 0 0 8}$ \\
\hline \hline Total area of forest $\left(\mathrm{km}^{2}\right)$ & 19,500 & 17,741 & 10,550 \\
Total number of patches & 1,958 & 3,832 & 9,988 \\
Mean patch size $\left(\mathrm{km}^{2}\right)$ & 15.1 & 6.3 & 1.4 \\
Patch density (number of patches $\left./ 100 \mathrm{~km}^{2}\right)$ & 7 & 16 & 72 \\
Largest patch index $(\%)$ & 89 & 80 & 19 \\
Total edge length $(\mathrm{km})$ & 19,278 & 30,270 & 51,109 \\
Mean shape index & 1,5 & 1,59 & 1,69 \\
Total forest core area $\left(\mathrm{km}^{2}\right)$ & 16,338 & 13,238 & 4,989 \\
Mean proximity index & $1,065,518$ & 714,713 & 87,673 \\
\hline \hline
\end{tabular}

\subsection{Discussion}

\subsubsection{Deforestation patterns}

The natural forests of South Ecuador have suffered high conversion rates during the last thirty years with an intensification of this process during the last decade. During the first studied period (1976-1989), the annual deforestation rate $(0.75 \%)$ was similar to the $0.70 \%$ decline of old-growth forest in Central Ecuador between 1963 and 1983 reported by Wunder (2000). Both rates are lower than the 1.17\% reported from the North Ecuadorian Amazon for 1973 to 1985 (Viña et al., 2004).

The discovery of oil reserves in the Ecuadorian Amazon during the 1960's led to the construction of new roads which accelerated the colonization of new areas in the lowlands. This was probably the first cause of forest loss in this zone (Mena, 2008). In contrast, South Ecuador conserved large areas of natural forests until the 1980s, mainly in the eastern part that was then sparsely inhabited and with limited accessibility.

The Ecuadorian Agrarian Reform in 1964 promoted the colonization and clearance of previously forested areas to make them productive cropland or pastures nationwide 
(Southgate and Runge, 1990). However in the studied region the small size of existing settlements and the limited accessibility to natural areas delayed deforestation until recently.

We found that the annual deforestation rate increased considerably during the $1989-2008$ period (2.86\%), coinciding with Jokisch and Lair (2002) who observed that at national level deforestation was accelerated during the 1990's. During this period, the rate observed in this study was similar to that observed in the Northwest of the country (Lopez et al., 2010: $2.2 \%$ in the Santiago and Cayapas rivers watersheds during $1993-2001$ period), and half the rate observed in the Northeastern Amazon (Pan et al., 2004: 4.73\% in Sucumbíos during the period 1986 - 1999). We assume that population growth combined with the expansion of the road system in South Ecuador (starting from the year 2000) increased the accessibility of until then unexplored areas and additionally made profitable the extraction of timber at lower cost (Peters et al., 2013).

In the study area, deforestation is principally concentrated in the bottoms of the valleys and lower slopes, with many small forest patches in varying states of degradation remaining within the most heavily impacted areas. Similar to other Latin American countries, the deforested areas are mainly used as pastures (Sierra, 2000). Our results show that the Andean pre-montane evergreen forest, the Seasonally dry forest, and the Shrubland had been converted for large-scale cattle ranching documenting that this is not only a characteristic feature of the humid Amazon lowland in Brazil, Ecuador and Bolivia as reported by Geist and Lambin (2002). Andean pre-montane evergreen forest apparently has optimal thermal conditions for cattle ranching, but due to the low soil fertility in the study area, many pastures are not very productive and therefore are frequently abandoned after a few years (Homeier et al., 2013). With regards to the seasonally dry forest, the establishment of pastures for cattle ranching seems to be the leading factor of tropical dry forest conversion (Janzen, 1988; Trejo and Dirzo, 2000). Kauffman et al. (2003) estimated that the highest aboveground biomass losses in a Mexican dry forests occurred as a result of biomass burning, which is a common practice of peasants in order to convert dry forest to pastures. At the same time and in the short term, forest burning increases the $\mathrm{pH}$ and 
inorganic nitrogen of the soil, reducing the capacity to adaptation of dry forest native species and increasing the vulnerability to alien species invasion (Ellingson et al., 2000).

In the eastern part of the study area the deforestation front seems to have moved upslope in the valleys through the different forest belts (e.g. the annual deforestation rate for the montane evergreen forest increased in the second survey period from $0.5 \%$ to $2.7 \%$ which is related to areas where the pre-montane evergreen forest had already been transformed before). In the western part, where seasonally dry forest and shrubland predominated there is not a clear frontline and the deforestation seems to result from diffuse smallholder activities. Precisely, these smallholders' activities and the absence of large pasture or crop areas had produced a highly dynamic landscape where shrubland patches are scattered through the flat areas and the hill slopes. The shrubland showed the second highest deforestation rate in the study area. As shown by Schulz et al. (Schulz et al., 2010) the deforestation process in shrubland is commonly characterized by the transition of shrubland to agricultural land followed by a later conversion of agricultural land to pasture or bare lands.

\subsubsection{Fragmentation patterns}

In addition to the overall reduction of forest area, we found an increase in the number, isolation, and irregularity of forest patches and a decrease in the size of patches reflecting the ongoing fragmentation of forest habitats. The intensification of forest fragmentation since 1989 seems to be related to the increase in accessibility that was mainly caused by the construction of new highways and rural roads. More fragmented woodlands (e.g. areas with more isolated, irregular and smaller fragments) usually occur near roads and rivers and towns and cities where the human population has increased considerably during the last decades. Hawbaker et al. (2006) demonstrated a positive relationship between the increases in road density and the changes in landscape patterns (e.g. patch area and patch shape) and house density. In South Ecuador, there are no specific studies that show this relation, but Peters et al. (2013) mentioned the decisive role that roads construction had on land reclamation in Ecuador and thereby on the changes observed in landscape patterns. 
The factors related to the fragmentation process go beyond physical factors like road construction. Heterogeneity of socio-economic, demographic and other factors results in different types of changes in the landscape patterns. In the eastern part of South Ecuador, higher poverty and a shortage of adult labor result in the dominance of cattle ranching. Thus, the farms are characterized by large pasture areas around dwellings, small areas used for subsistence agriculture, and forest patches $\left(<20 \mathrm{~km}^{2}\right)$ persist only in the most inaccessible areas of the farms. In contrast, Marquette (Marquette, 1998) noted that in north-eastern Ecuador, where a combination of small - scale agricultural activity and cattle ranching predominates, approximately $80 \%$ of small farmers clear only small areas of forest. In Ecuadorian dry ecosystems the major remaining surface of the forest is distributed to patches of more than $10 \mathrm{~km}^{2}$ that does not mean that fragmentation is low but rather than deforestation is the dominant process (Portillo-Quintero and Sánchez-Azofeifa, 2010).

In the study area, the largest conserved forest patches persisted in 2008 in areas with a protection status such as national protected areas, private reserves, or communitarian protected forests, highlighting the importance of in situ conservation strategies. However, if the high deforestation rates are maintained, and fragmentation is going on, the remaining forest will soon be reduced to isolated forest patches that cannot fully meet their conservation purpose (DeFries et al., 2005) with a reduced ecological functionality and capacity to conserve species richness (e.g. Hansen and DeFries, 2007; Knowlton and Graham, 2011). It reveals the importance to increase the protected area, especially in the dry forest where conservation must be considered a prior task for Ecuador because of the high levels of endemism and the small extent of this natural vegetation type in the country (Portillo-Quintero and Sánchez-Azofeifa, 2010; Espinosa et al., 2012).

The progressive fragmentation in the study area may have serious consequences for local species with high requirements to their habitat (e.g. charismatic species such as Tremarctos ornatus, Puma concolor or Tapirus pinchaque which often require available habitat areas $>2,000 \mathrm{~km}^{2}$ ) or for rare species with small population sizes and restricted geographical ranges (e.g. more than 1,000 endemic plant species are present in the area) (Kouki et al., 2001). Studies in other tropical hotspots showed that fragments of $1 \mathrm{~km}^{2}$ (approximately 
9,000 fragments in our study area) lose one-half of their species in <15 years (e.g. Ferraz et al., 2003) and that less than $50 \%$ of all midsized and large mammals persist in fragments $<5$ $\mathrm{km}^{2}$, even if the species are matrix - tolerant (e.g. Canale et al., 2012). Additionally, the loss of species results in locally impoverished and increasingly homogenized tree assemblages, where old-growth tree flora is replaced by a small subset of pioneer or successional tree species (Santos et al., 2014; Tabarelli et al., 2010; Tabarelli et al., 2012).

\subsection{Conclusions}

Improved awareness of the spatial extent, dynamics, and patterns of deforestation and forest fragmentation is urgently needed in biologically diverse areas like South Ecuador. Our study shows that this region, where only $9.8 \%$ of the surface area is under governmental protection, should be in the urgent focus of conservation initiatives, especially since new mining projects will soon open access to the larger forest tracts left in the southeastern part of the Zamora-Chinchipe province. Since there may be positive feedback between human land use, future climatic change (Brodie et al., 2012) and increasing atmospheric nutrient deposition (Homeier et al., 2012) the threats to most of the studied ecosystems are probably even larger than predicted from our land use trajectory.

\subsection{Acknowledgments}

We want to thank all the technicians that assisted with field and laboratory work (M. Valdivieso, J. González, F. Bravo and C. Prieto). We are grateful to NCI - Loja, especially to J.L. Cueva, for providing the land cover map of the Loja Province and for the support and cooperation to obtain the land cover map of Zamora Chinchipe Province. We also want to thank D. Draper for his scientific support. We appreciate the support of the National Mapping Agency IGM for officially authorize the use of the historical aerial photographs (1976-1989) according to the authorization No. IGM-2015-002 and the record No. 3148. 


\subsection{References}

Abrams M., Hook S., \& Ramachandran B. (2002). ASTER User Handbook: Advanced Spaceborne Thermal Emission and Reflection Radiometer Jet Propulsion Laboratory, Pasadena: California Institute of Technology.

Aide T.M., Clark M.L., Grau H.R., López-Carr D., Levy M.A., Redo D., et al. (2013). Deforestation and reforestation of Latin America and the Caribbean (2001-2010). Biotropica, 45, 262-271.

Armenteras D., Gast F., \& Villareal H. (2003). Andean forest fragmentation and the representativeness of protected natural areas in Eastern Andes, Colombia. Biological Conservation, 113, 245-256.

Balslev H., \& Ollgaard B. (2002). Mapa de vegetación del Sur del Ecuador. In: Aguirre Z, Madsen JE, Cotton E, Balslev, editors. Botánica Autroecuatoriana - Estudios sobre los recursos vegetales en las provincias de El Oro, Loja y Zamora Chinchipe, Ediciones ABYA YALA, Quito - Ecuador.

Barthlott W., Mutke J., Rafiqpoor D., Kier G., \& Kreft H. (2005). Global centers of vascular plant diversity Nova Acta Leopoldina, 92, 61-83.

Bendix J., \& Lauer W. (1992). Die Niederschlagsjahreszeiten in Ecuador und ihre klimadynamische Interpretation Erkunde, 46, 118-134.

Bendix J., Rollenbeck R., Göttlicher D., \& Cermak J. (2005). Cloud occurrence and cloud properties in Ecuador Climate Research, 30, 133.

Brehm G., Homeier J., Fiedler K., Kottke I., Illig J., \& Nöske N. (2008). Mountain rain forests in southern Ecuador as a hotspot of biodiversity - limited knowledge and diverging patterns. In: Beck E, Bendix J., Kottke I., Makeschin F., Mosandl R., editors. Gradients in a Tropical Mountain Ecosystem of Ecuador: Ecological Studies, Berlin: Springer; pp. 15-23. 
Brehm G., Pitkin L.M., Hilt N., \& Fiedler K. (2005). Montane Andean rain forests are a global diversity hotspot of geometrid moths. Journal of Biogeography, 32, 1621-1627.

Brodie J., Post E., \& Laurance W.F. (2012). Climate change and tropical biodiversity: a new focus. Trends in Ecology and Evolution, 27, 145-150.

Brook B.W., Sodhi N.S., \& Ng P.K. (2003). Catastrophic extinctions follow deforestation in Singapore. Nature, 424, $420-423$.

Brummit N, \& Nic Lughadha E. (2003). Biodiversity: Where's hot and where's not. Conservation Biology, 17, 1442-1448.

Canale G.R., Peres C.A., Guidorizzi C.E., Gatto C.A.F., \& Kierulff M.C.M. (2012). Pervasive defaunation of forest remnants in a tropical biodiversity hotspot. PloS ONE; 7: e41671.

Cayuela L., Rey Benayas J.M., \& Echeverría C. (2006). Clearance and fragmentation of tropical montane forests in the Highlands of Chiapas, Mexico (1975-2000). Forest Ecology and Management, 226, 208-218.

Chávez P.S. (1996). Image - Based Atmospheric Corrections - Revisited and Improved. Photogrammetric Engineering \& Remote Sensing, 62, 1025-1036.

Chuvieco E. (2010). Teledetección Ambiental. Tercera edición, Ariel Ciencia; 528 p. Barcelona:

Congalton R.G. (1991). A review of assessing the accuracy of classifications of remotely sensed data. Remote Sensing of Environment, 37, 35-46.

Cueva J., \& Chalán L. (2010). Cobertura Vegetal y Uso Actual del Suelo de la Provincia de Loja. Informe Técnico Departamento de Sistemas de Información Geográfica de Naturaleza \& Cultura Internacional, Loja: Gráficas Amazonas. 
DeFries R., Hansen A., Newton A.C., \& Hansen M.C. (2005). Increasing isolation of protected areas in tropical forests over the past twenty years. Ecological Applications, 15, 19-26.

Eastman J.R. (2012). IDRISI: The Selva Edition. Clark Labs, Clark University.

Echeverria C., Coomes D., Salas J., Rey-Benayas J.M., \& Newton A. (2006). Rapid Deforestation and fragmentation of Chilean Temperate Forests Biological. Conservation, 130, 481-494.

Ellingson L.J., Kauffman J.B., Cummings D.L., Sanford Jr R.L., Jaramillo V.J. (2000). Soil $\mathrm{N}$ dynamics associated with deforestation, biomass burning and pasture conversion in a Mexican tropical dry forest. Forest Ecology and Management, 137, 41-51.

Emck P. (2007). A climatology of South Ecuador with special focus on the major Andean ridge as Atlantic-Pacific climate divide, scholarly journal. $\mathrm{PhD}$ thesis, University of Erlangen-Nürnberg. Available at: http://opus4.kobv.de.

Espinosa C.I., De la Cruz M., Luzuriaga A.L., \& Escudero A. (2012). Bosques tropicales secos de la región Pacífico Ecuatorial: diversidad, estructura, funcionamiento e implicaciones para la conservación. Revista Ecosistemas, 21,1-2.

Eva H.D., Achard F., Beuchle R., De Miranda E., Carnoni S., Seliger, R., et al. (2012). Forest cover changes in tropical South and Central America from 1990 to 2005 and related carbon emissions and removals. Remote Sensing, 4, 1369-1391.

Fahrig L. (2002). Effect of habitat fragmentation on the extinction threshold: a synthesis. Ecological Applications, 12, 346-353.

Fahrig L. (2003). Effects of Habitat Fragmentation on Biodiversity. Annual Review of Ecology, Evolution \&. Systematics, 34, 487-515.

FAO. (2011). State of the World's forests 2011. Roma. 
Farr T.G., Rosen P.A., Caro E., Crippen R., Duren R., Hensley S., et al. (2007). The Shuttle Radar Topography Mission. Reviews of Geophysics,45(2).

Fearnside P.M., \& Laurence W.F. (2004). Tropical deforestation and greenhouse - gas emissions. Ecological Applications, 14, 982 - 986.

Ferraz G., Russell G.J., Stouffer P.C., Bierregaard R.O., \& Pimm S.L. (2003). Rates of species loss from Amazonian forest fragments. Proceedings of the National Academy of Sciences, 100, 14069-14073.

Fischer J., \& Lindermayer D. (2007). Landscape modification and habitat fragmentation: a synthesis. Global Ecology and Biogeography, 16, 265-280.

Foody G.M. (2002). Status of land cover classification accuracy assessment. Remote Sensing of Environment, 80, 185-201.

Geist H.J., \& Lambin E.F. (2002). Proximate causes and underlying driving forces of tropical deforestation: Tropical forests are disappearing as the result of many pressures, both local and regional, acting in various combinations in different geographical locations. BioScience, 52,143-150.

Göttlicher D., Obregon A., Homeier J., Rollenbeck R., Nauss T., \& Bendix J. (2009). Landcover classification in the Andes of southern Ecuador using Landsat ETM+ data as a basis for SVAT modeling. International Journal of Remote Sensing, 30, 1867-1886.

Hansen A.J., \& DeFries R. (2007). Ecological mechanisms linking protected areas to surrounding lands. Ecological Applications, 17, 974-988.

Hawbaker T.J., Radeloff V.C., Clayton M.K., Hammer R.B., \& Gonzalez-Abraham C.E. (2006). Road development, housing growth, and landscape fragmentation in northern Wisconsin: 1937-1999. Ecological Applications, 16, 1222-1237.

Homeier J., Hertel D., Camenzind T., Cumbicus N.L., Maraun M., Martinson G.O., et al. (2012). Tropical Andean forests are highly susceptible to nutrient inputs - Rapid effects 
of experimental $\mathrm{N}$ and $\mathrm{P}$ addition to an Ecuadorian montane forest. PLoS ONE, 7: e47128.

Homeier J, Werner F.A., Gawlik J., Peters T., Diertl K.J., \& Ritcher M. (2013). Plant diversity and its relevance for the provision of ecosystem services. In: Bendix J., Beck E., Bräuning A., Makeschin F., Mosandl R., Scheu S., editors. Ecosystem services, biodiversity and environmental change in a tropical mountain ecosystem of South Ecuador Ecological Studies. Springer, pp 93-106. Berlin.

Homeier J., Werner F.A., \& Gradstein S.R. (2008). Potential vegetation and floristic composition of Andean forests in South Ecuador, with a focus on the RBSF. In: Beck E., Bendix J., Kottke I., Makeschin F., Mosandl R., editors. Gradients in a Tropical Mountain Ecosystem of Ecuador: Ecological Studies. Springer, pp 87-100. Berlin.

Iñiguez-Armijos C., Leiva A., Frede H., Hampel H., \& Breuer L. (2014). Deforestation and benthic indicators: How much vegetation covers is needed to sustain healthy andean streams? PLoS ONE, 9(8): e105869.

Instituto Geográfico Militar. (2010). Cartografía Base Nacional escala1:50000.

Janzen D.H. (1988). Tropical dry forests. The most endangered major tropical ecosystem. In: Wilson E. O., editor. Biodiversity. National Academy Press, pp 130-137. Washington.

Jokisch B.D., \& Lair B.M. (2002). One last stand? Forests and change on Ecuador's Eastern Cordillera. Geographical Review, 92, 235-256.

Kauffman J.B., Steele M.D., Cummings D.L., \& Jaramillo V.J. (2003). Biomass dynamics associated with deforestation, fire and conversion to cattle pasture in a Mexican tropical dry forest. Forest Ecology and Management, 176,1-12.

Keating P.L. (1998). Effects of anthropogenic disturbances on páramo vegetation in Podocarpus National Park, Ecuador. Physical Geography. 1998; 19: 221-238. 
Knowlton J.L., \& Graham C.H. (2011). Species interactions are disrupted by habitat degradation in the highly threatened Tumbesian region of Ecuador. Ecological Applications, 21, 2974-2986.

Kouki J., Löfman S., Martikainen P., Rouvinen S., \& Uotila A (2001). Forest fragmentation in Fennoscandia: linking habitat requirements of wood-associated threatened species to landscape and habitat changes. Scandinavian Journal of Forest Research, 16, 27-37.

Lambin E., Geist H., \& Lepers E. (2003). Dynamics of land-use and land cover changes in Tropical regions. Annual Review of Environment \& Resources, 28, 205-241.

Landis J.R., \& Koch G.G. (1977). The measurement of observer agreement for categorical data. Biometrics, 33, 159-174.

Laurance W.F., Goosem M., \& Laurance S.G. (2009). Impacts of roads and linear clearings on tropical forests. Trends in Ecology \& Evolution, 24, 659-669.

López S., Sierra R., \& Tirado M. (2010). Tropical deforestation in the Ecuadorian Chocó: Logging practices and socio-spatial relationships. The Geographical Bulletin, 51, 3-22.

Lu D., Mausel P., Brondizio E., \& Moran E. (2004). Change detection techniques. International Journal of Remote Sensing, 25, 2365-2401.

Macedo M.N., DeFries R.S., Morton D.C., Stickler C.M., Galford G., \& Shimabukuro, Y. (2012). Decoupling of deforestation and soy production in the southern Amazon during the late 2000s. Proceedings of the National Academy of Sciences, 109, 1341-1346.

Macleod R.D., \& Congalton R.G. (1998). A quantitative comparison of change-detection algorithms for monitoring eelgrass from remotely sensed data. Photogrammetric Engineering \& Remote Sensing, 64, 207-216.

Maldonado N. (2002). Clima y vegetación de la Región Sur del Ecuador. In: Aguirre Z, Madsen J.E., Cotton E., Balslev, editores. Botánica Austroecuatoriana. Ediciones Abya Ayala, pp. 1-28. Quito. 
Marquette C.M. (1998). Land use patterns among small farmer settlers in the northeastern Ecuadorian Amazon. Human Ecology, 26, 573-598.

McGarigal K., Cushman S.A., Neel M.C., \& Ene E. (2002). FRAGSTATS v3: Spatial pattern analysis program for categorical maps computer software program produced by the authors at the University of Massachusetts, Amherst, Available at: http://wwwumassedu/landeco/research/fragstats/fragstatshtml

Mena C. (2008). Trajectories of land-use and land-cover in the northern Ecuadorian Amazon: temporal composition, spatial configuration and probability of change. Photogrammetric Engineering \& Remote Sensing, 6, 737-751.

Mendoza S.J., \& Etter R.A. (2002). Multitemporal analysis (1940-1996) of land cover changes in the southwestern Bogota highplain (Colombia). Landscape \& Urban Planning, 59, 147-158.

Millette T.H., Tuladhar A.R., Kasperson R.E., \& Turner II B.L. (1995). The use and limits of remote sensing for analyzing environmental and social change in the Himalayan middle mountains of Nepal. Global Environmental Change, 5,367-380.

Ministerio del Ambiente del Ecuador. (2012). Sistema de Clasificación de los Ecosistemas del Ecuador Continental. Subsecretaria de Patrimonio Natural. pp. 136. Quito.

Ministerio del Ambiente del Ecuador (2010). Reservas de Biosfera del Ecuador: lugares excepcionales. Quito.

Nöske N., Hilt N., Werner F.A., Brehm G., Fiedler K., Sipman H.J., et al. (2008). Disturbance effects on diversity of epiphytes and moths in a montane forest in Ecuador. Basic \& Applied Ecology, 9, 4-12.

Pala V., \& Pons X. (1995). Incorporation of relief in polynomial-based geometric corrections. Photogrammetric Engineering \& Remote Sensing, 61, 935-944. 
Pan W.K., Walsh S.J., Bilsborrow R.E., Frizzelle B.G., Erlien C.M., \& Baquero F. Farmlevel models of spatial patterns of land use and land cover dynamics in the Ecuadorian Amazon agriculture. Ecosystems \& Environment, 101, 117-134.

Peters T., Drobnik T., Meyer H., Rankl M., Ritcher M., Rollenbeck R., et al. (2013). Environmental changes affecting the Andes of Ecuador In: Bendix J., Beck E., Braüning A., Makeschin F., Mosandl R., Scheu S., et al., editors. Ecosystem Services, Biodiversity and Environmental Change in a Tropical Mountain Ecosystem of South Ecuador. Springer, pp. 20-34. Berlin.

Portillo-Quintero C.A., \& Sánchez-Azofeifa G.A. (2010). Extent and conservation of tropical dry forests in the Americas. Biological Conservation, 143, 144-155.

Puyravaud J.P. (2003). Standardizing the calculation of the annual rate of deforestation forest. Ecology \& Management, 177, 593-596.

Riaño D., Chuvieco E., Salas J., \& Aguado I. (2003). Assessment of different topographic corrections in Landsat-TM data for mapping vegetation types. Geoscience and Remote Sensing, 41, 1056-1061.

Richter M. (2003). Using epiphytes and soil temperatures for eco-climatic interpretations in Southern Ecuador. Erdkunde, 57, 161-181.

Rodriguez-Mahecha J.V., Salaman P., Jorgensen P., Consiglio T., Suárez L., Arjona F., et al. "Tumbes - Chocó - Magdalena". In: Mittermeier R., Robles P., Hoffmann M., Pilgrim J., Brooks T., Goettsch C., et al. Hotspots Revisted: Earth's biologically richest and most endangered terrestrial ecoregions. CEMEX, Mexico DF.

Rudel T.K., Bates D., \& Machinguiashi R. (2002). A tropical forest transition? Agricultural change, out-migration, and secondary forests in the Ecuadorian Amazon. Annals of the Association of American Geographers, 92, 87-102.

Santos B.A., Peres C.A., Oliveira M.A., Grillo A., Alves-Costa C.P., 6 Tabarelli M. (2008). Drastic erosion in functional attributes of tree assemblages in Atlantic forest fragments of northeastern Brazil. Biology Conservatio, 14, 249-260. 
Saunders D.A., Hobbs R.J., \& Margules, C.R. (1991). Biological consequences of ecosystem fragmentation: a review. Conservation Biology, 5, 18-32.

Schowengerdt R.A. (2007). Remote Sensing: Models and Methods for Image Processing. 3rd ed. United States of America: Academic Press.

Schulz, J.J., Cayuela L., Echeverria C., Salas J., \& Rey Benayas J.M. (2010). Monitoring land cover change of the dryland forest landscape of Central Chile (1975-2008). Applied Geography, 30, 436-447.

Sierra R., Campos F., \& Chamberlin J. (2002). Assessing biodiversity conservation priorities: ecosystem risk and representativeness in continental Ecuador. Landscape \& Urban Planning, 59, 95-110.

Sierra R., \& Stallings J. (1998). The dynamics and social organization of tropical deforestation in Northwest Ecuador, 1983-1995. Human Ecology, 26, 135-161.

Sierra R. (2000). Dynamics and patterns of deforestation in the western Amazon: the Napo deforestation front, 1986-1996. Applied Geography, 20,1-16.

Sierra R. (1999). Vegetación Remanente del Ecuador Continental Scale: 1:1,000,000 Proyecto 426 INEFAN/GEF-BIRF, Wildlife Conservation Society \& EcoCiencia. Quito.

Skole D., \& Tucker C. (1993). tropical deforestation and habitat fragmentation in the Amazon: Satellite Data from 1978 to 1988. Science, 260, 1905 -1910.

Southgate D., \& Runge C.F. (1990). The institutional origins of deforestation in Latin America. University of Minnesota, Department of Agriculture and Applied Economics Staff paper no P90-5 St Paul, MN: University of Minnesota.

Tabarelli M., Aguiar A., Girao L.C., Peres C.A., \& Lopes A.V. (2010). Effects of pioneer tree species hyperabundance on forest fragments in Northeastern Brazil. Conservation Biology, 24, 1654-1663. 
Tabarelli M., Peres C.A., \& Melo F.P. (2012). The 'few winners and many losers' paradigm revisited: emerging prospects for tropical forest biodiversity. Biological Conservation, 155, 136-140.

Tapia-Armijos M.F., González J., Valdivieso M., Bravo F., \& Espinosa C.I. (2011). Cobertura Vegetal y Uso Actual del Suelo de la Provincia de Zamora Chinchipe. Informe Técnico. Universidad Técnica Particular de Loja. Loja.

Thies B., Meyer H., Nauss T., \& Bendix J. (2012). Projecting land-use and land-cover changes in tropical mountain forest of Southern Ecuador. Journal of Land Use Science, 9, 1-33.

Torracchi E., Tapia M.F., Escudero A., \& De la Cruz M. (2012). Deforestación en una región montañosa megadiversa en los Andes: dinámica del paisaje en el Sur del Ecuador. In: Maestre F., De la Cruz M., editores. Avances en el Análisis Espacial de Datos Ecológicos: Aspectos Metodológicos y Aplicados. ECESPA-Asociación de Española de Ecología Terrestre, pp. 275-289. Móstoles.

Toutin T. (2004). Geometric processing of remote sensing images: models, algorithms and methods. International Journal of Remote Sensing, 25, 1893-1924.

Trejo I., \& Dirzo R. (2000). Deforestation of seasonally dry tropical forest: a national and local analysis in Mexico. Biological Conservation,94, 133-142.

Valencia R., Pitman N., \& León-Yánez S. (2000). Libro rojo de las plantas endémicas del Ecuador. Pontificia Universidad Católica del Ecuador. Quito.

Viña A., Echavarria F.R., \& Rundquist D.C. (2004). Satellite change detection analysis of deforestation rates and patterns along the Colombia-Ecuador border. AMBIO, 33, 118125.

Vitousek P.M. (1994). Beyond global warming: ecology and global change. Ecology, 75, 1861-1876. 
Weigend M. (2004). Additional observations on the biogeography of the Amotapehuancabamba zone in northern Peru: Definig the South-Eastern limits. Revista Peruana de Biología, 11, 127-134.

Weigend M. (2002). Observations on the biogeography of the Amotape-Huancabamba zone in Northern Peru. The Botanical Review; 68(1), 38-54.

Werner F.A., Homeier J., \& Gradstein S.R. (2005). Diversity of vascular epiphytes on isolated remnant trees in the montane forest belt of southern Ecuador. Ecotropica, 11, 21-40.

Wolf K., Veldkamp E., Homeier J., \& Martinson G.O. (2011). Nitrogen availability links forest productivity, soil nitrous oxide and nitric oxide fluxes of a tropical montane forest in southern Ecuador. Global Biogeochemical Cycles, 25 (4).

Wunder S. (2000). The economics of deforestation: the example of Ecuador. Hounmills: Macmillan.

Young A., Boyle T., \& Brown T. (1996). The population genetic consequences of habitat fragmentation for plants. Trends in Ecology \& Evolution, 11, 413-418.

Young A.G., \& Clarke G.M. (2000). Genetics, demography and viability of fragmented populations. Cambridge University Press. 


\subsection{Supporting information}
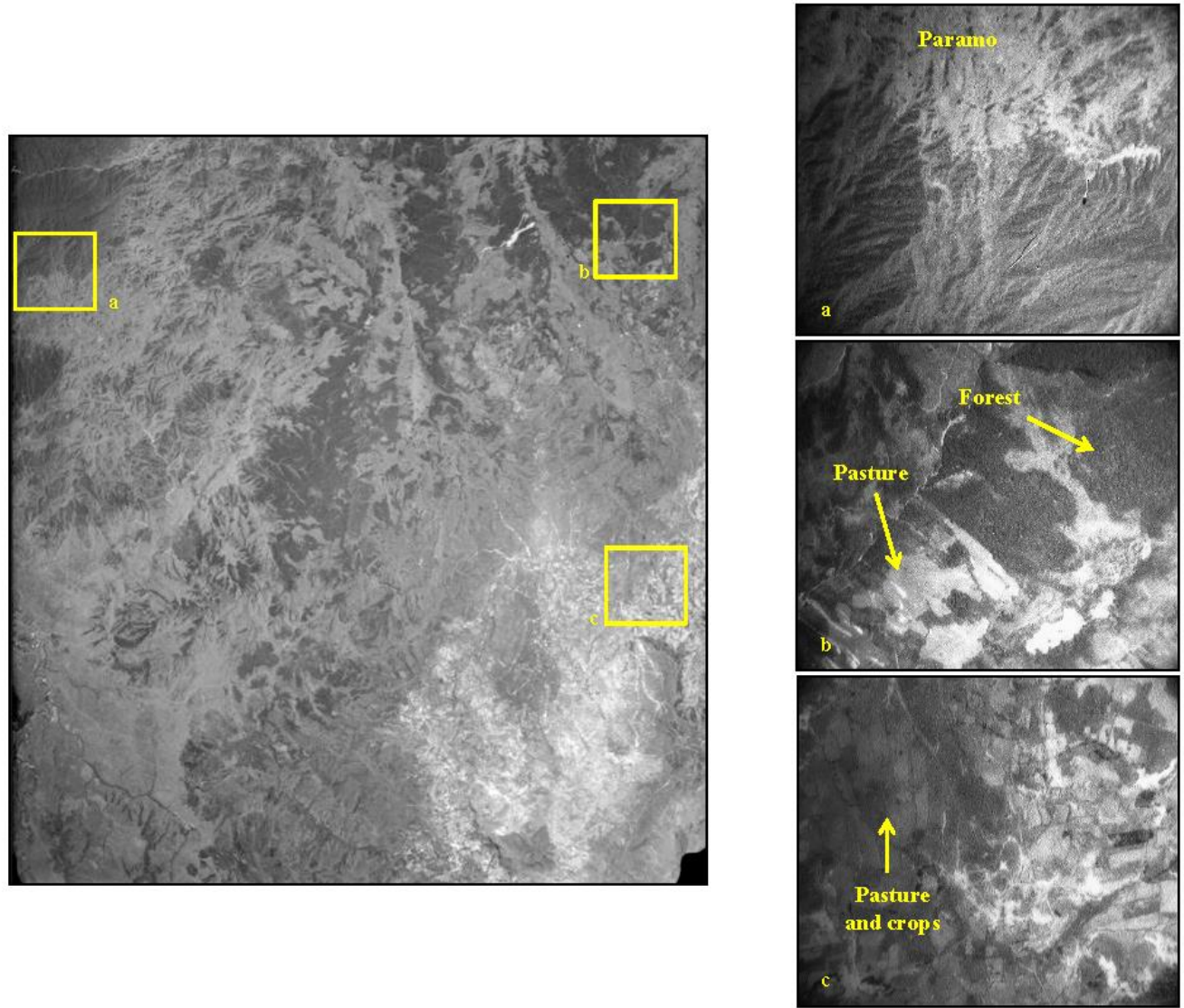

Figure S1 Aerial photograph (1976) that shows landscape mosaic of Saraguro in South Ecuador. A) Paramo (lighter tone) of Saraguro - Yacuambi wetland system dominated by herbaceous species limiting with forest (darker tone); B) Mosaic of pastures (lighter tone) and forest (darker tone), C) Agricultural zone around the town of Saraguro where a mosaic with high patchiness could be observed. 

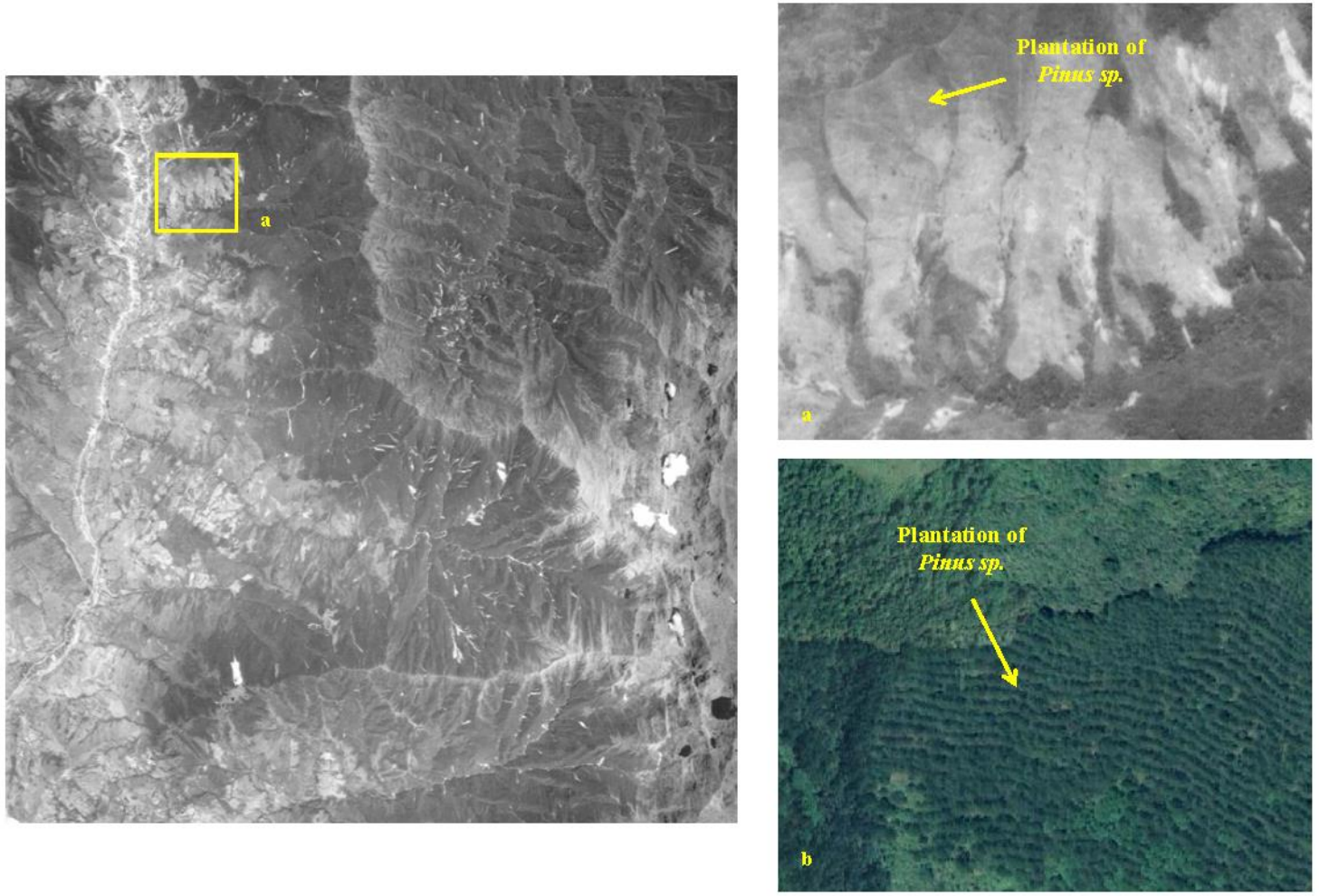

Figure S2 Aerial photographs of Loja - Vilcabamba road. A) Aerial photographs (1976) close to Loja in the Cajanuma sector that shows a younger plantation of Pinus patula, the grey tones of plantation areas, pastures and forests are different, B) Aerial photograph (2008) of the same plantation in the Cajanuma sector that shows the linear patterns that characterizes this cover. The aerial photograph in section $b$ ) was obtained and provided by the Ecuadorian Project SIGTIERRAS (Ministerio de Agricultura, Ganadería, Acuacultura y Pesca; Proyecto Sistema Nacional de Información y Gestión de Tierras Rurales e Infraestructura Tecnológica). 

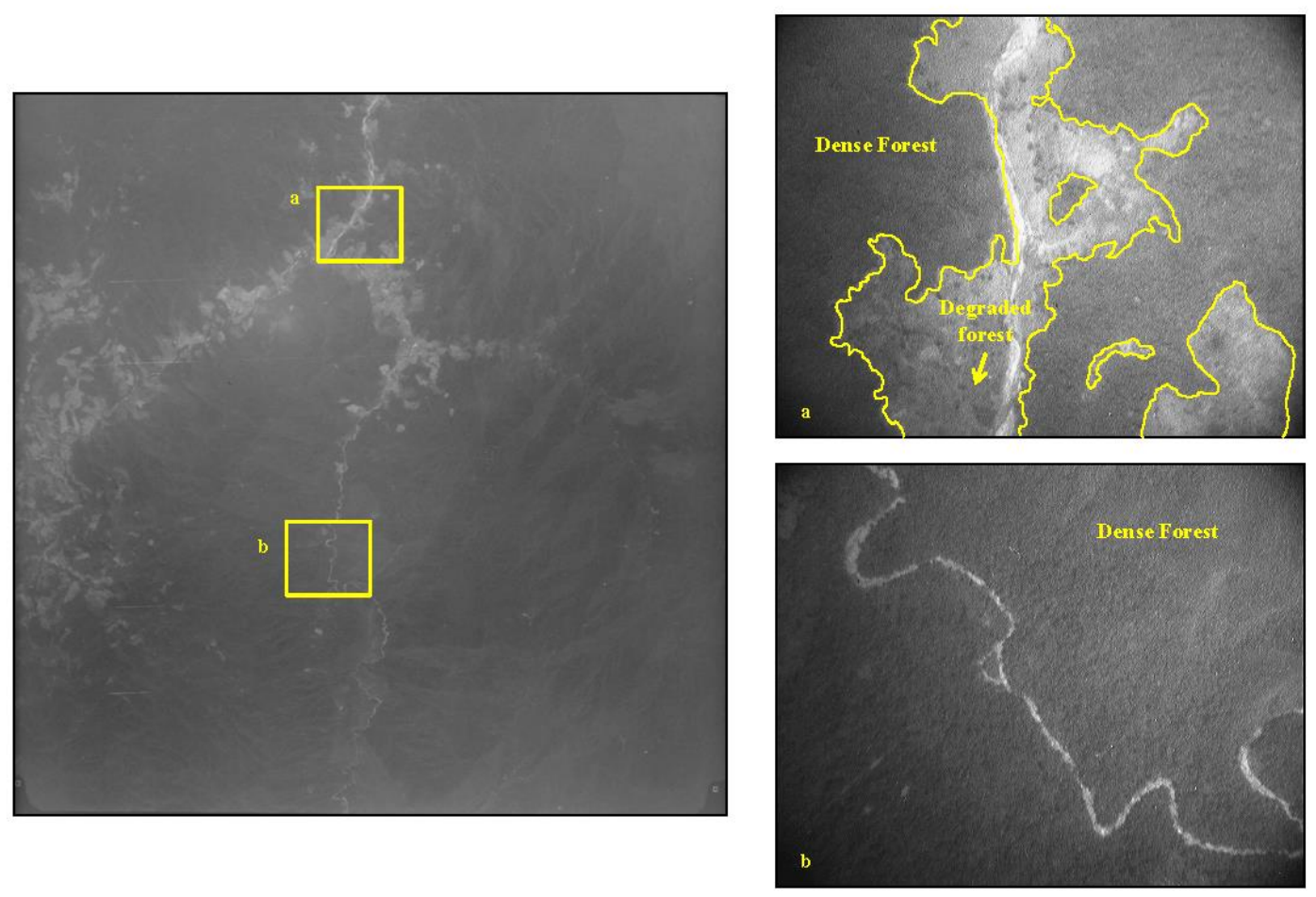

Figure S3 Aerial photograph (1989) of Rio Zamora basin. A) Dense forest (darker tone) with gaps that show human intervention (lighter tone), the yellow polygons delimit the dense forest area that was classified as natural cover. B) Continuous surface of dense forest. 


\section{CHAPTER 3}

\section{Spatio-temporal analysis of the human}

footprint in South Ecuador: influence of

human pressure on ecosystems and effectiveness of protected areas

\section{María Fernanda Tapia-Armijos ${ }^{1,2}$, Jürgen Homeier ${ }^{2}$, David Draper Munt ${ }^{1,3}$}

${ }^{1}$ Sección de Ecología y Sistemática, Departamento de Ciencias Naturales, Universidad Técnica Particular de Loja, Loja, Ecuador,

2 Plant Ecology, Albrecht von Haller Institute for Plant Sciences, University of Göttingen, Göttingen, Germany,

${ }^{3}$ Centro de Ecologia, Evolução e Alterações Ambientais (CE3C - Centre for Ecology, Evolution and Environmental Changes), C2, Campo Grande, 1749-016, Portugal. 


\section{Spatio-temporal analysis of the human footprint in South Ecuador: influence of human pressure on ecosystems and effectiveness of protected areas}

\subsection{Abstract}

Human influence and its impacts are perceptible in all ecosystems resulting in land transformation, changes in global biogeochemistry, climate change, and loss of biological diversity. Mapping the spatial and temporal patterns of human influence is essential to address land use management and conservation programs. In this study, we tailored the Human Footprint index (HF) developed at global level to evaluate the spatial and temporal patterns of human pressure in South Ecuador for 1982, 1990 and 2008. Landscape and ecosystem levels were analyzed to identify the contribution of different human proxies to the HF. We also used the HF to evaluate the effectiveness of protected areas to reduce human pressure in the surrounding landscape. We found that levels of human pressure increased and the wildest areas decreased since 1982. We identified important "hotspots of changes" in the seasonally dry forests in the western part and the premontane evergreen forest in the eastern part of the study area. Our results show that each human proxy contributes in a different way to the observed values of HF in the studied ecosystems. Finally, we found that Podocarpus NP, the most important protected area in our study region, seems to be partially effective in reducing human pressure inside and in the buffer zones where only a low increase in HF was detected. However, the HF values observed in the surrounding landscape were higher than those observed in the buffer zone and inside the

protected area. We demonstrated that HF could be a useful regional evaluation tool to facilitate conservation planning. 


\subsection{Introduction}

Human influence and its impacts are perceptible in all terrestrial and marine ecosystems (Halpern et al., 2008; Sanderson et al., 2002) resulting in land transformation, changes in global biogeochemistry, climate change, and loss of wilderness areas and biological diversity (Vitousek, 1994; Watson et al., 2016). Human pressure is caused by the synergistic interaction of demographic, politic, physic, and socioeconomic factors. For instance, a higher demand of resources is related to population growth and also to the affluence levels (Dietz, et al., 2007; Goudie, 2013; McKee, 2004; Weinzettel et al., 2013; York et al., 2003). Land transformation is strongly associated with trade dynamics at national and international levels and with land disparities (Venter et al., 2016). Mapping the spatial and temporal patterns of human pressure is essential to address land use management and conservation programs (Woolmer et al., 2008).

The Human Footprint index (HF) proposed by Sanderson et al. (2002) is a tool that maps the spatial dimension of human influence showing the extent and intensity of human presence and its actions. The HF shows not only the levels of anthropogenic stress that an area is exposed to but also the wildest, still untouched, zones which could be included under protection. According to Haines et al. (2008) the HF is also a good approach to assessing the success of landscape conservation efforts (e.g. if anthropogenic influence was mitigated or reduced after the implementation of a conservation strategy, the strategy could be considered as successful). The temporal analysis of the HF also allows the understanding of changing human influence and the identification of "hotspots of change" as well as the description of the human proxies which contribute most to the observed values of HF (Woolmer et al., 2008). The level of disturbances present in buffer zones is also directly related to the effectiveness of protected areas (DeFries et al., 2005).

The dynamic nature of human threats makes it essential for conservation planners to consider the spatially explicit changes in threats and the fact that threats (e.g. increase in human population) do not have a uniform behavior across the landscape (Pressey et al., 2007). Ellis and Ramankutty (2008) demonstrated that human proxies exhibit particular patterns in different ecosystems and therefore contribute differently to human impact levels. 
In this context, the HF can help us understand these differences, especially in areas with a high heterogeneity of biophysical, climatic, socio-economic, and cultural factors as tropical landscapes (Tosi and Voertman, 1964).

The HF needs to be interpreted carefully when it is applied to understand local patterns. Woolmer et al. (2008) rescaled the HF at an ecoregional level and concluded that although at global and ecoregional level the same general patterns of human influence were observed, the ecoregional analysis revealed a higher level of spatial heterogeneity, supporting the importance of local studies.

The objective of this study is to demonstrate how geospatial tools developed at local scale could be used to provide information about the level of human pressure that an area is exposed to and how this information can be used for land managers and decision makers to prioritize areas taking into account the local realities. Specifically, this study aims to tailor the HF proposed by Sanderson et al. (2002) to South Ecuador, an area with substantial and unique biodiversity and endemism, in order 1) to evaluate the spatial changes in the HF values for two different periods (1982- 1990 and 1990-2008), and to localize the principal "hotspots of change" and the wildest areas, 2) to understand how human pressure levels vary between different ecosystems, 3 ) to define which is the contribution of the analyzed human proxies to the $\mathrm{HF}$ and 4) to evaluate the effectiveness of the most important protected area in reducing human pressure.

\subsection{Methods}

\subsubsection{Study area}

The target area covers the provinces of Loja and Zamora Chinchipe in South Ecuador that cover a total area of $21631 \mathrm{~km}^{2}$ (Figure 3.1). In this region elevation ranges from 105 to $3866 \mathrm{~m}$ a.s.l. (Farr et al., 2007). The mean annual temperature ranges from $7{ }^{\circ} \mathrm{C}$ to $25^{\circ} \mathrm{C}$, and the precipitation ranges from $500 \mathrm{~mm}$ to $8000 \mathrm{~mm}$ annuals (Bendix and Lauer, 1992; Emck, 2007). Soil conditions are highly variable, depending on elevation, bedrock, slope position and climate (e.g. Wolf et al., 2011). 
South Ecuador is characterized by five principal vegetation types (more details are provided in Tapia-Armijos et al., 2015). The montane evergreen forest (MEF) (occupies $45 \%$ of the surface area) and the premontane evergreen forest (PMEF; 23\%), both are located mainly on the eastern and more humid escarpment of the Andes. The páramo (Pa) occupies only $4 \%$ of the surface and is present at lower altitudes than in the rest of the country. The shrubland $(\mathrm{Sl} ; 17 \%)$ and the seasonally dry forest (SDF; 23\%) are more characteristic of the western escarpment of the Andes under more arid conditions.

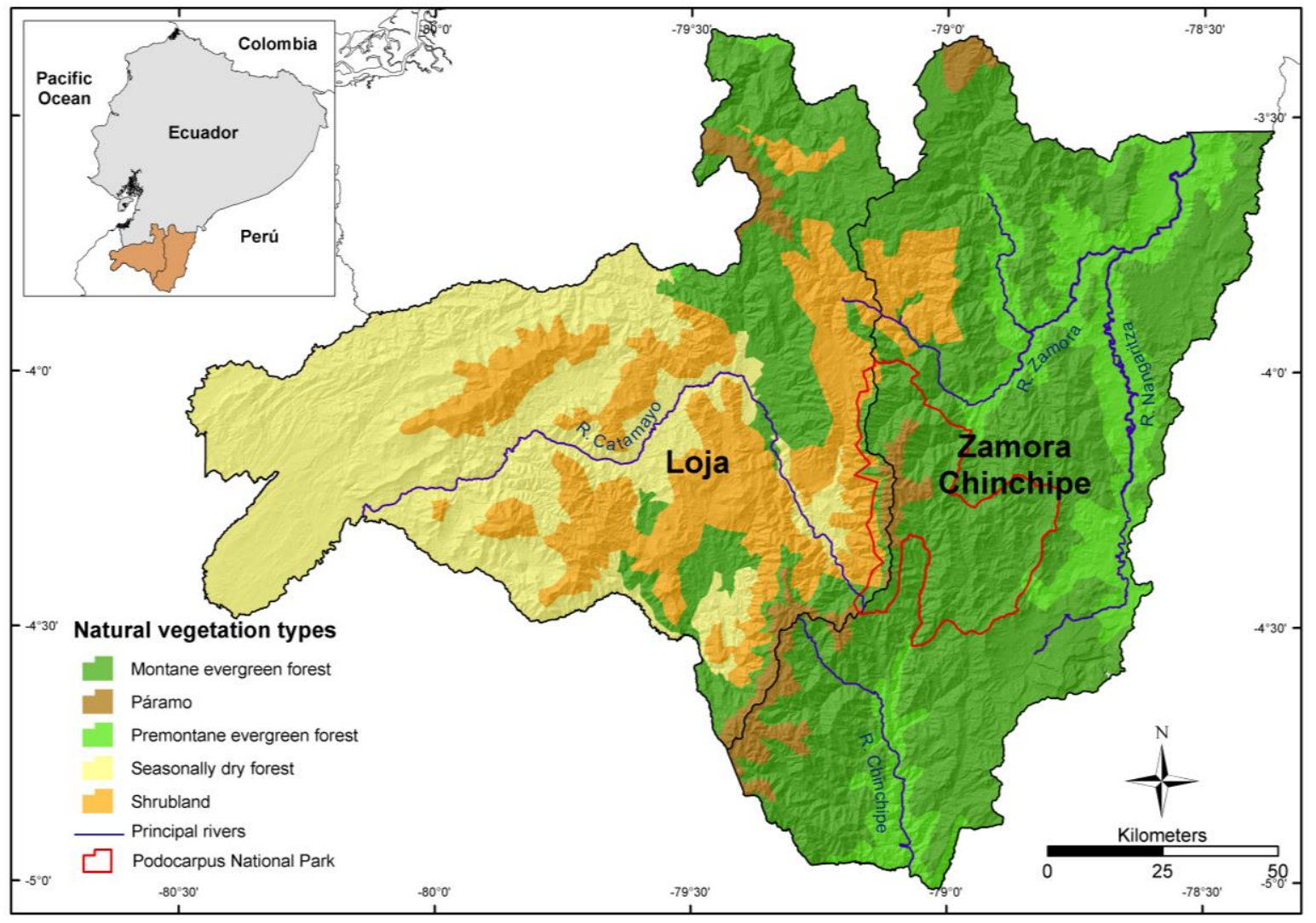

Figure 3.1 Location of the study area and distribution of the principal vegetation types in the southernmost Ecuadorian provinces of Loja and Zamora Chinchipe.

The high heterogeneity of landscape and climate and the location of South Ecuador in the Amotape - Huancabamba Andean depression are reasons for the observed high levels of biodiversity and endemism in the area and for this South Ecuador has been recognized as an important center of floristic diversity (Homeier et al., 2010; Richter et al., 2009; Weigend, 2002). Nevertheless, the area is highly threatened as consequence of human 
actions, Tapia-Armijos et al. (2015) registered an increase of fragmentation with an annual deforestation rate of $2.01 \%$ for the last three decades (1976-2008), where the largest surface of native forest was principally degraded or converted to pastures.

\subsubsection{Human footprint map}

Human Footprints maps were obtained for years 1982, 1990 and 2008. This temporal series was defined according to the availability and quality of geographical data (Table 3.1). To map the human pressure levels for South Ecuador we rescaled and adapted the Human Footprint (HF) method proposed by Sanderson et al. (2002) who combined human population density, land transformation, power infrastructure distribution and human access as proxies to evaluate the spatial distribution of human pressure.

These four variables were derived from the combination of the data described in Table 3.1, some of this data had to be preprocessed and rescaled to considering the geographical characteristics of the studied area as well as the available geographic data (for more details see Appendix). The four variables were expressed as overlaying grids at a resolution of $100 \times 100$ meters and coded with scores from 0 to 10 according to their contribution ( 0 for low human influence to 10 for high human influence). The sum of the four variables resulted in the Human Influence Index (HII) for each year.

The human influence interacts in different ways depending on the ecological attributes of the landscape and its response to transformation (Sanderson et al., 2002). Accordingly, we normalized the HII for each year by using the main vegetation types described for South Ecuador (Figure 3.1, see details in Tapia-Armijos et al. 2015) to obtain a more detailed explanation of the spatial variation of human pressure. In this way, we assigned a score of 0 to the grid cell with the minimum HII value and a score of 100 to the cell with the maximum value in each vegetation type, stretching intermediate values linearly between these extremes. The result of this normalization was the Human Footprint (HF), calculated for each study year (1982, 1990 and 2008) separately. 
Table 3.1 Geographical datasets used to map Human Footprint in South Ecuador.

\begin{tabular}{|c|c|c|c|c|c|}
\hline Dataset types & Dataset names & Dataset format & Year & Source & Reference \\
\hline $\begin{array}{l}\text { Population } \\
\text { density }\end{array}$ & National population census & Numeric & $\begin{array}{l}1982 \\
1990 \\
2010\end{array}$ & $\begin{array}{l}\text { Instituto Nacional de } \\
\text { Estadísticas y Censos } \\
\text { (INEC) }\end{array}$ & INEC 1982, 1990, 2010 \\
\hline \multirow{5}{*}{$\begin{array}{l}\text { Land } \\
\text { transformation }\end{array}$} & $\begin{array}{l}\text { Vegetal cover maps for continental } \\
\text { Ecuador }\end{array}$ & Vectorial & 1982,1990 & $\begin{array}{l}\text { Sistema Nacional de } \\
\text { Información (SNI) }\end{array}$ & MAGAP 1982, 1990 \\
\hline & $\begin{array}{l}\text { Land cover and land use of Loja and } \\
\text { Zamora Chinchipe provinces }\end{array}$ & Vectorial & 2008 & NCI / UTPL & $\begin{array}{l}\text { Cueva et al. 2010, Tapia- } \\
\text { Armijos et al. } 2011\end{array}$ \\
\hline & Population centers & Vectorial & 2011 & $\begin{array}{l}\text { Instituto Geográfico } \\
\text { Nacional }\end{array}$ & IGM 2011 \\
\hline & Map of cities & Vectorial & 2011 & $\begin{array}{l}\text { Instituto Geográfico } \\
\text { Nacional }\end{array}$ & IGM 2011 \\
\hline & Map of roads & Vectorial & $\begin{array}{l}1969 \\
2000 \\
2011\end{array}$ & $\begin{array}{l}\text { Sistema Nacional de } \\
\text { Información (SNI) and } \\
\text { Peters et al. } 2013\end{array}$ & $\begin{array}{l}\text { IGM 2011, } 1969 \text { network } \\
\text { based on Peters et al. } 2013\end{array}$ \\
\hline \multirow{3}{*}{ Human access } & Maps of roads & Vectorial & $\begin{array}{c}1969 \\
2000 \\
2011\end{array}$ & $\begin{array}{l}\text { Sistema Nacional de } \\
\text { Información (SNI) and } \\
\text { Peters et al. } 2013\end{array}$ & $\begin{array}{l}\text { MAGAP 2003, } 1969 \\
\text { network based on Peters et } \\
\text { al. } 2013\end{array}$ \\
\hline & Rivers & Vectorial & & & IGM 2011 \\
\hline & Digital elevation model (DEM) & Raster & $\begin{array}{l}\text { Accessed } \\
\text { in } 2013\end{array}$ & $\begin{array}{l}\text { Shuttle Radar Topographic } \\
\text { Mission (SRTM) }\end{array}$ & Farr 2007 \\
\hline $\begin{array}{l}\text { Electrical } \\
\text { power } \\
\text { infrastructure }\end{array}$ & $\begin{array}{l}\text { Defense meteorological satellite program, } \\
\text { Stable lights }\end{array}$ & Raster & $\begin{array}{l}1992 \\
2008\end{array}$ & NOAA / NGDC & Elvidge et al. 1997 \\
\hline Normalization & South Ecuador natural vegetation types & Vectorial & 2008 & Tapia-Armijos et al. 2015 & $\begin{array}{l}\text { Balslev and Øllgaard 2002, } \\
\text { Homeier et al. } 2008 \text { and } \\
\text { Sierra } 1999 .\end{array}$ \\
\hline
\end{tabular}




\subsubsection{Human footprint change analysis}

We evaluated how HF and thereby human pressure changed temporally and spatially from 1982 to 2008 identifying a human influence gradient from the wildest areas to the most influenced areas. For this, we reclassified the HF values (0-100) in 4 classes: Wildest areas $(\mathrm{HF}=0)$, low impacted areas (HF: 1-15), medium impacted areas (HF: $16-60)$ and high impacted areas (HF: $61-100)$. This evaluation was done at the regional level but also for each of the different vegetation types.

To locate areas considered as "hotspots of change", we calculated a single mean change rate (Equation. 1) for each pixel, where $\Delta y / \Delta x$ is the mean change rate of $\mathrm{HF}$ and $f(x 2)$ and $f(x 1)$ are the HF values in the second (x2) and first (x1) study year, respectively. The change analysis allowed us to detect the pixels where the changes of HF were stronger.

$$
\Delta y / \Delta x=f(x 2)-f(x 1) / x 2-x 1
$$

The resulting change maps were reclassified, those pixels with negative mean variation rates $(\Delta y / \Delta x<0)$, indicating a decrease of HF values between the last and first year, where included within the category "Decreased". The pixels where the HF values were the same in the two years $(\Delta y / \Delta x=0)$ were included within the category "No change". The pixels showing an increase in the HF values were classified according to the intensity of the increase into three categories, i.e. $0<\Delta y / \Delta x \leq 1$ for "Low increase", $1<\Delta y / \Delta x \leq 2$ for "Moderate increase" and $\Delta y / \Delta x>2$ for "High increase". Finally, we considered as "hotspots of change" those areas included within the category "High increase" where the HF increased from 1982 to 2008 by 30 or more units.

\subsubsection{Importance of human footprint inputs}

To understand the influence of human proxies in the observed patterns of HF along the different natural vegetation types we analyzed the relation between HF scores and the HI values of the input layers. For every natural system, we generated a stack of five layers (one for each human proxy and one for the HF of each corresponding area). Then we took a random sample of the $1 \%$ of the total number of pixels (the study area had a total of 
4390210 pixels) of each vegetation type and extracted for the selected pixels the values from the stack. A linear regression analysis was used to evaluate the relation between the response variable (HF) and the four predictor variables (human population density, land transformation, human access and power infrastructure).

\subsubsection{Effectiveness of protected areas}

Eleven percent of the total surface of the study area are under the highest level of governmental protection called "Patrimonio de Areas Naturales del Estado" (PANE), but only one of the five protected areas that belong to the PANE is sufficiently old to be used in this analysis. The Podocarpus National Park (PNP, Figure 3.2), with a total surface of 1450 $\mathrm{km}^{2}$ has been established in 1982 which coincide with our first period of analysis. To evaluate the effectiveness of PNP we used the methodology proposed by Ewers and Rodrigues (2008) which mentioned that the effectiveness of a protected area is not only given by the stabilization or reduction of human pressure inside the protected area but also if the human pressure is displaced to the adjacent territory, a phenomenon known as "leakage". To prove this for each study year, we selected a sample area that includes the PNP and its adjacent territory (Figure 3.2). In this sample we: 1) divided the PNP area into three concentric bands of equal area $\left.\left(483 \mathrm{~km}^{2}\right), 2\right)$ created three similar sized concentric areas outside the PNP and 3) selected from the broader landscape six circular random parcels with equal area $\left(483 \mathrm{~km}^{2}\right)$ to the concentric bands, the control zones were randomly selected using the random points tool in ArcGis 9.3. For the twelve areas (for each study year) we extracted the values of $\mathrm{HF}$ and calculated its average. The average value obtained from the random landscape parcels was used as a baseline to compare it with the average values obtained from the concentric bands inside and outside the PNP. According to Ewers and Rodrigues (2008), the reserve has a positive effect if $\mathrm{HF}$ values inside the reserve are smaller than baseline values of the control parcels. If HF values in the buffer zone around the reserve have increased "leakage" is indicated. The reserve is effectively reducing the human pressure across the landscape if the difference between the HF values inside the reserve and the baseline is greater than the difference between the HF values in the buffer zone and the baseline. 


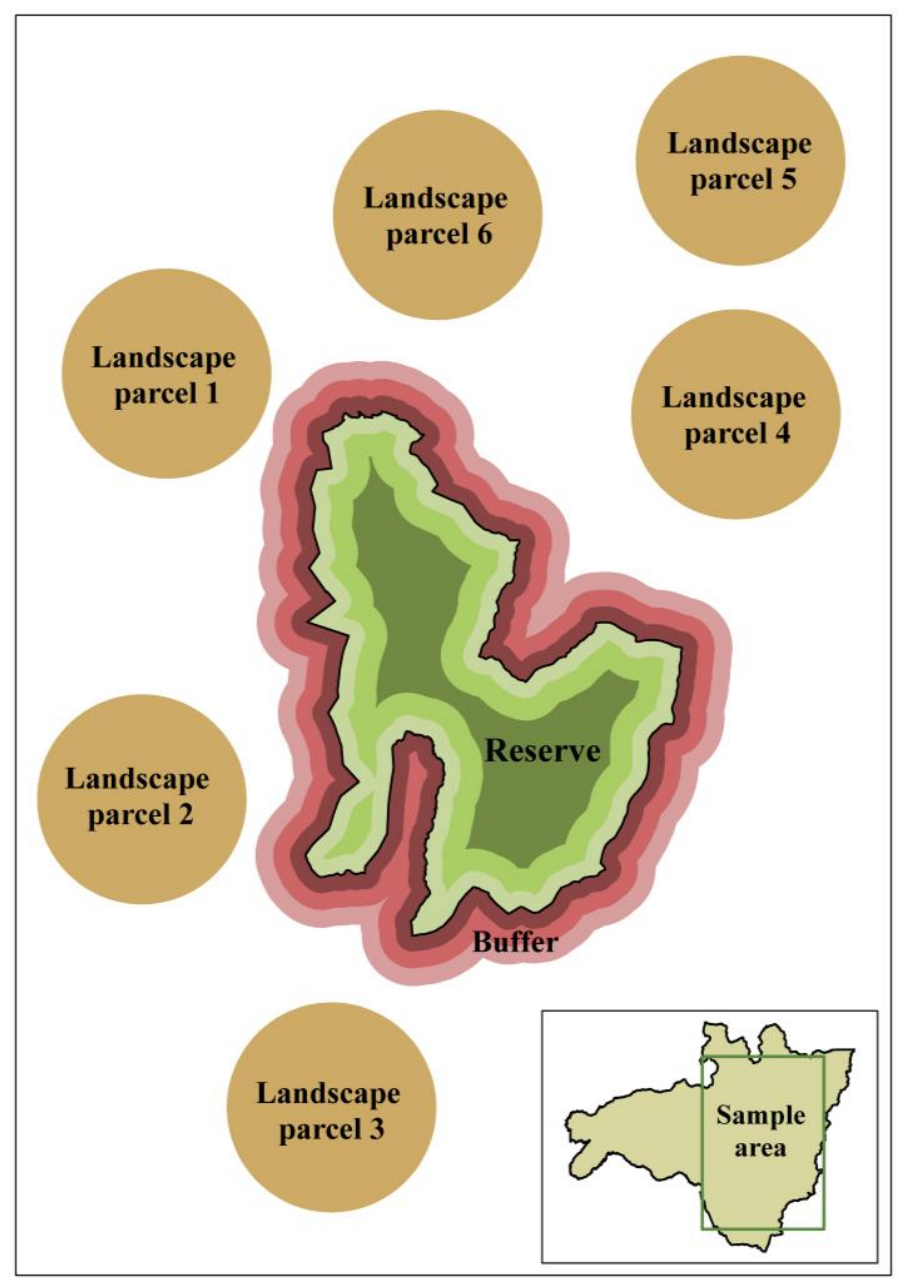

Figure 3.2 The conceptual model to evaluate the effectiveness of the Podocarpus National Park in South Ecuador. In green tones the concentric zones inside the $\mathrm{PNP}$, in red tones the concentric zones outside the PNP and in brown tone the random control parcels in the surrounding landscape.

\subsection{Results}

\subsubsection{Spatial and temporal changes of Human Footprint}

The general analysis of the HF for 1982, 1990 and 2008 (Figure 3.3) shows an increase of human pressure all over the study area which is more noticeable in the eastern part. While in 1982 this part maintained large areas that could be considered as wildest areas, the 
western part exhibited large areas of high and intermediate levels of human pressure, which principally radiate from major urban and rural areas. Intact areas were already very few and small in the western study area. In 1990 some of the wildest areas in the eastern part had disappeared, especially those located on the eastern slopes of the Andean range. In the western part, there was an increase in the levels of human pressure although the patterns were similar to 1982 . In 2008, the region was characterized by large areas with HF values above 50 and a more fragmented pattern that shows smaller wildest areas patches dispersed in a matrix of human transformation.
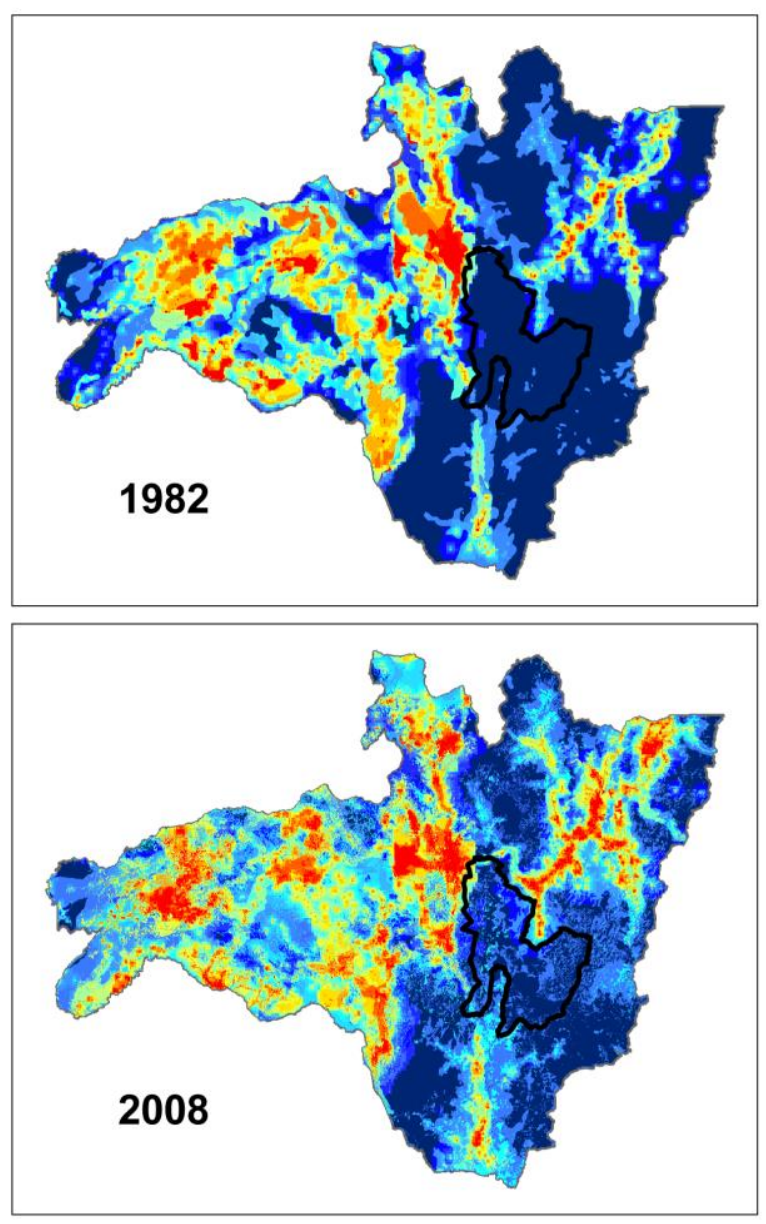

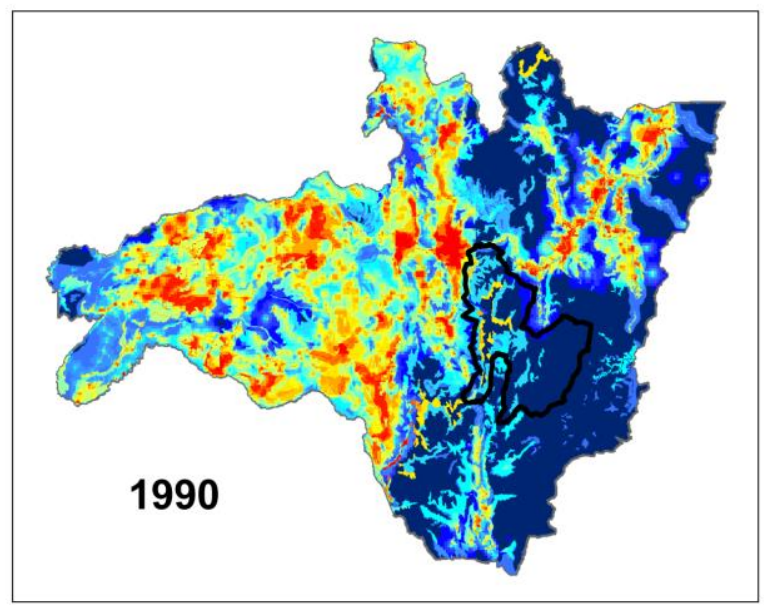

\section{Legend}
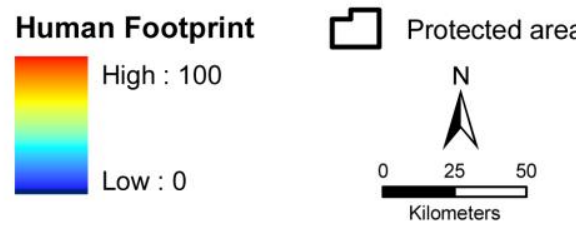

Figure 3.3 The maps display the spatial and temporal change of patterns of human pressure in South Ecuador for the three study years. 
The multitemporal analysis allowed us to observe how two of the principal river systems of the region (the Rio Zamora basin in the northeastern part and the Río Chinchipe in the southeastern part of the study area) supported the expansion of human pressure levels.

In 1982 the landscape of South Ecuador was mainly occupied by wildest areas (36\%) and moderately impacted areas (37\%), but in 1990 and 2008 the landscape was dominated by areas with moderate impact (51\% and $49 \%$ respectively) with $\mathrm{HF}$ values up to 60 . The wildest areas decreased progressively since 1982, and for 2008 only $21 \%$ of the landscape was not affected by human pressure. In addition, a small increase of the highly impacted areas was noticed (from $1 \%$ to $5 \%$ ) (Figure 3.4).

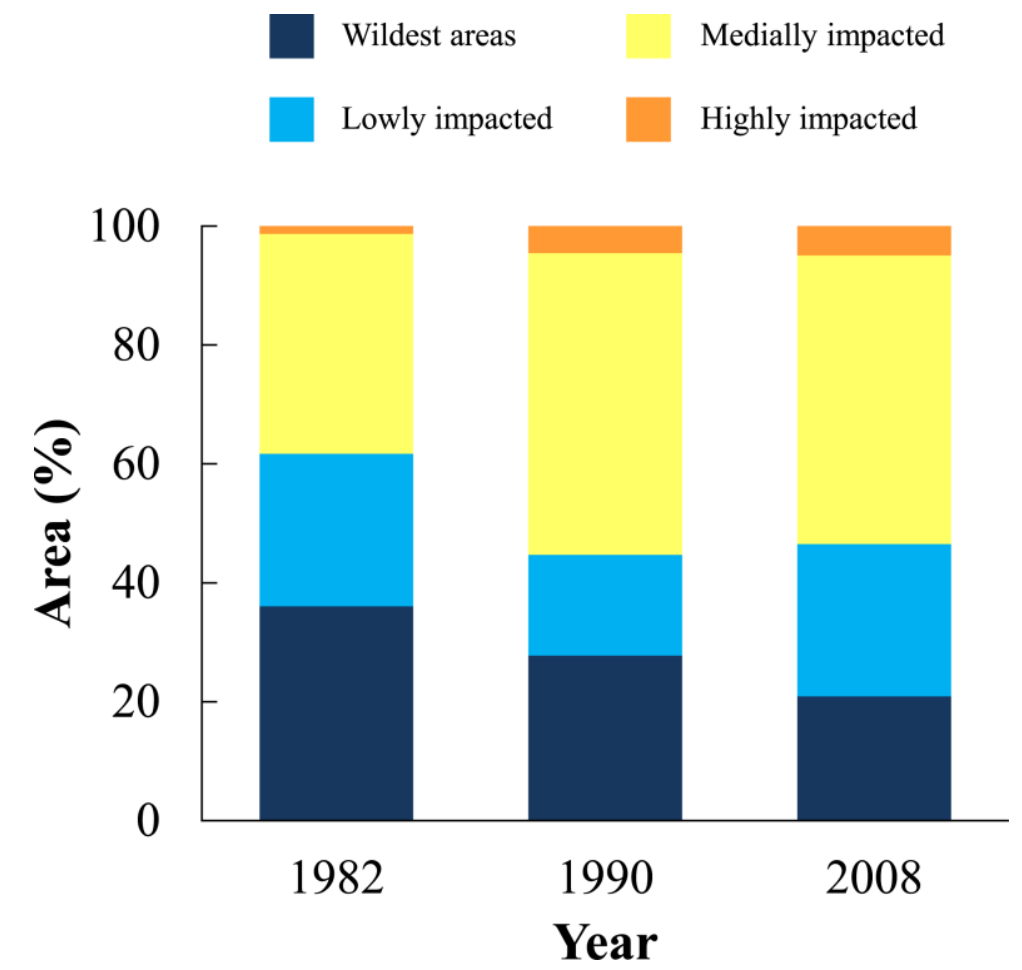

Figure 3.4 Contribution of the four different categories of human pressure to the total study area in each of the three study years.

Comparing the change rates obtained for the two analyzed periods (Figure 3.5A-B), it becomes apparent that during the first period (1982-1990) large areas showed a high increase of HF. However, for the second period (1990-2008) most of the territory 
maintained the same levels of HF and only a small proportion showed an increase. For both periods there were areas with decreasing human pressure, while these areas in the first period are agglomerated in the second, they are more dispersed. Likewise, some important "hotspots of change" (Figure 3.5C) were identified in the study region. The analysis showed two centers of rapid human pressure increase in the western part of the study area (Figure 3.5D-E), one of them (Figure 3.5E) located in an area of seasonal dry forest (SDF) with high conservation value. The biggest front (Figure 3.5F) was located along the Rio Zamora which currently is one of the most important agricultural sectors in the Amazon region of the study area. But the "hotspots of change" are not restricted to areas with high productivity they are also found in areas with high recreational value like the Malacatos and Vilcabamba valleys (Figure 3.5G). 

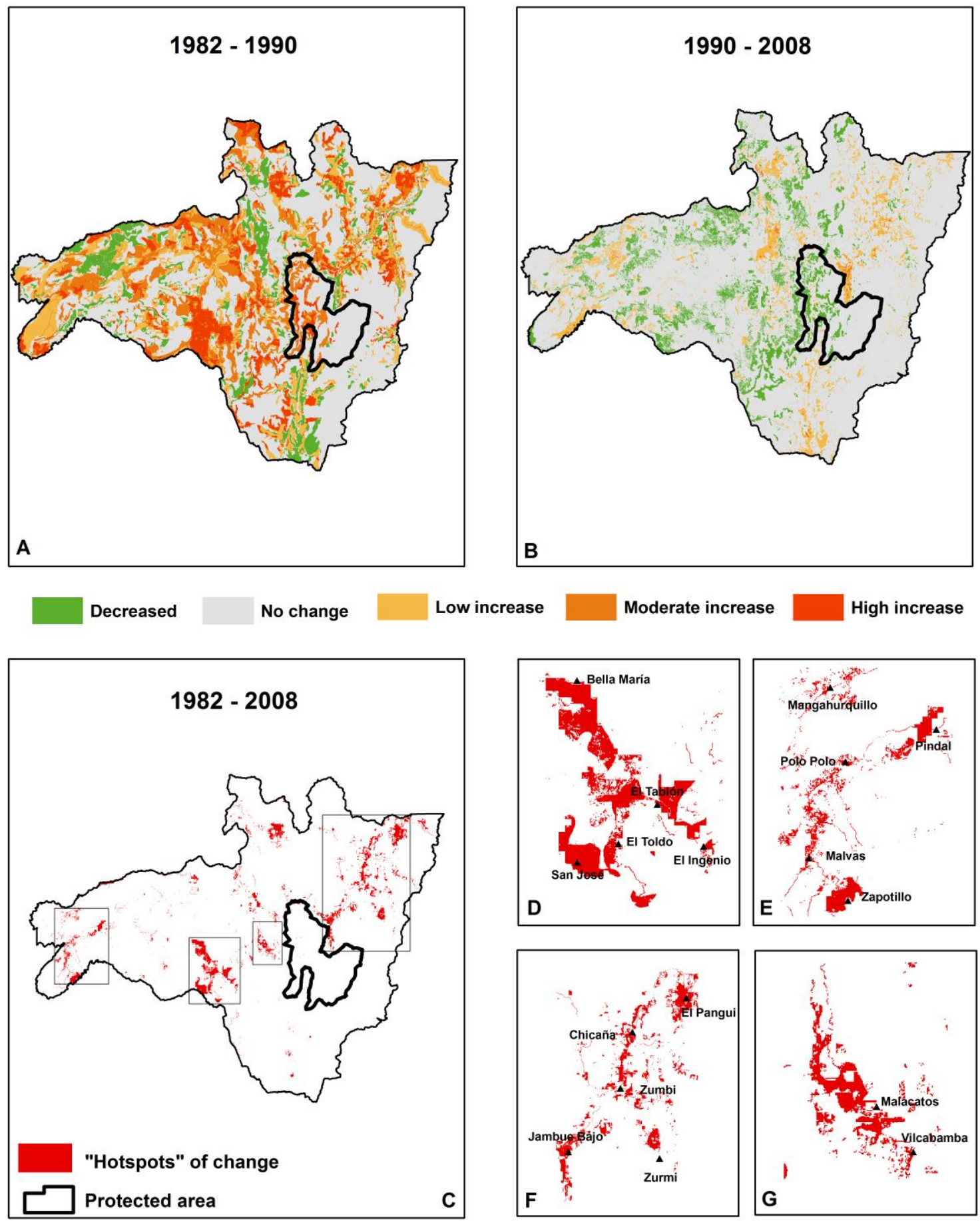

Figure 3.5 A. Map of HF change rates for the periods 1982-1990 and B. 1990-2008. C. "hotspots of change" map that shows areas with a high increase in the levels of HF since 1982. D. South of the Loja province in the western escarpments of the Andes. E. Seasonally dry forest ecosystems in the western part of the Loja Province. F. Rio Zamora basin. G. Valleys of Malacatos and Vilcabamba. 


\subsubsection{Human impact on different vegetation types}

When we analyzed the evolution of the HF in the different vegetation types (Figure 3.6) we observed in all of them a reduction of wildest areas during our study periods. This reduction was more pronounced in the montane evergreen forest where more than a third of the wildest areas in 1982 progressed to a higher degree of human impact until 2008. The páramo was the second vegetation type where wildest areas predominated in 1982, but unlike the montane evergreen forest the share of wildest areas in the páramo remained about the same, in 1990 there was an increase in the level of human pressure, but by 2008 these values fell again. In the premontane evergreen forest, the wildest areas and the areas with low impact levels decreased over the study period, and the area with moderate impact had a significant increment from 1982 to 2008 . The seasonally dry forest and the shrubland were the two vegetation types exposed to the highest levels of human pressure. In 1982 both vegetation types had already over $60 \%$ of their area within the categories of moderate and high impact.

Table 3.2 The correlation coefficients $\left(R^{2}\right)$ between the observed HF values in the five natural vegetation types and the human proxies analyzed.

\begin{tabular}{lccccc}
\hline \hline & PMEF & MEF & PA & SL & SDF \\
\hline Human access & 0.47 & 0.30 & 0.07 & 0.36 & 0.16 \\
$\begin{array}{l}\text { Human density } \\
\begin{array}{l}\text { Land } \\
\text { transformation }\end{array}\end{array}$ & 0.62 & 0.65 & 0.41 & 0.65 & 0.61 \\
$\begin{array}{l}\text { Power } \\
\text { infrastructure }\end{array}$ & 0.32 & 0.59 & 0.65 & 0.39 & 0.44 \\
\hline \hline
\end{tabular}

The p-values for all shown relations where $<0.0001$

The analysis of the relationship between the HF and the four human proxies revealed that in most of the vegetation types, human density was a good predictor (above 60\%) of the observed HF, with the exception of the páramo where land transformation had a stronger impact (Table 3.2). The accessibility was the second most important factor in the premontane evergreen forest. The contribution of power infrastructure was significant in the shrubland, in contrast in the Páramo there were no registers of power infrastructure. 
PMEF

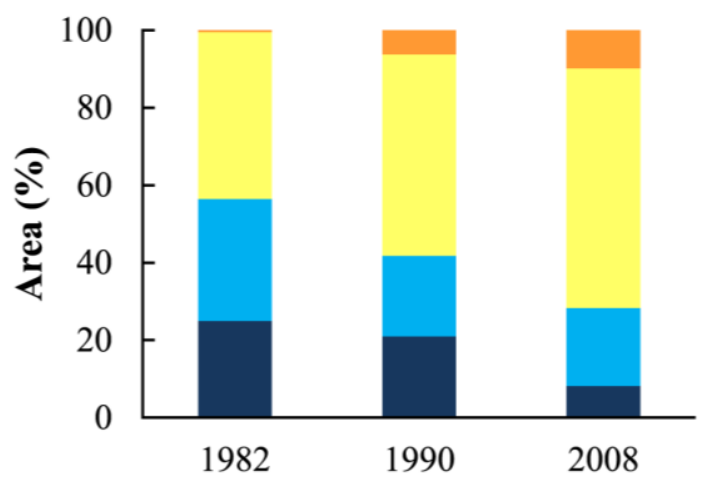

$\mathrm{Pa}$

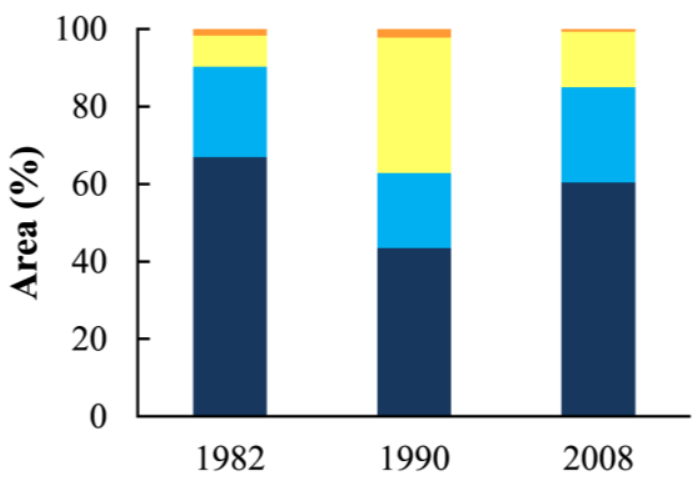

SDF

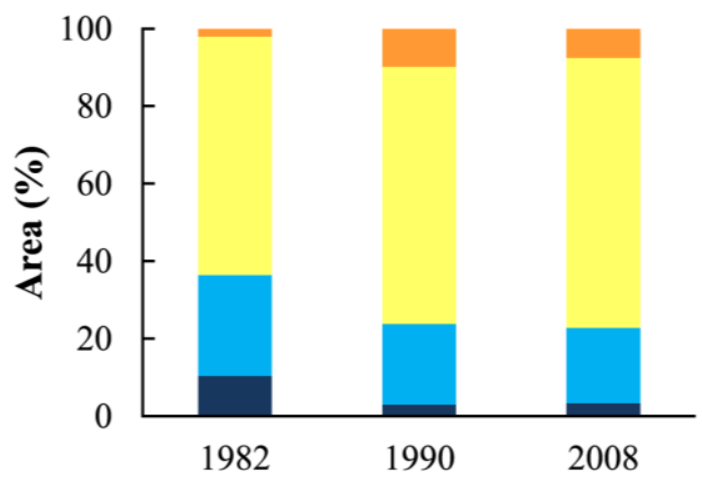

MEF

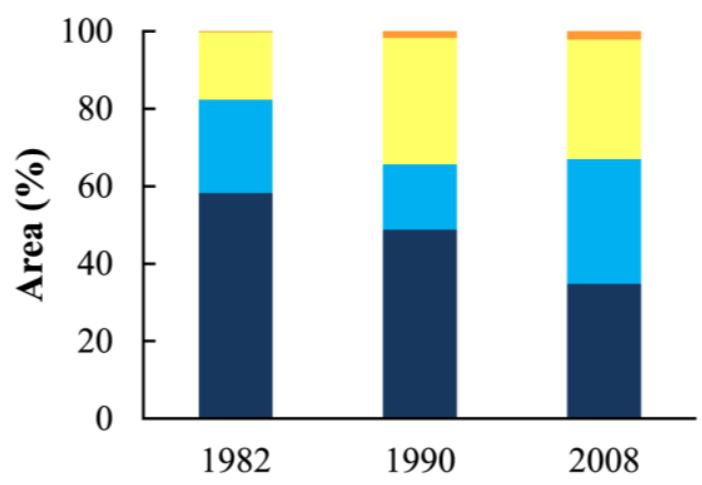

SI

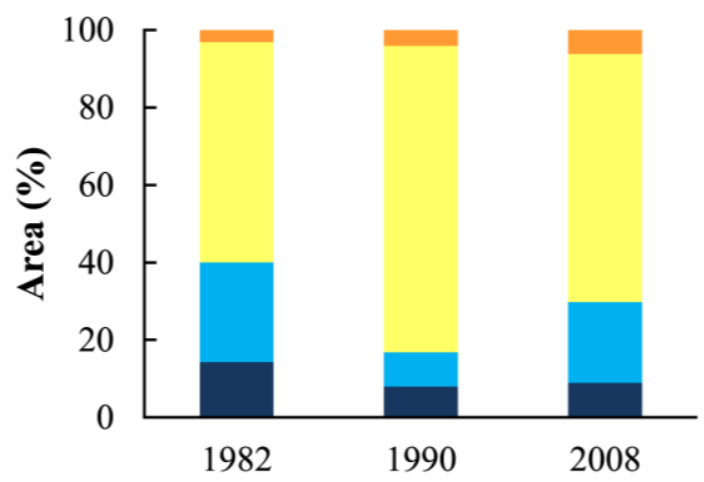

Wildest areas

Lowly impacted

Medially impacted

Highly impacted

Figure 3.6 Variation of human footprint in the five vegetation types in South Ecuador during the period from 1982 - 2008(PMEF: premontane evergreen forest, MEF: montane evergreen forest, PA: páramo, SL: shrubland, SDF: seasonally dry forest). 


\subsubsection{Effectiveness of protected areas}

The analysis of protected area effectiveness showed strong differences between the HF values observed in the landscape compared with those observed in the buffer zone and inside the PNP. Despite these differences, there was a common progressive increase in the human pressure levels during the study period (Figure 3.7). For 1982 the mean HF inside the PNP was 1, indicating that there was almost no human pressure. For 1990 a slight increase in the mean HF value was recorded in the innermost areas of the PNP that decreased again until 2008. However, at the edges and the periphery of the PNP, the HF increased between 1982 and 1990 (from 3 to 9) stayed stable in 2008. For the three analyzed years, the mean HF values for all sample areas inside PNP remained below 10 and thus well below the values observed in the buffer area (range from 11 to 18) and the adjacent landscape (range from 15 to 27). In contrast to the PNP, in the buffer areas, there was an increase in the mean HF. The most distanced areas to the PNP showed the higher mean HF. Mean HF values registered in the buffer zone were lower than those of the landscape baseline. 

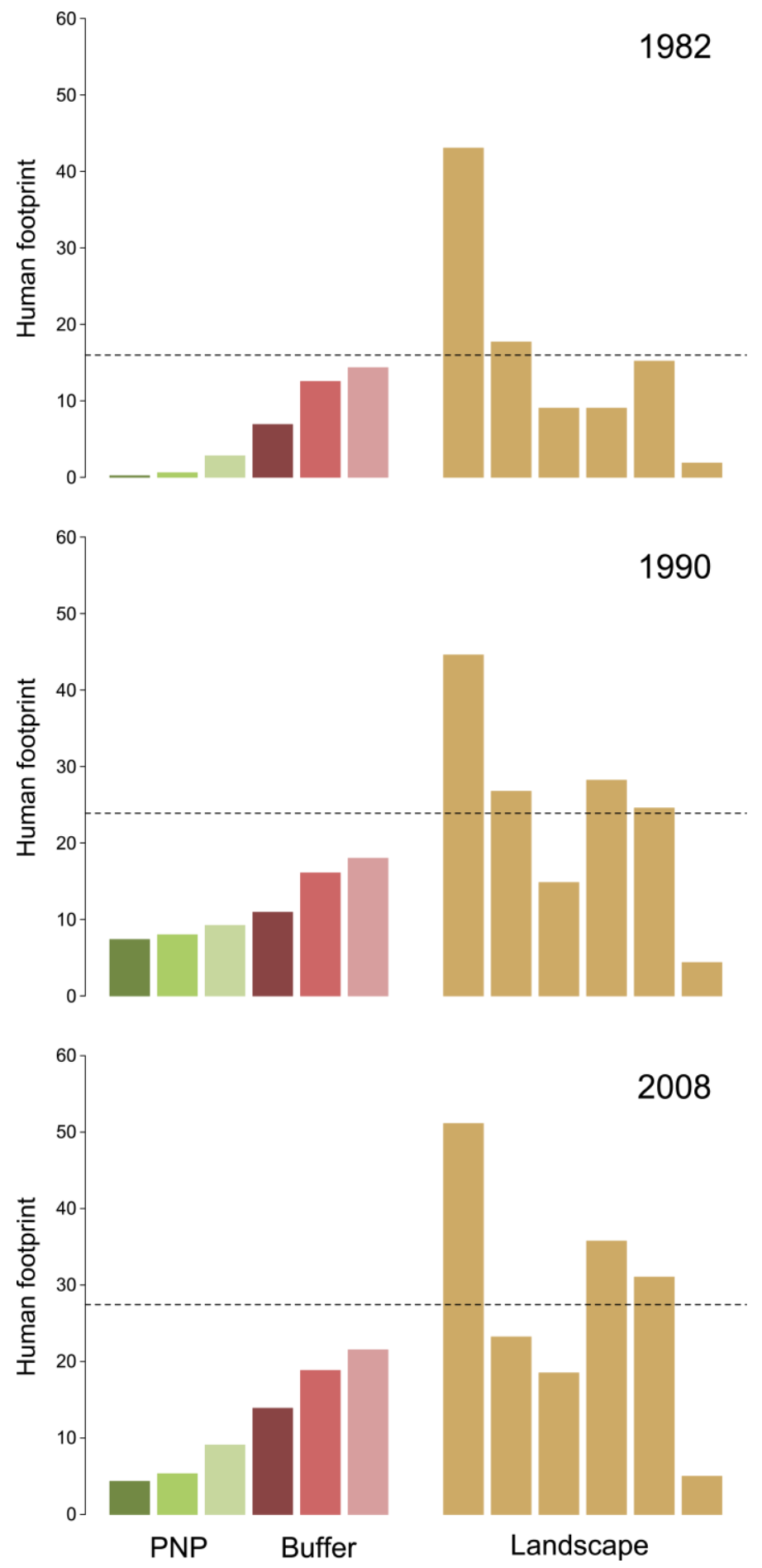

Figure 3.7 Variation of human pressure in the different study years within and around Podocarpus National Park (PNP). The dashed line represents the mean value of HF observed in the six landscape areas. Bars in shades of green represent the areas inside PNP, the bars in shades of red represent the areas outside the PNP and the brown bars represent the different landscape parcels (compare to Figure 2). 


\subsection{Discussion}

\subsubsection{Patterns of human footprint in South Ecuador}

The interactions of humans with the territory are complex, but the understanding of these interactions through spatial tools like HF analysis is a way to improve land management. The spatial and temporal analysis of HF for South Ecuador shows not only an ongoing increase in the levels of human pressure in most of the territory but also inconsistent patterns in how these changes have occurred in the different vegetation types that characterize the study area.

In 1982, the study area already had more than half of its territory under human influence reflecting historic patterns of human colonization, especially in the western part which has more suitable climatic conditions for human settlements and agriculture compared to the humid climate and the challenging topography of the Andes in the eastern part of the study area. Despite the increasing levels of human pressure until 2008, South Ecuador has still little territory under high levels of HF and a great proportion under the categories "wildest areas $=21 \%$ " and "Low impact areas $=26 \%$ ".

About half of the territory classified as "wildest area" and "lowly impacted" is under some protection category which means that the remaining unprotected territory contains many areas suitable for conservation. In addition to those areas that should be preserved strictly, the low impacted areas (with some low grade of conversion, more fragmented, with a small extension, and generally dominated by secondary forest and under private ownership), could be incorporated into other forms of management or conservation to preserve the biodiversity and environmental services. As Chazdon et al. (2009) mentioned, in the face of the rapid conversion of pristine areas, the secondary forests have a valuable role being the refuge for old-growth species and promoting landscape connectivity.

Although only 5\% of the territory have high levels of HF and there are good opportunities for conservation, the actions must be taken as soon as possible. During the last years, the Ecuadorian government has undertaken several development projects as part of its public politics, which includes the improvement of the road network, the increasing of accessibility with new roads and the implementation of new hydroelectric and mining 
projects (SENPLADES, 2013). These changes will strongly influence the territorial dynamics and human pressure patterns in the region. Several studies have shown a positive relation between roads, human density and land cover change (e.g. Finer et al., 2008; Laurance et al., 2002; Mertens et al. 2002). Road opening facilitates access to areas previously not colonized allowing new settlements, increasing and facilitating resource extraction and promoting land-use changes (Laurance et al., 2009, 2014).

In the case of mining projects the change of the local economic situation could promote population growth by immigration, increasing resource consumption as a result of higher affluence, thereby providing a basis for other land use activities and further frontier expansion (Barreto et al. 2006; Bezerra et al., 1996; Dietz et al., 2007; Myers and Kent, 2003). This paper also aims to serve to lay the foundations for a characterization of human impact just before the start of these new mining projects in order to assess the future impact of them in South Ecuador.

Another important aspect to be analyzed and proposed for future research is the study of the relation between deforestation and human pressure. As demonstrated in our study most of the territory shows medium levels of HF. However, Tapia-Armijos et al. (2015) reported that South Ecuador is under an intense fragmentation and deforestation process with a registered annual deforestation rate of $2.86 \%$ for the $1989-2008$ period. This suggests that the relation between human pressure and deforestation is not always direct at landscape level and that even in areas with low HF forests could be threatened.

The temporal analysis of HF showed that the changes in the HF values were more intense in the first period 1982-1990. Most of the areas with moderate and high increase were urban areas (county seats) that experienced population growth. South Ecuador like other tropical regions undergoes a constant process of urbanization where rural people migrate to urban areas seeking to improve their incomes and to get access to better health and educational services (Grau and Aide, 2007).

Regarding human influence, the urbanization process represents a higher environmental degradation in the urban centers (e.g. increase in air and water pollution) but also an increase of pressure in rural areas by a displacement of land transformation. On the one 
hand, rural areas act as food suppliers for urban centers and on the other hand the decrease of population promote the transition from small-scale agriculture to extensive agriculture as monocultures and cattle ranching (e.g. Pichón, 1997) which demands less labor per land area but also results in a more transformed land.

The second conspicuous pattern for this period is the presence of areas with a reduction of $\mathrm{HF}$ and a declination of population in the western part of the study area in contrast to areas with high increase in $\mathrm{HF}$ and increase of population in the eastern part (Amazon region) indicating that there was not only migration to urban areas but also to new colonization fronts. This internal migration coincided with two factors. The western part of the area was exposed to a series of severe droughts in the past and the second factor is the promulgation of the agrarian reform in 1964 by which the Ecuadorian government supported the arrival of colonists in the Amazon region giving land titles to those who proved that the newly colonized land was productive (Mena, 2008; Zevallos, 1989). Between 1990 and 2008 the $\mathrm{HF}$ in most of the territory remained unchanged probably because many of these sites were already transformed.

In the western part, we observed a decreased in the levels of human pressure whereas many of the areas with a high and moderate increase were located in the northeastern of the study area. These patterns could be explained by several demographic and socioeconomic processes that occurred since 1990. For instance, as a result of the 90's Ecuadorian economic crisis, the international migration increased, and it was the western part of the study area which contributed a high proportion of migrants. This decrease in the population density in some rural areas of the Loja province and also the remittances from migrants have affected this pattern. In the case of the northeastern part, land transformation appears to be the main cause of the high levels of human pressure as result of the expansion of the agricultural frontier around the new colonization fronts founded the last decade. Of course, the dynamics at territorial level are complex, and this study did not analyze other variables (e.g. poverty indices, production, affluence, economic activities, land suitability for agriculture) that also contribute to the observed changes. 


\subsubsection{Patterns of human footprint in the different vegetation types}

The analysis of HF for the different natural vegetation units showed a gradient of human impact with low altitudes exhibiting higher levels of human pressure. According to Geist and Lambin (2001) lowlands and foothills are usually more suitable for colonization, infrastructure construction, and cattle ranching.

From the five vegetation types analyzed, the seasonally dry forests and shrublands historically had been those with most anthropogenic impact with direct effects on their conservation status. At global level, Ecuador has a low extension of dry ecosystems and the most representative surface is in South Ecuador (Espinosa et al., 2012). If our results show that South Ecuadorian dry forest are highly impacted, and these are the most representative remaining in the country, we can conclude that not only at regional level but also at country level this ecosystem is highly threatened. This is supported by Portillo-Quintero and Sánchez-Asofeifa (2010) who mentioned that Ecuador is one of the countries with the highest proportion of critical size fragments of dry forest and the low surface under conservation.

The increase in the levels of human pressure in the premontane evergreen forest (PMEF) seems to have a direct relation to accessibility. The PMEF located in the eastern lowlands of South Ecuador had been colonized since the 1960's. In that time there were few roads in the area, but the navigable rivers were used to access areas previously not colonized, like in other Amazon regions (e.g. Barreto et al., 2006). In the PMEF the biggest front of change of HF is following the main course of the Rio Zamora, an area that was also identified by Tapia-Armijos et al. (2015) as a hotspot of deforestation in the region.

In the case of páramo and montane evergreen forest, both are the natural vegetation types with more surfaces still included within the category "wildest". Many of the regional protected areas include MEF and $\mathrm{Pa}$, and this may have contributed to the low increase of HF in both natural ecosystems.

In the SDF human access showed only a small contribution despite the presence of many access roads (both variables used to model human access). We assume that our model 
underestimates the impact of human access in this vegetation type because it did not include illegal and not officially mapped roads opened by locals.

\subsubsection{Effectiveness of protected areas}

Protected areas typically are embedded in human-dominated landscapes (DeFries et al., 2007; Wittemyer et al., 2008) which have a direct impact on the effectiveness of these areas to reach their conservation objectives.

Our analysis showed that the PNP seems to have been largely successful in avoiding human pressure inside its boundaries since the observed increase in the levels of human pressure during the study period was less than that observed in the unprotected surrounding area.

This tendency also was observed in other protected areas around the world, Bruner et al. (2001) concluded that almost all parks are under pressure inside their boundaries although it is low and in most cases (about 80\%) the parks presented better conditions than their surrounding areas.

The buffer zones of protected areas support higher levels of human impact, and it conditions the ecological functioning of the reserves (Hansen and DeFries, 2007). Our results showed that some of the principal "hotspots of change" of HF are located along the northwestern and northeastern edges of PNP, the area of Timbara (Jambue bajo, Fig. 5F) for example had experienced accelerated demographic growth (Wever, 2010) which subsistence economy is based on small-scale agro-pastoral activities with a high engage of cattle ranching (Pohle, 2008). In contrast, the two south fronts of PNP had not seen major changes.

Despite the increase of human pressure in some areas of the PNP buffer zone since 1982, the values of HF have remained below the baseline in the landscape, which means that there is not an evident process of leakage. Oliveira et al. (2007) reported an increase in deforestation rates in the surrounding landscape of a restricted land use area in the Peruvian Amazon but a decrease of deforestation rates inside it. In these cases, considering only what happened in the reserve may lead to a false perception of the reality. Having spatial and temporal information of HF patterns allowed us to have a better perception of how human 
pressure behaved after the legalization of PNP. However, the absence of leakage but the slight increase of HF values inside the reserve and in the buffer zone showed that the implementation of additional conservation and management strategies in the PNP influence area is necessary (e.g. the implementation of private reserves or ecotourism projects).

At landscape level, we registered that the PNP does mitigate human pressure inside its limits and to a smaller extent in its buffer zone, but not in the surrounding area.

\subsection{Conclusions}

The speed of global change undoubtedly poses a challenge to the conservation of natural ecosystems, especially in areas with high biodiversity. In the world, most of the hotspots of biodiversity tolerate high levels of human pressure (Venter et al., 2016) and South Ecuador is no exception. Although there is still a significant fraction of low levels of human pressure, there are also several areas with a significant increase of HF levels. These patterns are common in high biodiversity areas (e.g. the Amazon still conserves the largest area of tropical forest, but has import hotspots of changes with annual deforestation rates above 4\%). Many of these areas are located in countries with developing economies based on resource extraction, high rates of unmet needs and poor legal systems and also with limited economic resources for conservation and monitoring programs. As a consequence of these limitations, many of these countries have not invested in creating spatial indicators systems that allow them to allocate more resources to conservation and management. In this context, the HF developed by Sanderson et al. (2002) and adapted at local scale is a useful spatial tool that improves our understanding of the spatial dynamics in the territory and to generate baseline information for the detection of areas where natural resource management and conservation efforts should focus.

One of the positive aspects of this tool is that it generates valuable information from basic spatial information (e.g. population, road and electrical infrastructure) that any country may have available and therefore is feasible to reproduce in other areas. For instance, in this study the HF allowed us not only to understand the variations of human pressure patterns during 1982-1990 and 1990-2008 but also to identify the principal areas where the human 
pressure has intensified during this time, the areas that conserve low levels of human pressure and therefore potentially could be included under protection.

Unlike a limiting factor could be the spatial and temporal availability of human proxies' information which may limit our understanding of the complex dynamics that occur at territorial level. For instance, this paper does not analyses other variables that also influence the levels of human pressure that a territory support (e.g. poverty indices, production levels, affluence, technologies, economic activities, suitability for agriculture and others) and the definition of the studied years (1982, 1990 and 2008) was the result of the available geographic information. Finally, although the HF provides spatial information of human pressure in a region it does not give information about the ecological impact that human pressure produces or about the biological responses of species to these impacts. A better ecological approach may be to include other variables that represent the ecological effect.

\subsection{Acknowledgments}

We thank C.I. Espinosa for manuscript revision and commentaries and C. Iñiguez-Armijos for his comments on figures. This research was financially supported by SENESCYT scholarship program 2010 and the DFG within the research unit FOR 816 (projects HO 3296/2 and HO 3293/3). D. Draper Munt is funded by the Portuguese Foundation for Science and Technology (FCT) by the post-doc grant SFRH/BPD/100384/2014. We thank two anonymous reviewers for their suggestions that improved our manuscript.

\subsection{References}

Balslev, H., Ollgaard, B. (2002) Mapa de vegetación del Sur del Ecuador. In: Aguirre, Z., Madsen, J.E., Cotton, E., Balslev, H., editors. Botánica Autroecuatoriana-Estudios sobre los recursos vegetales en las provincias de El Oro, Loja y Zamora Chinchipe, Ediciones ABYA YALA, Quito-Ecuador. 
Barreto, P., Souza Júnior, C., Nogueron, R., Anderson, A., and Salomão, R. (2006). Human pressure on the Brazilian Amazon forest. World Resources Institute-WRI/Instituto do Homem e Meio Ambiente da Amazônia-IMAZON.

Bendix, J., and Lauer, W. (1992). Die Niederschlagsjahreszeiten in Ecuador und ihre klimadynamische Interpretation. Erkunde; 46, 118-134.

Bezerra, O., Verissimo, A., and Uhl, C. (1996). The regional impacts of small-scale gold mining in Amazonia. In Natural Resources Forum (Vol. 20, No. 4, pp. 305-317). Blackwell Publishing Ltd.

Bruner, A. G., Gullison, R. E., Rice, R. E., and Da Fonseca, G. A. (2001). Effectiveness of parks in protecting tropical biodiversity. Science, 291(5501), 125-128.

Chazdon, R. L., Peres, C. A., Dent, D., Sheil, D., Lugo, A. E., Lamb, D., and Miller, S. E. (2009). The potential for species conservation in tropical secondary forests. Conservation Biology, 23(6), 1406-1417.

Cueva, J., Chalán, L. (2010) Cobertura Vegetal y Uso Actual del Suelo de la Provincia de Loja. Informe Técnico Departamento de Sistemas de Información Geográfica de Naturaleza \& Cultura Internacional, Loja: Gráficas Amazonas.

de Cos Guerra, O. (2004). Valoración del método de densidades focales (Kernel) para la identificación de los patrones espaciales de crecimiento de la población en España. Geofocus: Revista Internacional de Ciencia y Tecnología de la Información Geográfica, (4), 16.

DeFries, R., Hansen, A., Newton, A. C., and Hansen, M. C. (2005). Increasing isolation of protected areas in tropical forests over the past twenty years.Ecological Applications, 15(1), 19-26.

DeFries, R., Hansen, A., Turner, B. L., Reid, R., and Liu, J. (2007). Land use change around protected areas: management to balance human needs and ecological function. Ecological Applications, 17(4), 1031-1038. 
Dietz, T., Rosa, E. A., \& York, R. (2007). Driving the human ecological footprint. Frontiers in Ecology and the Environment, 5(1), 13-18.

Ellis, E. C., and Ramankutty, N. (2008). Putting people in the map: anthropogenic biomes of the world. Frontiers in Ecology and the Environment, 6(8), 439-447.

Elvidge, C.D., Baugh, K.E., Kihn, E.A., Kroehl, H.W., Davis, E.R. (1997b). Mapping city lights with nighttime data from the DMSP Operational Linescan System. Photogrammetric Engineering and Remote Sensing. 63: 727-734.

Emck, P. (2007). A climatology of South Ecuador with special focus on the major Andean ridge as Atlantic-Pacific climate divide. PhD thesis, University of Erlangen-Nürnberg.

Espinosa, C.I., de la Cruz, M., L. Luzuriaga, A. Escudero, A.(2012). Bosques tropicales secos de la región Pacífico Ecuatorial: diversidad, estructura, funcionamiento e implicaciones para la conservación. Ecosistemas 21 (1-2): 167-179. Ecosistemas, 21, 1.

Eastman, J. R. (2015). TerrSet: Geospatial Monitoring and Modeling Software.Clark Labs, Clark University.

Ewers, R. M., and Rodrigues, A. S. (2008). Estimates of reserve effectiveness are confounded by leakage. Trends in Ecology and Evolution, 23(3), 113-116.

Farr, T.G., Rosen, P.A., Caro, E., Crippen, R., Duren, R., Hensley, S., et al. (2007) The Shuttle Radar Topography Mission. Reviews of Geophysics; 45 (2).

Finer, M., Jenkins, C. N., Pimm, S. L., Keane, B., and Ross, C. (2008). Oil and gas projects in the western Amazon: threats to wilderness, biodiversity, and indigenous peoples. PLoS ONE, 3(8): e2932

Geist, H.J., Lambin, E.F. (2001). What Drives Tropical Deforestation? A MetaAnalysis of Proximate and Underlying Causes of Deforestation Based on Subnational Case Study Evidence. Louvain-la-Neuve (Belgium): LUCC International Project Office, LUCC Report Series no. 4 
Goudie, A. S. (2013). The human impact on the natural environment: past, present, and future. Wiley-Blackwell.

Grau, H.R., and Aide, T.M. (2007). Are rural-urban migration and sustainable development compatible in mountain systems?. Mountain Research and Development, 27(2), 119123.

Haines, A. M., Leu, M., Svancara, L. K., Scott, J. M., and Reese, K. P. (2008). A theoretical approach to using human footprint data to assess landscape level conservation efforts. Conservation Letters, 1(4), 165-172.

Halpern, B.S., Walbridge, S., Selkoe, K.A., Kappel, C.V., Micheli, F., D'Agrosa, C. and Watson, R. (2008). A global map of human impact on marine ecosystems. Science, 319(5865), 948-952.

Hansen, A.J., and DeFries, R. (2007). Ecological mechanisms linking protected areas to surrounding lands. Ecological Applications, 17(4), 974-988.

Homeier, J., Breckle, S. W., Günter, S., Rollenbeck, R. T., \& Leuschner, C. (2010). Tree Diversity, Forest Structure and Productivity along Altitudinal and Topographical Gradients in a Species-Rich Ecuadorian Montane Rain Forest.Biotropica, 42(2), 140148.

Homeier, J., Werner, F.A., Gradstein, S.R. (2008). Potential vegetation and floristic composition of Andean forests in South Ecuador, with a focus on the RBSF. In: Beck E, Bendix J, Kottke I, Makeschin F, Mosandl, editors. Gradients in a Tropical Mountain Ecosystem of Ecuador: Ecological Studies, Berlin: Springer; pp 87-100.

Instituto Geográfico Militar (IGM). (2011). Base escala 1:50000.

Instituto Nacional de Estadísticas y Censos (INEC). (1982). Censo de Población y Vivienda. Quito.

Instituto Nacional de Estadísticas y Censos (INEC). (1990). Censo de Población y Vivienda. Quito. 
Instituto Nacional de Estadísticas y Censos (INEC). (2010). Censo de Población y Vivienda. Quito.

Laurance, W.F., Albernaz, A.K., Schroth, G., Fearnside, P. M., Bergen, S., Venticinque, E. M., and Da Costa, C. (2002). Predictors of deforestation in the Brazilian Amazon. Journal of Biogeography, 29(5-6), 737-748.

Laurance, W.F., Goosem, M., and Laurance, S.G. (2009). Impacts of roads and linear clearings on tropical forests. Trends in Ecology and Evolution, 24(12), 659-669.

Laurance, W. F., Clements, G. R., Sloan, S., O’Connell, C. S., Mueller, N. D., Goosem, M., ... \& Van Der Ree, R. (2014). A global strategy for road building. Nature, 513(7517), 229232.

McKee, J. K., Sciulli, P. W., Fooce, C. D., and Waite, T. A. (2004). Forecasting global biodiversity threats associated with human population growth. Biological Conservation, 115(1), 161-164.

Mena, C. (2008). Trajectories of Land-use and Land-cover in the Northern Ecuadorian Amazon: temporal composition, spatial configuration and probability of change. Photogrammetric Engineering and Remote Sensing, 6, 737-751.

Mertens, B., Poccard-Chapuis, R., Piketty, M.G., Lacques, A.E., and Venturieri, A. (2002). Crossing spatial analyses and livestock economics to understand deforestation processes in the Brazilian Amazon: the case of Sao Felix do Xingu in South Para. Agricultural Economics, 27(3), 269-294.

Ministerio de Agricultura, Ganadería, Acuacultura y Pesca (MAGAP). (1982). Mapa de cobertura vegetal del Ecuador continental, Escala 1:250000. Quito.

Ministerio de Agricultura, Ganadería, Acuacultura y Pesca (MAGAP). (1990). Mapa de cobertura vegetal del Ecuador continental, Escala 1:250000. Quito.

Myers, N., \& Kent, J. (2003). New consumers: the influence of affluence on the environment. Proceedings of the National Academy of Sciences, 100(8), 4963-4968. 
Oliveira, P.J., Asner, G.P., Knapp, D. E., Almeyda, A., Galván-Gildemeister, R., Keene, S., and Smith, R.C. (2007). Land-use allocation protects the Peruvian Amazon. Science, 317(5842), 1233-1236.

Peters, T., Drobnik, T., Meyer, H., Rankl, M., Richter, M., Rollenbeck, R, Thies, B. \& Bendix, J. (2013). Environmental changes affecting the Andes of Ecuador. InEcosystem Services, Biodiversity and Environmental Change in a Tropical Mountain Ecosystem of South Ecuador (pp. 19-29). Springer Berlin Heidelberg.

Pichón, F.J. (1997). Settler households and land-use patterns in the Amazon frontier: farmlevel evidence from Ecuador. World Development, 25(1), 67-91.

Pohle, P. (2008). The people settled around Podocarpus National Park. In: Beck E., Bendix J., Kottke I., Makeschin F., Mosandl R., editors. Gradients in a Tropical Mountain Ecosystem of Ecuador: Ecological Studies. Springer, pp 25-36. Berlin.

Portillo-Quintero, C.A., and Sánchez-Azofeifa, G.A. (2010). Extent and conservation of tropical dry forests in the Americas. Biological Conservation,143(1), 144-155.

Pressey, R.L., Cabeza, M., Watts, M.E., Cowling, R.M., and Wilson, K.A. (2007). Conservation planning in a changing world. Trends in Ecology and Evolution, 22(11), 583-592.

Richter, M., Diertl, K.H., Emck, P., Peters, T., \& Beck, E. (2009). Reasons for an outstanding plant diversity in the tropical Andes of Southern Ecuador.Landscape Online, 12(2009), 1-35.

Sanderson, E.W., Jaiteh, M., Levy, M.A., Redford, K.H., Wannebo, A.V., and Woolmer, G. (2002). The Human Footprint and the Last of the Wild: the human footprint is a global map of human influence on the land surface, which suggests that human beings are stewards of nature, whether we like it or not.BioScience, 52(10), 891-904.

SENPLADES, S. N. (2013). Plan Nacional de Desarrollo/Plan Nacional para el Buen Vivir 2013-2017. 
Sierra, R. (199). Vegetación Remanente del Ecuador Continental Scale: 1:1,000,000 Proyecto 426 INEFAN/GEF-BIRF, Wildlife Conservation Society and EcoCiencia, Quito-Ecuador.

Tapia-Armijos, M.F., González, J., Valdivieso, M., Bravo, F., Espinosa, C.I. (2011). Cobertura Vegetal y Uso Actual del Suelo de la Provincia de Zamora Chinchipe. Informe Técnico, Loja: Universidad Técnica Particular de Loja.

Tapia-Armijos, M.F., Homeier, J., Espinosa, C.I., Leuschner, C., and de la Cruz, M. (2015). Deforestation and Forest Fragmentation in South Ecuador since the 1970s-Losing a Hotspot of Biodiversity. PloS one, 10(9), e0133701.

Tosi, J.A., and Voertman, R.F. (1964). Some environmental factors in the economic development of the tropics. Economic Geography, 189-205.

Venter, O., Sanderson, E. W., Magrach, A., Allan, J. R., Beher, J., Jones, K. R., ... \& Levy, M. A. (2016). Sixteen years of change in the global terrestrial human footprint and implications for biodiversity conservation. Nature Communications, 7.Vitousek, P.M. (1994). Beyond global warming: ecology and global change.Ecology, 75(7), 18611876.

Watson, J. E., Shanahan, D. F., Di Marco, M., Allan, J., Laurance, W. F., Sanderson, E. W., Mackey, B. \& Venter, O. (in press). Catastrophic Declines in Wilderness Areas Undermine Global Environment Targets. Current Biology. Doi: 10.1016/j.cub.2016.08.049

Weigend, M. (2002). Observations on the biogeography of the Amotape-Huancabamba zone in northern Peru. The Botanical Review, 68(1), 38-54.

Weinzettel, J., Hertwich, E. G., Peters, G. P., Steen-Olsen, K., \& Galli, A. (2013). Affluence drives the global displacement of land use. Global Environmental Change, 23(2), 433-438.

Wever, F. (2010). The demographic development of the National Park Region Podocarpus in Southern Ecuador. Master thesis. University of Greifswald. 
Wittemyer, G., Elsen, P., Bean, W.T., Burton, A. C. O., and Brashares, J. S. (2008). Accelerated human population growth at protected area edges. Science,321(5885), 123-126.

Wolf, K., Veldkamp, E., Homeier, J., Martinson, G.O. (2011). Nitrogen availability links forest productivity, soil nitrous oxide and nitric oxide fluxes of a tropical montane forest in southern Ecuador. Global Biogeochemical Cycles; 25(4).

Woolmer, G., Trombulak, S. C., Ray, J. C., Doran, P. J., Anderson, M. G., Baldwin, R. F., ... and Sanderson, E. W. (2008). Rescaling the human footprint: a tool for conservation planning at an ecoregional scale. Landscape and Urban Planning, 87(1), 42-53.

York, R., Rosa, E. A., \& Dietz, T. (2003). Footprints on the earth: The environmental consequences of modernity. American sociological review, 279-300.

Zevallos, L. (1989). Agrarian reform and structural change: Ecuador since 1964. In: Thiesenhusen, W. C. Searching for agrarian reform in Latin America, pp. 42-69. Unwin Hyman. Winchester. 


\subsection{Appendix}

\subsubsection{Human population density}

To map the influence of human population density we used as starting data the population information from the Ecuadorian National Census at parish level (Table 3.1), which is the lowest political and administrative division Ecuador and the smallest census unit. However, the population density values at parish level associated one unique density value to a political boundary (polygon) without considering the specific localities (cities or towns) where the population is distributed. To obtain continuous information that reflects a more realistic distribution of population densities throughout the territory (de Cos Guerra, 2004) we assigned to each pixel the proportion of population density corresponding to each parish (INEC, 1982; 1990; 2010) using a Kernel density method with a bandwidth of $9 \mathrm{~km}$ and 17 $\mathrm{km}$ in urban and rural parishes, respectively.

\subsubsection{Land transformation}

To map land transformation we used four data sets per study year (Table 3.1) (land cover, cities, other human settlements, and roads) which were combined in a single layer. Unlike the layer of major cities, the only available information about other human settlements was a layer of points. To create more realistic information about the influence or human settlements we used this point layer to create buffer areas around the points considering the influence that each type of settlement (main towns, urban and rural towns) could have in the territory. We created a buffer of $1 \mathrm{~km}$ around main towns, $0.5 \mathrm{~km}$ buffer around urban towns and $0.25 \mathrm{~km}$ buffer around rural towns. The information of population centers (major cities and other human settlements) was added to the land cover maps of each year assuming that settlement geographic expansion has remained more or less uniform. In the land transformation dataset, we also included the roads. Major and minor roads were obtained from the Sistema Nacional de Información (SNI), except the period 1969 which was extracted from Peters et al. (2013).

We assigned the HII maximum score (10) to human settlements and road network, medium scores (6-8) to areas with agriculture, pastures and forest plantations, lower scores (4) to degraded forests and mixed areas where natural vegetation is combined with crops, and the 
minimum score (0) to natural vegetation cover and other natural covers like rivers and lakes.

\subsubsection{Human access}

A cost surface layer was elaborated based on digital elevation models (DEM) to identify human access from the major and minor roads as well as navigable rivers. The COSTGROW module from Terrset (Eastman, 2015) was used considering the distance equivalent to what a person can walk around in a day $(\approx 25 \mathrm{~km})$.

The final map of human access was scored considering only three values: the minimum score (0) to the places outside of the area of influence of a road or a navigable river; a lower score (4) to the area nearby the roads or navigable rivers (surface within $25 \mathrm{~km}$ approximately), and a maximum score (10) to the communications network of major and minor roads as well as navigable rivers.

\subsubsection{Power infrastructure}

To incorporate energy development, we used the night images available by NOAA which were generated from satellite images. These images provide brightness values of visible average, stable lights and cloud coverages free annual series since 1992. Considering that our target periods are 1982, 1990 and 2008, we found just a coincidence (2008). To overtake this issue, we performed a regression between the images of 1992 and 2008 within the target area to generate images for 1982 and 1990 (F: 9.819e+05, p: < 2.2e-16 where significance $\left.\mathrm{p}<0.0001, R^{2}: 79.78 \%\right)$. Then, coefficients were applied to the periods that images were not available (1982 and 1990). Resulting maps were scored as 10 to areas with lights visible more than $89 \%$ of nights, as 8 to areas with lights visible between $40 \%$ to $88 \%$ of nights, as 4 to areas with lights visible less than $40 \%$ of nights, and 0 to areas where no lights were visible (Sanderson et al., 2002). 


\section{CHAPTER 4}

\section{Is alpha diversity enough to prioritize}

areas for conservation in Tropical regions?

- A case study in Continental Ecuador

\section{María Fernanda Tapia-Armijos ${ }^{1,2}$, Jürgen Homeier ${ }^{2}$, Carlos Iván Espinosa $^{1}$, Carmen Ulloa-Ulloa ${ }^{3}$, Zhofre Aguirre ${ }^{4}$, Marcelino De la Cruz ${ }^{5}$, Cristoph Leuschner ${ }^{2}$, David Draper Munt ${ }^{1,6}$}

${ }^{1}$ Sección de Ecología y Sistemática, Departamento de Ciencias Naturales, Universidad Técnica Particular de Loja, Loja, Ecuador,

${ }^{2}$ Plant Ecology, Albrecht von Haller Institute for Plant Sciences, University of Göttingen, Göttingen, Germany,

${ }^{3}$ Missouri Botanical Garden, St. Louis, USA.

${ }^{4}$ Universidad Nacional de Loja, Loja, Ecuador.

5 Área de Biodiversidad y Conservación, Departamento de Biología y Geología, ESCET, Universidad Rey Juan Carlos, Madrid, Spain.

${ }^{6}$ Centro de Ecologia, Evolução e Alterações Ambientais (CE3C - Centre for Ecology, Evolution and Environmental Changes), C2, Campo Grande, 1749-016, Portugal. 


\section{Is alpha diversity enough to prioritize areas for conservation in Tropical regions? - A case study in Continental Ecuador}

\subsection{Abstract}

In situ protection is certainly the best strategy to avoid the loss of the outstanding biodiversity of tropical forests. A well- designed reserve network is needed to maximize the representation of biodiversity in the protected areas. Usually, alpha diversity has been used as the preferred indicator to delimitate areas with high potential for conservation. However, in countries with high environmental heterogeneity, it may be necessary to consider beta diversity as well. In this study, we model the potential distribution of 3988 endemic plant species in order to 1) evaluate the patterns of alpha and beta diversity in continental Ecuador, 2) identify the areas with the highest potential alpha and beta diversity, 3) understand the spatial correlation between both diversity indicators, and 4) identify gaps in the conservation of endemic plant species in order to define priority areas of conservation that complement the existing reserve network. We found that alpha diversity hotspots of endemic plant species are concentrated in the Andes unlike hotspots of beta diversity which are more concentrated in the western and eastern escarpments of the Andes and the Coastal and Amazon Cordilleras. Only about $30 \%$ of the areas with the highest alpha or beta diversity are overlapping which means that the use of only alpha diversity for selecting areas of highest conservation priority may lead to underrepresentation of a large proportion of the total plant diversity of a region. We also found that approximately $40 \%$ of the areas with the highest alpha and also beta diversity in Ecuador have already disappeared due to deforestation and that only $30 \%$ of the remaining areas with high alpha and beta diversity are under protection. With our approach, we identified important gaps in the conservation system and accordingly propose 12 potential conservation areas of highest priority which are mostly located in South Ecuador. This study represents the first step towards a better understanding of the spatial patterns of beta diversity of endemic plant species and, it highlights the importance of considering this biodiversity component as a valuable additional indicator to be included in strategic conservation planning. 


\subsection{Introduction}

Tropical forests have been recognized as centers of high biological diversity and endemism (Gentry, 1992; Gaston, 2000, Myers et al., 2000) but they are highly threatened by rapid conversion and degradation (Myers, 1988; Laurance, 1999, Dirzo and Peter, 2003). This dilemma has resulted in the metaphor of the "tropical biodiversity crisis" (Laurance, 2006; Vamosi and Vamosi, 2008) to describe how the loss and degradation of tropical habitats have caused the extremely high rates of species extinction observed in the last decades (Wilson, 1988; Brooks et al., 2002; Pin Koh et al., 2004; Bradshaw et al., 2006).

In situ conservation is the most important strategy to conserve tropical biodiversity (Naughton - Treves et al., 2005). Protected areas have as ultimate goals to safeguard biodiversity from processes that threaten its persistence and to include a portion of every biodiversity feature (Margules and Pressey, 2000; Margules et al., 2002; Gaston et al., 2002; Wilson et al., 2009).

Although the first goal has been largely achieved at least within protected areas (Bruner et al., 2001; Nagendra, 2008; Gaveau et al., 2009; Geldmann et al., 2013), the second has been more elusive, especially in the tropics. On one side, many protected areas are the result of ad hoc approaches (Pressey, 1994; Scott et al., 2001; Rodriguez et al., 2004) and therefore these have been placed in remote, inaccessible or unproductive lands with sometimes relatively low biological value (Pressey et al., 1996; Margules and Pressey, 2000). On the other hand, the often poor knowledge about biodiversity, the total number of species and its distribution (Whittaker et al., 2005), is the reason that the vast majority of protected areas worldwide are inadequately representing the original biodiversity (Scott et al., 2001; Armenteras et al., 2003; De Klerk et al., 2004; Fjeldsa et al., 2004; Maiorano et al., 2006; Cantú-Salazar et al., 2012; Brugière and Scholte, 2013; Rubio-Salcedo et al., 2013). As an example, Rodriguez et al. (2004) mentioned that taxa with high levels of endemism and restricted ranges have higher probabilities to be less represented in global reserve networks.

More recently, some conservation planning approaches have been developed to address these limitations (Margules and Pressey; 2000; Groves et al., 2002; Margules et al., 2002; 
Cowling and Pressey, 2003; Sarkar and Illoldi-Rangel, 2010). These approaches seek to maximize the representation of biodiversity proposing new areas that must be incorporated into the current reserve network based on diversity patterns of selected biodiversity surrogates (Ferrier, 2002; Pressey, 2004).

The traditional practice has been to prioritize areas for conservation based on high levels of alpha diversity or species richness (e.g. Mittermeier et al., 1998; Myers et al., 2000).

Nevertheless, alpha diversity is just one of the biodiversity components in a region (Whittaker, 1972) and using it as the only biodiversity indicator may cause a misleading selection of priority areas for conservation, especially in areas with high environmental heterogeneity (Pimm and Gittleman; 1992; Ferrier, 2002; McKnight et al., 2007, Melo et al., 2009). In such areas the variation in species composition among sites, termed beta diversity, may be a better biodiversity indicator. Consequently, areas that include the most different taxa should have a higher priority for conservation than those containing more similar taxa (Pimm and Gittleman; 1992; Whittaker, 1972; Anderson et al., 2011).

According to Tylianakis et al. (2005) and Kessler et al. (2005), alpha and beta diversity may show different spatial patterns. However, there is high congruence between beta diversity patterns of different taxa (Kessler et al., 2005) especially in the Neotropics (Mcknight et al., 2007). Beta diversity is probably a good indicator to increase the representativeness and complementarity of the current protected areas network. However, this does not mean that the identification of hotspots based on alpha diversity is not useful to prioritize conservation areas, it just means that the combined use of both biodiversity indicators will improve the results. While alpha diversity has allowed establishing large areas with high importance for conservation, it is beta diversity which allows locating smaller and particular areas, ensuring an optimal configuration (e.g. number and distribution) of conservation networks (Kattan et al., 2006; McKnight et al., 2007).

Despite the importance of using alpha and beta components together as indicators of biodiversity in systematic conservation planning, few studies have used both components to identify conservation gaps and prioritize new areas for conservation. In this context, this 
study characterizes the spatial patterns of alpha and beta diversity of endemic plant species in Ecuador to evaluate conservation gaps in order to prioritize areas for conservation.

Two recent approaches prioritized conservation areas for Ecuador based on alpha diversity (Mateo et al., 2013; Lessmann et al., 2014). These studies have shown a particularly high importance for conservation in the northern Amazon and in the northern coast region while the Andean region was identified as being of secondary importance, based on a combination of 809 well-studied terrestrial species of amphibians, bird, mammals and plants (Lessmann et al. 2014) or on using an ensemble approach with 408 plant species (Mateo et al. 2013). We contrast these studies with our model data on the distribution of all endemic plant species (3988), and we add the component of beta diversity.

\subsection{Methods}

\subsubsection{Study area}

The study area comprises the continental part of Ecuador (Figure 4.1) with a total surface area of $248,313 \mathrm{~km}^{2}$. Ecuador has been recognized as one of the most biodiverse countries on the earth (Jørgensen et al., 1992; Sierra et al., 2002) harboring 17,748 species of vascular plants (Neill, 2012) and more than 2000 vertebrate species. The presence of the Andes mountain range, which crossed Ecuador from north to south, divides the country into three major biogeographic regions (Coastal, Andean and Amazon regions). The coastal region, located west of the Andes, is part of the Tumbes-Chocó-Magdalena biodiversity hotspot which has been recognized for its high levels of endemism (Davis et al., 1997; Linares-Palomino, 2005; Linares-Palomino et al., 2010). The Andean region is part of the Tropical Andes biodiversity hotspot recognized as one of the five global centers of vascular plants diversity with more than 5000 species per 10,000 km² (Barthlott et al., 2007). The last region, the Amazon region, is part of the Amazon lowlands where high levels of tree diversity per unit ground area have been observed (Gentry, 1992; Ter Steege et al., 2000, Valencia et al., 2004). 


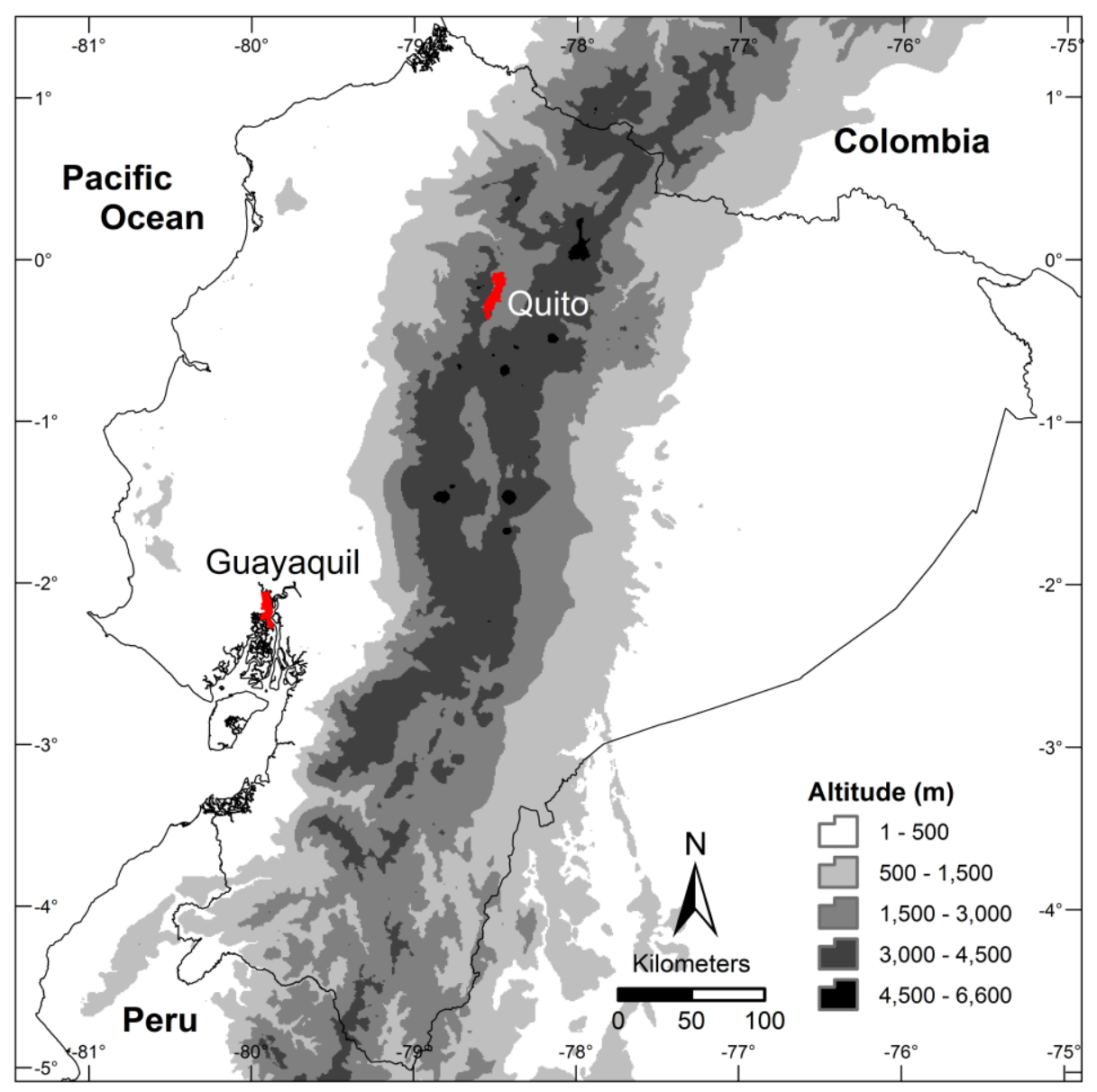

Figure 4.1 Map of continental Ecuador and its altitudinal zones.

\subsubsection{Selection of biodiversity surrogates}

The use of biodiversity surrogates is a common practice to guide the identification of potential reserves in areas with poor knowledge about biodiversity (Caro et al., 1999; Margules et al., 2002). In this study, we use as biodiversity surrogate the plant species endemic to Ecuador according to the last update of the Red List (León-Yánez et al., 2011). A total of 3988 species were selected after excluding all endemics of the Galapagos Islands. We choose plant taxa because these determine important ecosystem processes and they support other life forms (Loreau et al., 2001; Kremen, 2005; Mateo et al., 2013). We choose endemic plant species because 1) these represent approximately $25 \%$ of the Ecuadorian flora (León-Yánez et al., 2011; Neill, 2012), 2) endemic species usually have narrow distributions and small populations which make them more vulnerable to the threat 
of extinction (Gaston, 1998; Kouki et al., 2001; Myers et al., 2000), 3) endemic taxa often exhibit distribution patterns with close correlation to environmental heterogeneity (Lamoreux et al., 2006) and 4) priority conservation networks based on endemic species contain large numbers of species, which suggests the suitability of this group as a biodiversity surrogate (Lamoreux et al., 2006).

\subsubsection{Ecological niche modeling}

Rodrigues and Brooks (2007) suggest that the use of biodiversity surrogates to prioritize areas for conservation is more effective when extrapolated data are used instead of field data. To obtain the potential geographic distribution we generated ecological niche models for each species (ENMs).

Occurrence data of 3988 continental Ecuadorian endemic species were obtained from the TROPICOS database (Missouri Botanical Garden) and the GBIF (Global Biodiversity Facility - www.gbif.org/) database. Random pseudo-presences were generated within a five kilometers buffer radius when species had less than five known populations until reaching a minimum number of five locations per species. ENMs were generated using the Maxent algorithm v. 3.3.3e (Phillips et al. 2006), which estimates a target probability distribution by finding the probability distribution of maximum entropy subjects to a set of constraints that represent the incomplete information about the target distribution. This algorithm is appropriate for presence-only data and has been considered to generate the best output comparing different models (Elith et al. 2006; Ortega-Huerta \& Peterson 2008). GIS layers used in the ENM include the 19 climate data variables from Worldclim (Hijmans et al. 2005, http://www.worldclim.org/) with a 30 arc-second resolution (approximately $1 \mathrm{~km}^{2}$ ) and the altitude obtained from SRMT (http://srtm.csi.cgiar.org/). Slope inclination and aspect were also derived from the altitude layer. All variables were adjusted to a spatial resolution of 30 arc-seconds.

The background area considered for each species was the area within the minimum convex polygon (MCP) plus a buffer of $200 \mathrm{~km}$, following VanDerWal et al. (2009). Variable selection was carried out in two steps: 1) correlation analyses between the variables were performed, and high correlation was assumed if $\mathrm{R}$ was $\geq 0.75$ (Pearson coefficient); we 
retained the variable considered to be the most biologically relevant for subsequent modeling when this occurred; 2) the predictive power of environmental variables was assessed using the Maxent jackknife measure to test the Area Under the Curve (AUC) of a receiver-operating characteristic (ROC) plot. Variables with low AUC contribution $\leq 0.5$ were removed and those remaining were used for the final model (Bellamy et al. 2013). Five model replicates were run for each one of the presence-only methods using the $75 \%$ of occurrences for calibration and different sub-sets $(25 \%)$ for validation. The mean of the AUC was used to assess the performance of the models (Zweig \& Campbell 1993; Greaves et al. 2006; Milne et al. 2006), where 1 is the maximum prediction and 0.5 suggests a random prediction.

To obtain a binary map, the threshold of the resulting models was determined as the minimum predicted value (MPV) that included all records of each species so that a $0 \%$ omission error (proportion of observed presences incorrectly predicted) was attained (Sérgio et al. 2007). The resulting maps illustrate the minimal predicted area (MPA) predicted for $100 \%$ of the presences (Guisan et al. 2006; Jiménez-Alfaro et al. 2012). By assigning a $0 \%$ omission error, we enforced that all known populations were included in the predicted area. Idrisi Selva 17.01 (Clark Labs, Clark University) was used to prepare GIS layers, and Maxent to analyze the results.

\subsubsection{Alpha and beta diversity patterns}

In this study, we used as biodiversity indicators the alpha $(\alpha)$ and beta $\left(\beta_{\mathrm{dis}}\right)$ components. We considered alpha diversity as the richness of species at each location (pixel of $1 \mathrm{~km}^{2}$ ) resulting from adding the binary maps of all single species. Since there are several definitions of beta diversity (Anderson et al., 2011), in this study we defined beta diversity as the variability in species composition among sampling units for a given area (Anderson et al., 2006). To calculate beta diversity we used Soerensen's dissimilarity index (1 minus Sorensen's Index) which is computed as the number of species that are common between each pixel and the region to which it belongs divided by the average alpha diversity of the respective region (Whittaker, 1972), here the region included in a moving-window with a focal diameter of $10 \mathrm{~km}$ around each pixel. We selected a $10 \mathrm{~km}$ distance arguing that 1) in landscapes with major dispersal barriers, community similarity decreases abruptly 
(Garcillán and Ezcurra, 2003) and b) less mobile species show high dissimilarity at short distances (Kessler et al., 2005). Both analyses were developed using the Habitat and Biodiversity Modeler module available in the Terrset Geospatial and Monitoring System (Clark Labs, Clark University). Terrset Geospatial and Monitoring System (Clark Labs, Clark University).

\subsubsection{Analysis of alpha and beta patterns of biodiversity}

Once maps of alpha and beta diversity were obtained for continental Ecuador, they were reclassified into quartiles. Following the methodology proposed by Mateo et al., (2013), we selected the upper quartile as the areas with the highest values of alpha and beta diversity. The spatial overlap between richest areas of alpha and beta diversity was calculated as well as the areas where alpha and beta diversity were highest.

\subsubsection{Identification of conservation gaps and priority conservation areas}

We use the map of vegetation for continental Ecuador (MAE, 2013) to evaluate the remaining area of each of three detected areas (high alpha and beta diversity overlapping, high alpha diversity and high beta diversity). Additionally, we compared the remaining areas with the protected areas that belong to the PANE system to find out how much land area is protected by each detected area and to delimitate the areas that could be included as new areas for conservation. We choose as the first priority of conservation those areas where alpha and beta diversity overlap, as a second priority the areas with the highest beta diversity and as a third priority the areas with highest alpha diversity.

\subsection{Results}

\subsubsection{Alpha diversity patterns}

The highest potential alpha diversity of endemic plant species is concentrated along the Andes in their north-south extension in Ecuador (Figure 4.2A) and is decreasing toward the eastern and western foothills and lowlands. An exception is South Ecuador, where high alpha diversity levels also are observed west and east of the Andes. The areas with the 
lowest values of potential alpha diversity are those located in the coastal and Amazonian

lowlands of central and northern Ecuador. Much of the areas with the highest levels of potential alpha diversity have already disappeared as a consequence of natural habitat conversion (Figure 4.2B). Important areas remain on the eastern Andean escarpments under protection, especially those located in the northern and central foothills in the Cayambe Coca Ecological Reserve and the Llanganates, Sangay, Podocarpus and Yacuri National Parks. On the western slope, most areas with high potential alpha diversity have disappeared with exception of those located in southern Ecuador and between the Illinizas and Cotocachi-Cayapas Ecological Reserves, where the major part of the area is not protected.

\subsubsection{Beta diversity patterns}

The areas with the highest potential beta diversity are located in the eastern and western escarpments of the Andean range, in the humid forests of the Cordillera Cóndor-Kutukú and Pastaza and the dry and humid forests of the coastal cordillera proximate to Jipijapa (Figure 4.2C). The lowest scores are found in the humid coastal and Amazonian lowlands. Almost all the areas with highest levels of potential beta diversity located on the western slope of the Andes have disappeared (Figure 4.2D). Important remnant areas that are still not protected are located in the Cordillera Cóndor-Kutukú, in the seasonally dry ecosystems of South Ecuador and the dry forests of the Central Coast region. 

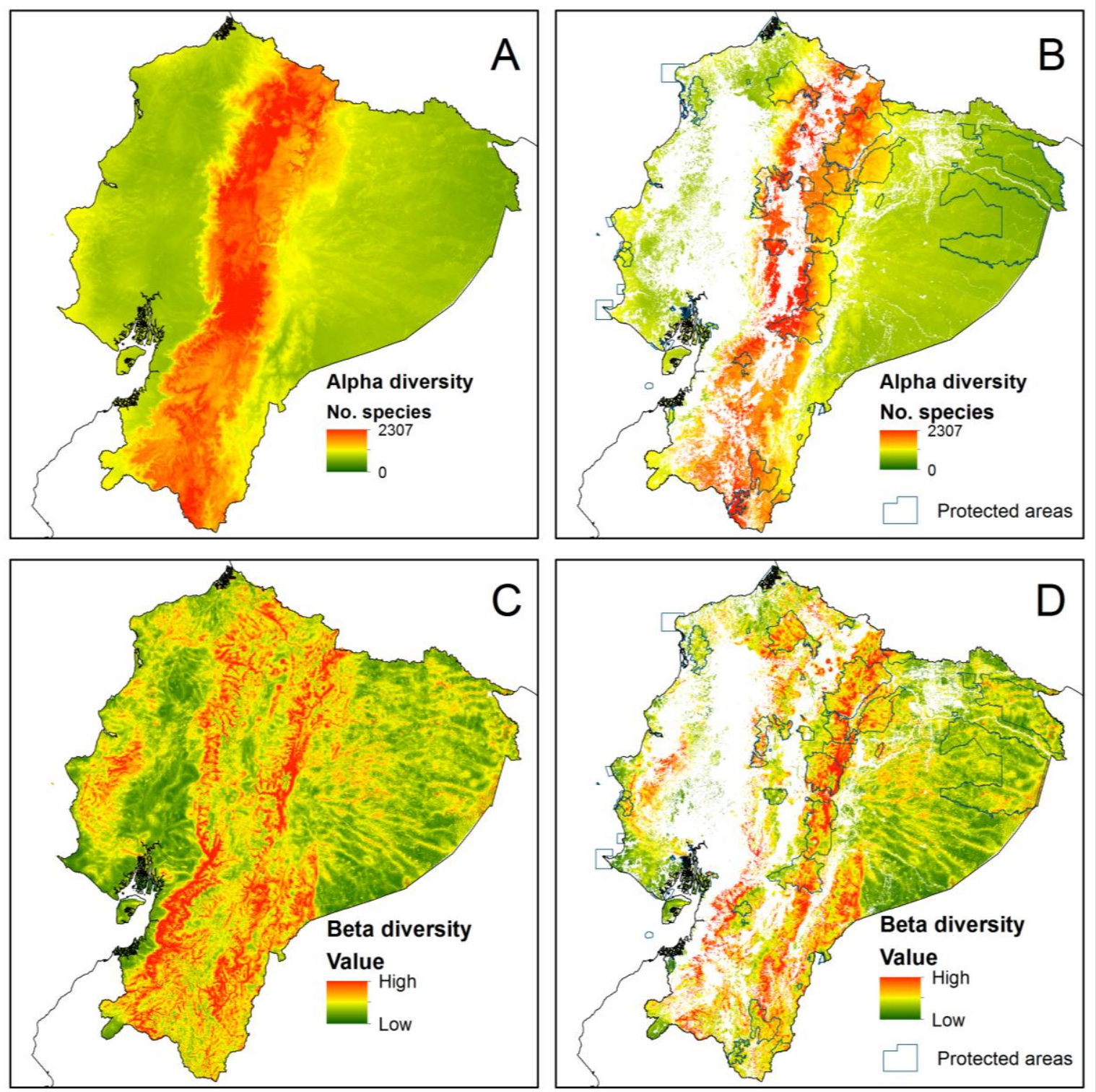

Figure 4.2 A. Potential alpha diversity map for continental Ecuador; B. Remaining areas of potential alpha diversity and location of protected areas (PANE: Patrimonio de Áreas Naturales del Estado); C. Potential beta diversity map for continental Ecuador; D. Remaining areas of potential beta diversity and location of PANE.

\subsubsection{Congruence of patterns of alpha and beta diversity}

Comparing the areas with the highest potential levels of alpha and beta diversity (Figure

4.3) we find that $39 \%$ of the areas with highest alpha diversity overlap with areas of highest 
beta diversity and that $36 \%$ of the areas with highest beta diversity overlap with areas of highest alpha diversity. The areas where high alpha and beta diversity overlap are mostly located at the higher altitudes (> $1000 \mathrm{~m}$ a.s.1.) of the Andean range. The largest areas are found on the eastern and western slopes of the central-southern Andes section. There is no overlap in the patterns of high alpha and beta diversity areas in the coastal and Amazonian lowlands; only beta diversity reaches high levels in these areas.

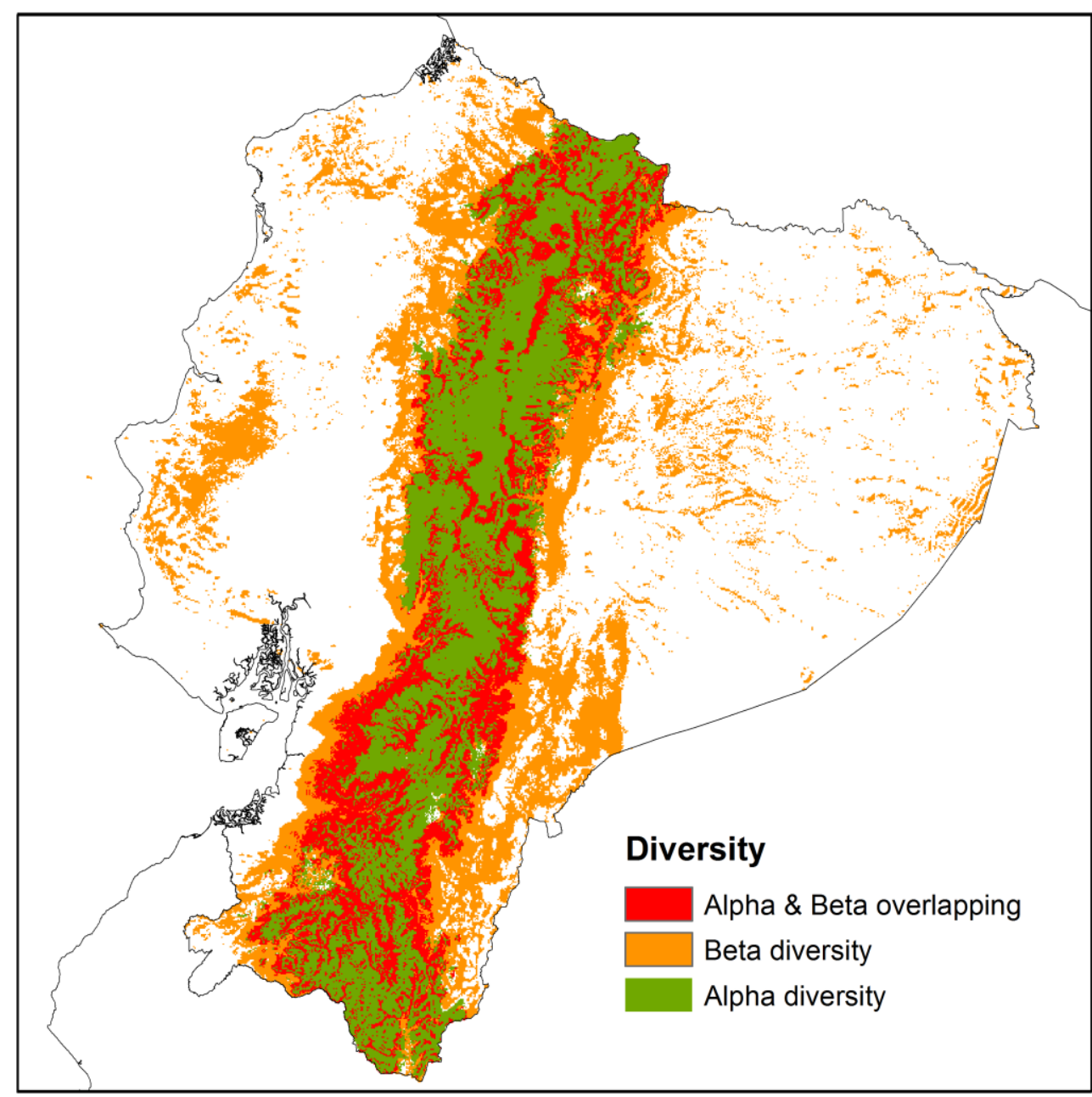

Figure 4.3 Map showing the areas of high alpha and beta diversity and the overlap of both areas. 


\subsubsection{Identification of conservation gaps and potential areas for conservation}

Of the total area with potentially highest alpha and beta diversity, approximately $37 \%$ has already disappeared which means that a good proportion remains conserved or has the potential to be conserved (Table 4.1). Our analyses also show that only $31 \%$ of the area where high alpha and beta diversity overlap is under protection. A similar share is observed for the remaining areas of high alpha or beta diversity which are conserved in $30 \%$ of its area (Table 4.2; Figure 4.4). From the different protection categories of the PANE, the National Parks are those which protect the major surface of alpha and beta richest areas, followed by the Ecological reserves (Table 4.2). Wildlife refuges have the lowest area which is explained by the fact that its principal function is to conserve animal taxa.

Table 4.1 Extent of potential high-diversity areas, remaining potential protection areas and proportion of currently protected areas.

\begin{tabular}{lccccc}
\hline \hline & Potential Area & \multicolumn{2}{c}{ Remaining Area } & \multicolumn{2}{c}{ Protected Area (PANE) } \\
& $\mathbf{k m}^{\mathbf{2}}$ & $\mathbf{k m}^{\mathbf{2}}$ & $\mathbf{\%}$ & $\mathbf{k m}^{\mathbf{2}}$ & $\mathbf{\%}$ \\
\hline \hline Alpha/Beta overlapping & 23,400 & 14,680 & 63 & 4612 & 31 \\
Alpha diversity & 38,148 & 21,461 & 56 & 6500 & 30 \\
Beta diversity & 41,939 & 26,677 & 67 & 7984 & 30 \\
\hline \hline
\end{tabular}

In this study, we have identified areas with conservation gaps and therefore with potential for conservation (Figure 4.4). Additionally, we have established three different priority levels of conservation based on the diversity patterns that characterize these areas. As areas with the highest priority for conservation have been identified 1) the páramo and forest areas located in the surroundings of the Cajas National Park, 2) the humid forests of the eastern escarpments between Podocarpus and Sangay National Parks, 3) the remaining shrublands of the humid and dry interandean valleys in Loja Province, 4) the semideciduous forests of Catamayo-Alamor, 5) the western Andean escarpments between the Ecological Reserves Los Illinizas and Cotacachi-Cayapas and 6) the surroundings of the Ecological Reserve El Ángel. We determined as areas of second-highest priority of 
conservation 7) the remaining forests in the surroundings of the Machalilla National Park, 8) the humid forests in the mountain and foothill areas of the Cordillera Cóndor-Kutukú, 9) the humid forests in the western escarpments of the Andes in the area bordering with Colombia, and 10) the floodplain forests in the Amazonian Cordillera escarpments. Finally, we identify as the third priority of conservation 11) the páramo areas in the influence area of the Cotopaxi reserve and 12) the montane forest and páramo areas in the border area of Saraguro, Nabón, and Yacuambi.

Table 4.2 Extent of diversity categories under the different conservation categories in the PANE.

\begin{tabular}{lccc}
\hline \hline & $\begin{array}{c}\text { Alpha-beta overlapping } \\
\left(\mathbf{k m}^{\mathbf{2}}\right)\end{array}$ & $\begin{array}{c}\text { Alpha diversity } \\
\left(\mathbf{k m}^{\mathbf{2}}\right)\end{array}$ & $\begin{array}{c}\text { Beta diversity } \\
\left(\mathbf{k m}^{\mathbf{2}}\right)\end{array}$ \\
\hline \hline National Recreation Areas & 1.4 & 32.0 & 0.0 \\
Wildlife Reserve Production & 28.6 & 447.9 & 480.6 \\
Geobotanical Reserves & 13.1 & 16.1 & 0.0 \\
Ecological Reserves & 860.0 & $1,057.6$ & $1,350.0$ \\
Biological Reserves & 73.0 & 295.0 & 749.9 \\
Wildlife Refuges & 3.0 & 2.0 & 5.1 \\
National Parks & $3,633.3$ & $4,649.8$ & $4,661.7$ \\
\hline \hline
\end{tabular}




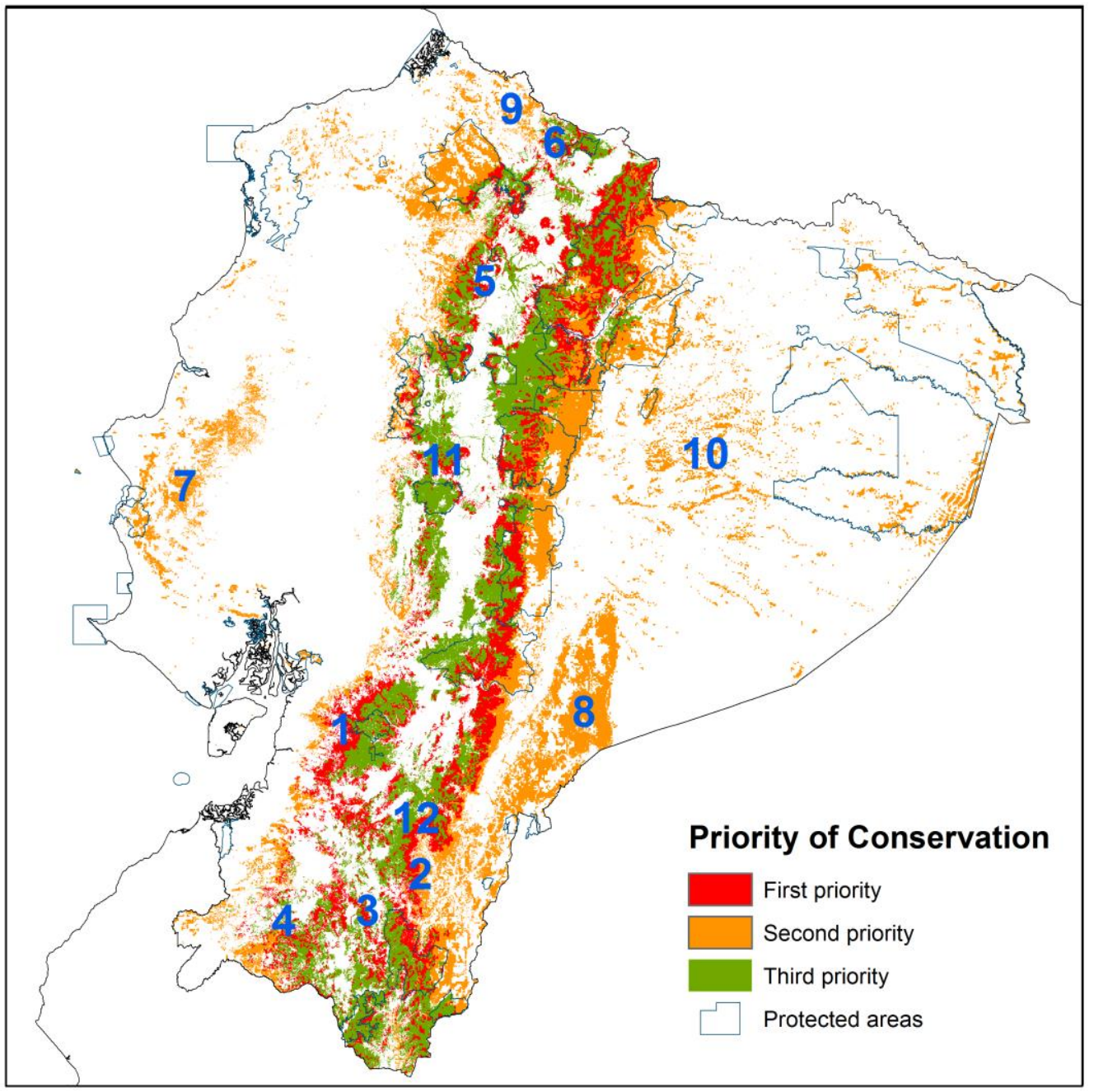

Figure 4.4 Location of potential areas of conservation in continental Ecuador with three different levels of conservation priority. Level 1: 1. Páramo and forest areas located in the influence area of the Cajas National Park, 2. the humid forests of the eastern escarpments between Podocarpus and Sangay National Parks, 3. interandean valleys in Loja Province, 4. the semi-deciduous forests of Catamayo-Alamor, 5. the western Andean escarpments between the Ecological Reserves Los Illinizas and Cotacachi-Cayapas and 6. the influence area of the Ecological Reserve El Ángel. Level 2: 7. influence area of the Machalilla National Park, 8. mountain and foothill areas of the Cordillera Cóndor-Kutukú, 9. western escarpments of the Andes in the area bordering with Colombia, 10. the floodplain forests in the Amazonian Cordillera escarpments. Level 3: 11. páramo in the influence area of the Cotopaxi reserve and 12. the montane forest and páramo areas in the border area of Saraguro, Nabón, and Yacuambi. 


\subsection{Discussion}

\subsubsection{Underlying causes of the observed alpha and beta diversity patterns}

Decide what and where to conserve is a difficult but essential task to ensure the persistence of biodiversity, especially in areas with outstanding biodiversity like continental Ecuador. Thus, understanding biodiversity patterns in the context of conservation planning is essential to guide decision making.

The study of the potential alpha and beta diversity patterns of endemic vascular plant species showed the richest areas to be concentrated in the Andes and its western and eastern escarpments. The Ecuadorian Andes are part of the Tropical Andes hotspot where locally endemic plants represent $6.4 \%$ of the world plant species (Myers, 2000). There are several reasons for the high species concentration in these areas. Cowling and Samway (1995) mention a positive correlation between the richness of endemic plants and low latitudes. However, high levels of beta diversity are found across a wide range of latitudes and seem to be more related to medium and higher elevations, rough topography and biome boundaries (McKnight et al., 2007). In mountain areas, large differences in altitude and temperature occur over short distances producing rapid species turnover as a result of the high niche complexity (Melo et al., 2009).

While highest levels of alpha diversity of endemic plant species were exclusively concentrated in the Andes and its escarpments, highest levels of beta diversity were also observed in the Coastal regions and the Amazonian cordilleras. The last exhibit lower altitudes than the Andes but also have an irregular topography. In the case of the coastal lowlands, high beta diversity levels seem to be related to the spatial isolation of dry forest areas (Best and Kessler, 1995; Gentry, 1995).

In contrast to alpha diversity patterns, beta diversity patterns are scale-dependent (Mcknight

et al., 2007; Mandl et al., 2010). Since our goal was to provide useful information for conservation planning, we chose a focal distance of $10 \mathrm{~km}$ to evaluate variation in species composition following the recommendations of Kattan et al. (2006). These authors 
mentioned that the optimal configuration of conservation networks should be the result of fine-scale beta diversity patterns.

\subsubsection{Observed diversity patterns compared to other studies}

Our study is not the first to look for potential conservation areas based on alpha diversity patterns or biodiversity surrogates for Ecuador (Sierra et al., 2002; Peralvo et al., 2006; Mateo et al., 2013; Lessmann et al., 2014), but it is the first that used beta diversity patterns as a complementary indicator. Since different approaches have been used it could be expected that the results differ. Particular differences have been found between our results and the two more recent approaches (Mateo et al., 2013; Lessmann et al., 2014), which identified areas of high conservation need at the northern coast and in the Amazon.

In our study, we have identified that although there are some important areas of alpha and beta diversity without protection in central and north Ecuador, the vast majority of unprotected areas with high conservation potential is located in South Ecuador. Here, there are areas with high alpha and beta diversity overlapping but also important areas that have been recognized for its unique species composition (e.g. Cordillera del Cóndor-Kutukú) (Neill, 2005; Almendáriz et al., 2014).

The differences between the cited recent approaches and our study may be related to factors. On the one hand, the biodiversity surrogates used were different. Mateo et al. (2013) used 408 plant species with well-known distributions with a small proportion of endemic species, Lessmann et al. (2014) used vertebrate species (303 species) and also plants (506 species). Although there is congruence in the alpha diversity patterns of different taxa (Myers et al., 2000), there is no congruence between hotspots of species richness and areas of endemism (Orme et al., 2005).

On the other hand, low congruence between alpha and beta diversity has been demonstrated by various authors (Kessler et al., 2005; Tuomisto and Ruokolainen, 2005; Barlow, 2007). In our study, we show that only $30 \%$ of the areas with the highest alpha or beta diversity are overlapping, so the exclusive use of alpha diversity as biodiversity indicator in the 
studies of Mateo et al. (2013) and Lessmann et al. (2014) leads to in the identification of different areas important for conservation.

Rodrigues and Brooks (2007) suggest that for maximizing the effectiveness of biodiversity surrogates, it is recommended to use extrapolated data instead of the original field data. Thus, the use of species distribution models has increased in conservation prioritization (Elith and Leathwick; 2009). To reduce the error, it is recommended to avoid the use of poorly documented species. However, in highly diverse areas a high proportion of species with few known occurrences is common. In this study, we attempted to adjust the modeling technique to use the complete number of endemic plant species for achieving a better representation of the total diversity of these taxa. Despite the differences detected between the different approaches, their combination is useful to improve conservation planning in Ecuador.

\subsubsection{Potential conservation areas in the context of conservation planning}

Three main principles of systematic conservation planning are the comprehensiveness, representativeness, and complementarity of protected areas (Wilson et al., 2009). We believe that the combined use of alpha and beta diversity patterns as indicators to select new areas for conservation provides a good approximation to achieve these principles. To reach this goal, we propose as the first priority of conservation those areas where highest levels of alpha and beta diversity overlap because it guarantees not only a great number of species to be conserved but also covers a gradient of endemic plant species with the representation of different floras in the conservation area. The second priority is based on the areas with highest levels of beta diversity patterns. According to Gaston (1996), the potential value of an area is more dependent on which species occur there rather than on the pure number of species. Consequently, as the third priority for conservation, we selected those areas with exclusively high alpha diversity.

Several gaps in the conservation system have been identified, especially in the western escarpments of the Andes and in the remaining forests of South Ecuador. Both regions are characterized by high levels of deforestation and fragmentation (Dodson and Gentry, 1991; Wunder, 2000, Tapia et al., 2015). 


\subsection{Conclusions}

Our approach allows a better understanding of the patterns of alpha and beta diversity of endemic plant species in Ecuador. However, although this is a first step to locating new reserves that ensure adequate representativeness and complementarity, additional information (e.g. landscape integrity, vulnerability) should be considered in order to ensure the long-term persistence of the proposed reserves. Finally, we strongly suggest that information on beta diversity patterns should be included in the process of area prioritization. To omit this information can lead to the protection of areas that are rich in species but that do not consider unique or rare species adequately.

\subsection{Acknowledgments}

We want to M.C. Ruíz, D. Salcedo and J.M. Arteaga for their technical support and C. Iñiguez-Armijos for his commentaries about the figures. This research was financially supported by the SENESCYT scholarship program 2010 and the DFG within the research unit FOR 816 (project HO 3296/2).

\subsection{References}

Almendáriz, A., Simmons, J. E., Brito, J., \& Vaca-Guerrero, J. (2014). Overview of the herpetofauna of the unexplored Cordillera del Cóndor of Ecuador. Amphibian \& Reptile Conservation, 8(1), 45-64.

Anderson, M. J., Crist, T. O., Chase, J. M., Vellend, M., Inouye, B. D., Freestone, A. L., \& Swenson, N. G. (2011). Navigating the multiple meanings of $\beta$ diversity: a roadmap for the practicing ecologist. Ecology Letters, 14(1), 19-28.

Anderson, M. J., Ellingsen, K. E., \& McArdle, B. H. (2006). Multivariate dispersion as a measure of beta diversity. Ecology Letters, 9(6), 683-693. 
Armenteras, D., Gast, F., \& Villareal, H. (2003). Andean forest fragmentation and the representativeness of protected natural areas in the eastern Andes, Colombia. Biological Conservation, 113(2), 245-256.

Barthlott, W., Hostert, A., Kier, G., Küper, W., Kreft, H., Mutke, J., \& Sommer, J. H. (2007). Geographic patterns of vascular plant diversity at continental to global scales. Erdkunde, 61(4), 305-315.

Bellamy, C., C. Scott, and J. Altringham. (2013). Multiscale, presence-only habitat suitability models: fine-resolution maps for eight bat species. Juornal of Applied Ecology, 50, 892-901.

Best, B., \& Kessler, M. (1995). Biodiversity and conservation in Tumbesian Ecuador and Peru (Vol. 218). Cambridge, England: BirdLife International.

Brooks, T. M., Mittermeier, R. A., Mittermeier, C. G., Da Fonseca, G. A., Rylands, A. B., Konstant, W. R., \& Hilton-Taylor, C. (2002). Habitat loss and extinction in the hotspots of biodiversity. Conservation Biology, 16(4), 909-923.

Brugière, D., \& Scholte, P. (2013). Biodiversity gap analysis of the protected area system in poorly-documented Chad. Journal for Nature Conservation, 21(5), 286-293.

Bruner, A. G., Gullison, R. E., Rice, R. E., \& Da Fonseca, G. A. (2001). Effectiveness of parks in protecting tropical biodiversity. Science, 291(5501), 125-128.

Cantú-Salazar, L., Orme, C. D. L., Rasmussen, P. C., Blackburn, T. M., \& Gaston, K. J. (2013). The performance of the global protected area system in capturing vertebrate geographic ranges. Biodiversity and Conservation, 22(4), 1033-1047.

Caro, T. M., \& O'Doherty, G. (1999). On the use of surrogate species in conservation biology. Conservation Biology, 13(4), 805-814.

Cowling, R. M., \& Pressey, R. L. (2003). Introduction to systematic conservation planning in the Cape Floristic Region. Biological Conservation, 112(1), 1-13. 
Cowling, R. M., \& Samways, M. J. (1995). Endemism and biodiversity. Global Biodiversity Assessment. Cambridge, 174-191.

Dirzo, R., \& Raven, P. H. (2003). Global state of biodiversity and loss. Annual Review of Environment \& Resources, 28(1), 137-167.

Dodson, C. H., \& Gentry, A. H. (1991). Biological extinction in western Ecuador. Annals of the Missouri Botanical Garden, 78(2), 273-295.

Elith, J., \& Leathwick, J. (2009). The contribution of species distribution modelling to conservation prioritization. In: Moilanen, A., Wilson, K. A., Possingham, H. P.,editors. Spatial conservation prioritization quantitative methods and computational tools. Oxford University Press Oxford, pp. 70-93. Oxford.

Elith, J., Graham, C.H., Anderson, R.P., Dudík, M., Ferrier, S., Guisan, A., Hijmans, R.J., et al. (2006). Novel methods improve prediction of species' distributions from occurrence data. Ecography, 29,129-151.

Ferrier, S. (2002). Mapping spatial pattern in biodiversity for regional conservation planning: where to from here? Systematic Biology, 51(2), 331-363.

Fjeldså, J., Burgess, N. D., Blyth, S., \& De Klerk, H. M. (2004). Where are the major gaps in the reserve network for Africa's mammals? Oryx, 38(01), 17-25.

Garcillán, P. P., \& Ezcurra, E. (2003). Biogeographic regions and $\beta$-diversity of woody dryland legumes in the Baja California peninsula. Journal of Vegetation Science, 14(6), 859-868.

Gaston, K. J. (1996). Species-range-size distributions: patterns, mechanisms and implications. Trends in Ecology \& Evolution, 11(5), 197-201.

Gaston, K. J. (2000). Global patterns in biodiversity. Nature, 405(6783), 220-227.

Gaston, K. J., Blackburn, T. M., \& Spicer, J. I. (1998). Rapoport's rule: time for an epitaph? Trends in Ecology \& Evolution, 13(2), 70-74. 
Gaveau, D. L., Epting, J., Lyne, O., Linkie, M., Kumara, I., Kanninen, M., \& LeaderWilliams, N. (2009). Evaluating whether protected areas reduce tropical deforestation in Sumatra. Journal of Biogeography, 36(11), 2165-2175.

Geldmann, J., Barnes, M., Coad, L., Craigie, I. D., Hockings, M., \& Burgess, N. D. (2013). Effectiveness of terrestrial protected areas in reducing habitat loss and population declines. Biological Conservation, 161, 230-238.

Gentry, A. H. (1992). Tropical forest biodiversity: distributional patterns and their conservational significance. Oikos, 63, 19-28.

Greaves, R.K., Sanderson, R.A., Rushton, S.P. (2006). Predicting species occurrence using information-theoretic approaches and significance testing: An example of dormouse distribution in Cumbria, UK. Biological Conservation 130, 239-250.

Groves, C. R., Jensen, D. B., Valutis, L. L., Redford, K. H., Shaffer, M. L., Scott, J. M., \& Anderson, M. G. (2002). Planning for Biodiversity Conservation: Putting Conservation Science into Practice A seven-step framework for developing regional plans to conserve biological diversity, based upon principles of conservation biology and ecology, is being used extensively by the nature conservancy to identify priority areas for conservation. BioScience, 52(6), 499-512.

Guisan, A., Tingley, R., Baumgartner, J.B., Naujokaitis-Lewis, I., Sutcliffe, P.R., et al. (2006). Predicting species distributions for conservation decisions. Ecology Letters, 16, $1424-1435$.

Hijmans, R.J., Cameron, S.E., Parra, J.L., Jones, P.G., \& Jarvis, A. (2005). Very high resolution interpolated climate surfaces for global land areas. International Journal of Climatology, 25, 1965-1978.

Jiménez-Alfaro, B., Draper, D., \& Nogués-Bravo, D. (2012). Modeling the potential area of occupancy at fine resolution may reduce uncertainty in species range estimates. Biological Conservation, 147, 190-196. 
Kattan, G. H., Franco, P., Saavedra-Rodríguez, C. A., Valderrama, C., Rojas, V., Osorio, D., \& Martinez, J. (2006). Spatial components of bird diversity in the Andes of Colombia: implications for designing a regional reserve system. Conservation Biology, 20(4), 1203-1211.

Kessler, M., Abrahamczyk, S., Bos, M., Buchori, D., Putra, D. D., Gradstein, S. R., \& Tscharntke, T. (2009). Alpha and beta diversity of plants and animals along a tropical land-use gradient. Ecological Applications, 19(8), 2142-2156.

Kouki, J., Löfman, S., Martikainen, P., Rouvinen, S., \& Uotila, A. (2001). Forest fragmentation in Fennoscandia: linking habitat requirements of wood-associated threatened species to landscape and habitat changes. Scandinavian Journal of Forest Research, 16(S3), 27-37.

Kremen, C. (2005). Managing ecosystem services: what do we need to know about their ecology? Ecology Letters, 8(5), 468-479.

Lamoreux, J. F., Morrison, J. C., Ricketts, T. H., Olson, D. M., Dinerstein, E., McKnight, M. W., \& Shugart, H. H. (2006). Global tests of biodiversity concordance and the importance of endemism. Nature, 440(7081), 212-214.

Laurance, W. F. (1999). Reflections on the tropical deforestation crisis. Biological Conservation, 91(2), 109-117.

León-Yánez, S., R. Valencia, N. Pitman, L. Endara, C. Ulloa Ulloa \& H. Navarrete (eds.). (2011). Libro rojo de las plantas endémicas del Ecuador, $2^{a}$ edición. Publicaciones del Herbario QCA, Pontificia Universidad Católica del Ecuador, Quito.

Lessmann, J., Munoz, J., \& Bonaccorso, E. (2014). Maximizing species conservation in continental Ecuador: a case of systematic conservation planning for biodiverse regions. Ecology \& Evolution, 4(12), 2410-2422.

Linares-Palomino, R., \& Alvarez, S. I. P. (2005). Tree community patterns in seasonally dry tropical forests in the Cerros de Amotape Cordillera, Tumbes, Peru. Forest Ecology \& Management, 209(3), 261-272. 
Linares-Palomino, R., Kvist, L. P., Aguirre-Mendoza, Z., \& Gonzales-Inca, C. (2010). Diversity and endemism of woody plant species in the Equatorial Pacific seasonally dry forests. Biodiversity \& Conservation, 19(1), 169-185.

Loreau, M., Naeem, S., Inchausti, P., Bengtsson, J., Grime, J. P., Hector, A., \& Wardle, D. A. (2001). Biodiversity and ecosystem functioning: current knowledge and future challenges. Science, 294(5543), 804-808.

Maiorano, L., Falcucci, A., \& Boitani, L. (2006). Gap analysis of terrestrial vertebrates in Italy: priorities for conservation planning in a human dominated landscape. Biological Conservation, 133(4), 455-473.

Margules, C. R., \& Pressey, R. L. (2000). Systematic conservation planning. Nature, 405(6783), 243-253.

Margules, C. R., Pressey, R. L., \& Williams, P. H. (2002). Representing biodiversity: data and procedures for identifying priority areas for conservation. Journal of Biosciences, 27(4), 309-326.

Mateo, R. G., de la Estrella, M., Felicísimo, Á. M., Muñoz, J., \& Guisan, A. (2013). A new spin on a compositionalist predictive modelling framework for conservation planning: a tropical case study in Ecuador. Biological Conservation, 160, 150-161.

McKnight, M. W., White, P. S., McDonald, R. I., Lamoreux, J. F., Sechrest, W., Ridgely, R. S., \& Stuart, S. N. (2007). Putting beta-diversity on the map: broad-scale congruence and coincidence in the extremes. PLoS Biology, 5(10): e272.

Melo, A. S., Rangel, T. F. L., \& Diniz-Filho, J. A. F. (2009). Environmental drivers of beta-diversity patterns in New-World birds and mammals. Ecography, 32(2), 226-236.

Milne, D.J., Fisher, A., Pavey, C.R., (2006). Models of the habitat associations and distributions of insectivorous bats of the Top End of the Northern Territory, Australia. Biological Conservation 130, 370-385. 
Mittermeier, R. A., Myers, N., Thomsen, J. B., Da Fonseca, G. A., \& Olivieri, S. (1998). Biodiversity hotspots and major tropical wilderness areas: approaches to setting conservation priorities. Conservation Biology, 12(3), 516-520.

Myers, N. (1988). Threatened biotas:" hot spots" in tropical forests. Environmentalist, 8(3), 187-208.

Myers, N., Mittermeier, R. A., Mittermeier, C. G., Da Fonseca, G. A., \& Kent, J. (2000). Biodiversity hotspots for conservation priorities. Nature, 403(6772), 853-858.

Nagendra, H. (2008). Do parks work? Impact of protected areas on land cover clearing. AMBIO, 37(5), 330-337.

Naughton-Treves, L., Holland, M. B., \& Brandon, K. (2005). The role of protected areas in conserving biodiversity and sustaining local livelihoods. Annual Review of Environment \& Resources, 30, 219-252.

Neill, D. A. (2012). ¿Cuántas especies nativas de plantas vasculares hay en Ecuador? Revista amazónica: Ciencia \& Tecnología, 1(1), 70-83.

Orme, C. D. L., Davies, R. G., Burgess, M., Eigenbrod, F., Pickup, N., Olson, V. A., \& Owens, I. P. (2005). Global hotspots of species richness are not congruent with endemism or threat. Nature, 436(7053), 1016-1019.

Ortega-Huerta, M.A., \& Peterson, A.T. (2008). Modeling ecological niches and predicting geographic distributions: a test of six presence-only methods. Revista Mexicana de Biodiversidad, 79, 205-216.

Phillips, S. J., R. P. Anderson, \& Schapire, R. E. (2006). Maximum entropy modeling of species geographic distributions. Ecological Modelling, 190, 231-259.

Pimm, S. L., \& Gittleman, J. L. (1992). Biological diversity: where is it? Science, 255(5047), 940-940. 
Pressey, R. L. (1994). Ad hoc reservations: forward or backward steps in developing representative reserve systems? Conservation Biology, 8(3), 662-668.

Pressey, R. L. (2004). Conservation planning and biodiversity: assembling the best data for the job. Conservation Biology, 18(6), 1677-1681.

Pressey, R. L., Possingham, H. P., \& Margules, C. R. (1996). Optimality in reserve selection algorithms: when does it matter and how much? Biological Conservation, 76(3), 259-267.

Rodrigues, A. S., \& Brooks, T. M. (2007). Shortcuts for biodiversity conservation planning: the effectiveness of surrogates. Annual Review of Ecology, Evolution \& Systematics, 713-737.

Rubio-Salcedo, M., Martínez, I., Carreno, F., \& Escudero, A. (2013). Poor effectiveness of the Natura 2000 network protecting Mediterranean lichen species. Journal for Nature Conservation, 21(1), 1-9.

Sarkar, S., \& Illoldi-Rangel, P. (2010). Systematic conservation planning: an updated protocol. Natureza \& Conservação, 8(1), 19-26.

Sérgio, C., R. Figueira, D. Draper, R. Menezes, \& Sousa, J. (2007). The use of herbarium data for the assessment of red list categories: Modelling bryophyte distribution based on ecological information. Biological Conservation, 135, 341-351.

Sierra, R., Campos, F., \& Chamberlin, J. (2002). Assessing biodiversity conservation priorities: ecosystem risk and representativeness in continental Ecuador. Landscape \& Urban Planning, 59(2), 95-110.

Tapia-Armijos, M. F., Homeier, J., Espinosa, C. I., Leuschner, C., \& de la Cruz, M. (2015). Deforestation and Forest Fragmentation in South Ecuador since the 1970s-Losing a Hotspot of Biodiversity. PloS one, 10(9), e0133701.

Ter Steege, H., Sabatier, D., Castellanos, H., Van Andel, T., Duivenvoorden, J., Adalardo de Oliveira, A., \& Mori, S. (2000). An analysis of the floristic composition and 
diversity of Amazonian forests including those of the Guiana Shield. Journal of Tropical Ecology, 16(06), 801-828.

Tuomisto, H., \& Ruokolainen, K. (2005). Environmental heterogeneity and the diversity of pteridophytes and Melastomataceae in western Amazonia. Biol. Skr, 55, 37-56.

Tylianakis, J. M., Klein, A. M., \& Tscharntke, T. (2005). Spatiotemporal variation in the diversity of Hymenoptera across a tropical habitat gradient. Ecology, 86(12), 32963302.

Valencia, R., Foster, R. B., Villa, G., Condit, R., Svenning, J. C., Hernández, C., \& Balslev, H. (2004). Tree species distributions and local habitat variation in the Amazon: large forest plot in eastern Ecuador. Journal of Ecology, 92(2), 214-229.

Vamosi, J. C., \& Vamosi, S. M. (2008). Extinction risk escalates in the tropics. PLoS One, 3(12): e3886-e3886.

VanDerWal, J., Shoo, L.P., Graham, C., William, S.E., 2009. Selecting pseudo-absence data for presence-only distribution modeling: how far should you stray from what you know? Ecological Modelling, 220, 589-594.

Whittaker, R. H. (1972). Evolution and measurement of species diversity. Taxon, 213-251.

Wilson, K. A., Cabeza, M., \& Klein, C. J. (2009). Fundamental concepts of spatial conservation prioritization. Spatial Conservation Prioritization: Quantitative Methods and Computational Tools. Oxford University Press, New York, 16-27.

Zweig, M.H., Campbell, G., 1993. Reciever-operating characteristic (ROC) plots: a fundamental evaluation tool in clinical medicine. Clinical Chemistry, 39, 561-577 


\section{CHAPTER 5 \\ Synthesis}




\section{Synthesis}

The studies presented in the previous chapters of this dissertation contribute to a better understanding of the landscape dynamics and the biodiversity patterns in South Ecuador, an area understudied despite its high biodiversity and importance for conservation. The new data generated contribute valuable information to the process of conservation planning and decision making at local level.

\subsection{Summary of the major findings}

\subsubsection{Deforestation, fragmentation, and human pressure dynamics in South Ecuador}

The analysis of deforestation in South Ecuador revealed that almost $46 \%$ of the original natural cover disappeared since 1976 at annual deforestation rates of $0.75 \%$ for the period 1976-1989 and of $2.86 \%$ for the period 1989-2008, showing a marked increase of deforestation during the last twenty years. This makes South Ecuador one of the main actual fronts of deforestation in the country together with the northwestern coastal forests of Esmeraldas, Manabí and Guayas and the Northeastern Amazon forests of Sucumbíos; Orellana and Napo (Dodson and Gentry, 1991; Wunder, 2000; Pichón, 1997; Sierra, 2000; Messina et al., 2006; Rudel and Horowitz, 2013). In the region, the deforestation is mainly concentrated at low altitudes on both slopes of the Andes where the premontane evergreen

forest and the shrublands are the two vegetation types that exhibit the highest rates of conversion. Most of the human settlements and productive activities on the eastern Andean slope are located in the premontane evergreen forest close to main rivers and roads, indicating that accessibility is one of the main drivers of deforestation in this zone. In the case of the shrublands which are mainly located in the humid and dry inter-Andean valleys the patterns of deforestation are more diffuse, there the major activities date back to the colonial era. Although the rate of deforestation in the seasonally dry forest is less important compared with the other vegetation types, about $2 \%$ of the area of this forest disappeared every year since 1989. This is important to emphasize because the largest well-preserved remnants of dry forests in the country are located in South Ecuador (Espinosa et al., 2012). The forests of South Ecuador are being degraded and converted to pastures which is common all over the country, but particularly in this region most soils are of low fertility. 
Pastures are not very productive with the consequence that the forest is being cleared progressively (Homeier et al., 2013)

Like deforestation, the fragmentation process has also intensified dramatically in the region where the number of forest fragments has increased by $500 \%$ compared with the number of fragments registered in 1976. Actually, the regional landscape is characterized by few large fragments most of which are under some form of protection and many patches of less than $1 \mathrm{~km}^{2}$. In addition to the reduction of forests patches size, we also observed an increase of isolation between patches and a decrease in the regularity of patch shapes. The current composition and configuration of the South Ecuadorian landscape could have a direct influence on the landscape ecological functionality jeopardizing the availability viable populations, species richness and the high biodiversity that characterized this area (Fahrig, 2003; Hansen and DeFries, 2007; Knowlton and Graham, 2011).

Both processes, deforestation and fragmentation, are the result of human pressure on natural habitats. In South Ecuador, the levels of human pressure have increased since 1982, but the increase is more noticeable in the eastern part. This is because the eastern part of the Zamora-Chinchipe province was one of the least accessible and populated areas until the late 1960s when government policies promoted the colonization of new areas. Since then, human density and human activities have increased in this area. Despite this, it still has the largest wildest areas which are concentrated on the eastern escarpments of the Andes and in the lowlands at the border with Perú.

An important finding of this research is how human proxies differentially influence the natural vegetation types. For example, human density had the major contribution to the HF in all vegetation types with the exception of the Paramo, where land transformation was the predominant factor. As mentioned by Ellis \& Ramankutty (2008) to recognize the different patterns and drivers that promote transformation is essential to propose more effective conservation plans.

\subsubsection{Alpha and beta diversity of endemic plant species}

The highest alpha diversity of endemic plant species in Ecuador is concentrated in the Andes. This pattern has been associated with the increasing isolation and decreasing 
surface in mountain areas which promote higher speciation rates (Graves, 1988, Major, 1995). However, this pattern shows low concordance with the highest levels of beta diversity, which is concentrated in the western and eastern escarpments of the Andes but also in the Coastal and Amazonian cordilleras. Beta diversity patterns are related to medium and upper elevations, rough topography and biome boundaries (McKnight et al., 2007). In Ecuador, the high environmental heterogeneity promotes a high variation of ecological niches and therefore variation of plant species composition at short distances (Melo et al., 2009; Richter et al., 2009).

\subsection{Implication of the research findings in the context of conservation planning at regional and national level.}

This research has contributed to the conservation planning process at different scales. At national level, we have identified the areas with the highest importance for conservation of endemic plant species based on the alpha and beta diversity patterns. The results also show how threatened this group is. About the $40 \%$ of the surface identified with highest potential alpha and beta diversity of endemic plant species has disappeared. The more vulnerable population are those located west of the Andes where almost all the natural coastal vegetal formations have disappeared, or show at least some grade of intervention and only small portions are under conservation. A relatively good level of protection has been identified on the eastern slope of the Andes.

The major conservation gaps are in South of Ecuador where large areas with a high priority of conservation were identified, and the percentage of protected area is still low.

We also have shown the low concordance between alpha and beta diversity and the implications of this in the context of the prioritization of areas for conservation. Here we demonstrated that use only alpha diversity as a diversity indicator could produce an underrepresentation of unique assemblages of plant endemic species which are a key factor to maximize representativeness. 
At local level in South Ecuador, we have identified the dynamics of deforestation showing that conservation actions are urgent according to the high annual deforestation rates detected. Also, we have described the composition and configuration of remaining natural vegetation areas which allow identifying largest areas with potential for conservation in the PANE and also small areas of forest that must be included under other conservation figures (e.g. privately managed forests).

This information is complemented with the description of human pressure patterns through the use of the Human Footprint Index, developed by Sanderson et al. (2002) but tailored at local level. We have identified the wildest areas with high potential for conservation under PANE and areas with low and moderate human pressure levels that also could be considered to the implementation of other conservation forms. We emphasize the importance of considering patterns of human pressure as an indicator in the location of areas for conservation since their effectiveness is highly related to human influence in the surrounding landscape.

\subsection{Propose of new areas of conservation for South Ecuador}




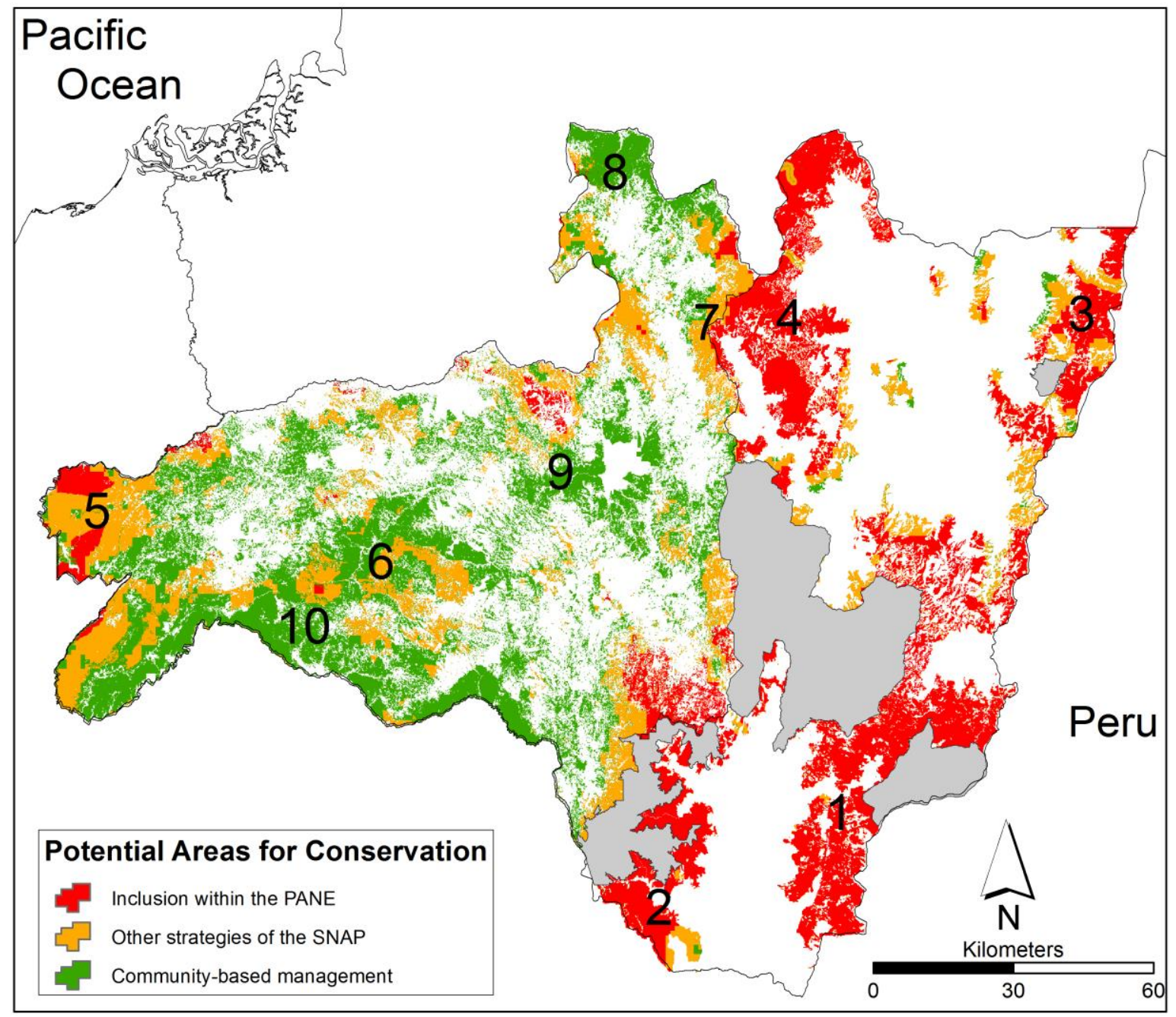

Figure 5.1 Potential areas for conservation in South Ecuador based on Human Footprint levels, diversity patterns of endemic plants and remaining forest. 1 South part of Podocapus National Park. 2 Surrounding areas of Yacuri National Park. 3 Cóndor Cordillera. 4 Yacuambi. 5 Seasonally dry forest around Cazaderos. 6 Lowest part of Pindal. 7 Montane forest at East part of Saraguro. 8 Montane forest at North part of Saraguro. 9 Dry shrubland of Catamayo. 10 Seasonally dry forest of Macará.

\subsection{Limitation of this research and future perspectives}

The results in the different chapters of this dissertation add new information relation to the poor spatial information so far available for Ecuador, especially for South Ecuador. However, additional studies are needed to understand better how the environmental 
conditions or territorial dynamics influence the persistence of biodiversity in the long term. For example, we need to understand how the highly fragmented landscape observed in South Ecuador is influencing the population dynamics of endemic plant species. Here we describe the patterns of alpha and beta diversity, but it is necessary to generate more information about the factors that are affecting each of these patterns.

There is information about factors that promote alpha diversity in many taxa but information about factors promoting beta diversity patterns is still insufficient. Also, more research about the concordance of alpha and beta diversity patterns in different taxa would be helpful to understand the potential of using biodiversity surrogates (e.g. endemic plant species).

It is important to remark that a lot of spatial information has been generated that is going to be used in further analyses:

- To understand how climate change is going to influence the patterns of alpha and beta diversity the existing species distribution models could be updated with different projected climate scenarios.

- To describe the proximate and underlying causes of deforestation.

\subsection{References}

Dodson, C. H., \& Gentry, A. H. (1991). Biological extinction in western Ecuador. Annals of the Missouri Botanical Garden, 273-295.

Ellis, E. C., \& Ramankutty, N. (2008). Putting people in the map: anthropogenic biomes of the world. Frontiers in Ecology \& the Environment, 6(8), 439-447.

Espinosa, C. I., De la Cruz, M., Luzuriaga, A. L., \& Escudero, A. (2012). Bosques tropicales secos de la región Pacífico Ecuatorial: diversidad, estructura, funcionamiento e implicaciones para la conservación. Revista Ecosistemas, 21(1-2). 
Fahrig, L. (2003). Effects of habitat fragmentation on biodiversity. Annual Review of Ecology, Evolution \& Systematics, 34, 487-515.

Graves, G. R. (1988). Linearity of geographic range and its possible effect on the population structure of Andean birds. The Auk, 47-52.

Hansen, A. J., \& DeFries, R. (2007). Ecological mechanisms linking protected areas to surrounding lands. Ecological Applications, 17(4), 974-988.

Homeier, J., Werner, F. A., Gawlik, J., Peters, T., Diertl, K. H. J., \& Richter, M. (2013). Plant Diversity and Its Relevance for the Provision of Ecosystem Services. In Ecosystem Services, Biodiversity and Environmental Change in a Tropical Mountain Ecosystem of South Ecuador (pp. 93-106). Springer Berlin Heidelberg.

Knowlton, J. L., \& Graham, C. H. (2011). Species interactions are disrupted by habitat degradation in the highly threatened Tumbesian region of Ecuador. Ecological Applications, 21(8), 2974-2986.

Major, J. (1988). Endemism: a botanical perspective. In Analytical biogeography (pp. 117146). Springer Netherlands.

McKnight, M. W., White, P. S., McDonald, R. I., Lamoreux, J. F., Sechrest, W., Ridgely, R. S., \& Stuart, S. N. (2007). Putting beta-diversity on the map: broad-scale congruence and coincidence in the extremes. PLoS Biology, 5(10): e272.

Melo, A. S., Rangel, T. F. L., \& Diniz-Filho, J. A. F. (2009). Environmental drivers of beta-diversity patterns in New-World birds and mammals. Ecography, 32(2), 226-236.

Messina, J. P., Walsh, S. J., Mena, C. F., \& Delamater, P. L. (2006). Land tenure and deforestation patterns in the Ecuadorian Amazon: Conflicts in land conservation in frontier settings. Applied Geography, 26(2), 113-128.

Pichón, F. J. (1997). Colonist land-allocation decisions, land use, and deforestation in the Ecuadorian Amazon frontier. Economic Development \& Cultural Change, 45(4), 707744. 
Richter, M., Diertl, K. H., Emck, P., Peters, T., \& Beck, E. (2009). Reasons for an outstanding plant diversity in the tropical Andes of Southern Ecuador. Landscape Online, 12(2009), 1-35.

Rudel, T. A., \& Horowitz, B. (2013). Tropical Deforestation: Small Farmers and Land Clearing in Ecuadorian Amazon. Columbia University Press.

Sanderson, E. W., Jaiteh, M., Levy, M. A., Redford, K. H., Wannebo, A. V., \& Woolmer, G. (2002). The Human Footprint and the Last of the Wild: the human footprint is a global map of human influence on the land surface, which suggests that human beings are stewards of nature, whether we like it or not. BioScience, 52(10), 891-904.

Sierra, R. (2000). Dynamics and patterns of deforestation in the western Amazon: the Napo deforestation front, 1986-1996. Applied Geography, 20(1), 1-16.

Wunder, S. (2000). The economics of deforestation: The example of Ecuador. Macmillan, Houndmills. 